\title{
Relación entre estructura y función de la perivitelina PV2 de Pomacea canaliculata
}

\section{(Gastropoda: Ampullariidae)}

María Victoria Frassa

Director: Horacio Heras

Codirector: Marcelo Ceolín

Facultad de Ciencias Naturales y Museo Universidad Nacional de La Plata 


\section{"La ciencia es una estrategia \\ es una forma de atar la verdad es algo mas que materia pues el milagro se oculta detrás"}


A mis padres,

hermanos,

Gonzalo

y mi futuro sobrino 


\section{Agradecimientos}

Lo que significa la tesis para mí más allá de la culminación de una etapa académica es un paso más en mi vida, un objetivo alcanzado, un logro profesional y personal.

Es mérito de toda la gente que me acompañó en esta etapa y también de mi esfuerzo. Quiero agradecerles a todos.

A mis amigos y familia que siempre fueron mi refugio, alentándome y dándome confianza en mí misma.

Al INIFTA por brindarme las instalaciones para realizar esta tesis

A todo el INIBIOLP, por ser mi hogar adoptivo en esta tesis, por darme la contención necesaria y por permitirme conocer excelentes personas.

A Horacio por su gran apoyo, confianza, contención, calidad humana y los importantes aportes que realizó para que pudiera culminar esta tesis.

A Marcelo por su sensatez y ayuda en el mundo de la biofísica completamente desconocido por mí en aquel momento.

A Marcos por explicarme desde un principio a "trabajar en la mesada", por su aliento y preocupación en momentos difíciles.

A todo el laboratorio 8 bis: Moni, Marcos, Sabri, Fer, Santi, Horacio, Yan y Aldi gracias por las charlas de desahogo, mates, ayuda y amistad en tantos momentos, por soportar mis cambios de ánimo que fueron muuuuuuuuchos y por darme aliento para no caer en las frustraciones. 
A los chicos del altillo: Mauro, Tati y Nico por la valiosa ayuda y paciencia en mis inexpertos pasos por la Biología Molecular.

Al laboratorio 7, por mates, alguna cosita dulce y ayuda siempre que la necesité

A Patricia y Eduardo por su calidez y ayuda en Patología.

A los chicos de Bahía Blanca por las muestras y por su buena onda y compañerismo.

A mis padres por el incondicional amor y apoyo de siempre, simplemente por ser mi sostén.

A mis hermanos que adoro y me enorgullecen de la familia que tengo.

A Gonzalo por su amor, contención y paciencia extrema en este tiempo de grandes incertidumbres e inseguridades.

A mis amigas de la vida por estar presentes cada una de distintas maneras, desde la que me pudo ayudar con temas concretos aunque sea a la distancia hasta aquellas que simplemente me preguntaban y? como va ese ....... caracol?.

A mis amigas Aldi, Yani, Angelita por tantas horas compartidas que se hicieron más amena con ustedes.

Y por último a un ser no viviente pero que transitó la mayor cantidad de horas y frustraciones conmigo, el HPLC que llegué a odiar cuando veía sus cromatogramas pero prometí que iba a tener un lugar aunque nunca se entere... y eso que casi logro hacerlo hablar!! 


\section{INDICE}

Lista de abreviaturas y símbolos

Resumen

iii

Abstract

vii

\section{CAPÍTULO 1: Introducción general}

1.1 Modelo biológico: Pomacea canaliculata

1.1.1 Características generales. Ubicación taxonómica

1.1.2 Distribución geográfica-hábitat

1.1.3 Aspectos ecológicos

1.1.4 Importancia económico-sanitaria

1.2 Biología reproductiva

1.2.1 Estrategias reproductivas y de oviposición

1.2.2 Fluido perivitelino. Componentes y funciones

1.2.3 Perivitelinas de Pomacea canaliculata

CAPÍTULO 2: Objetivos

\section{CAPÍTULO 3: Metodología}

3.1 Aislamiento de las perivitelinas de P. canaliculata

3.1.1 Recolección de las muestras

3.1.2 Obtención de la fracción soluble de los huevos

3.1.3 Aislamiento y purificación de perivitelinas

3.2 Cuantificación de proteínas totales

3.3 Electroforesis en geles de poliacrilamida

- Electroforesis en geles en gradiente de poliacrilamida 
en condiciones nativas (PAGGE)

- Electroforesis en condiciones desnaturalizantes: SDS-

PAGGE

- Electroforesis bidimensional (2-DE)

3.4 Detección (western bloty dot blot) y cuantificación (ELISA) de las perivitelinas

3.4.1 Anticuerpos utilizados

3.4.2 Western blot

3.4.3 Dot blot

3.4.4 ELISA (Prueba de inmunoensayo ligado a enzimas)

3.5 Técnicas de biología molecular

3.5.1 Cepas bacterianas y medios de cultivo

3.5.2 Extracción de ARN

3.5.3 Electroforesis en gel desnaturalizante de ARN

3.5.4 Transcripción reversa (RT) 30

3.5.5 Diseño de primers degenerados

3.5.6 Reacción en cadena de la polimerasa (PCR) 32

3.5.7 Electroforesis en geles de agarosa 32

3.5.8 Aislamiento y purificación de fragmentos de PCR 33

3.5.9 Amplificación rápida de extremos de ADNc (RACE) 35

3.6 Técnicas aplicadas a los estudios biofísicos

3.6.1 Espectroscopía de absorción UV

3.6.2 Espectroscopía de fluorescencia

- Fundamentos generales

- Fluorescencia de proteínas

- Quenching de fluorescencia

- Cuantificación de cisteínas

3.6.3 Dicroísmo circular de luz UV (CD)

3.6.4 Dispersión de rayos $X$ a bajo ángulo (SAXS) 
3.6.5 Microscopía electrónica de transmisión (MET) 44

3.6.6 Digestión con proteinasa K 45

3.7 Ensayos de toxicidad

3.7.1 Determinación de LD50 en ratones 46

3.7.2 Ensayo de toxicidad de lípidos 46

3.7.3 Determinación de la susceptibilidad térmica 47

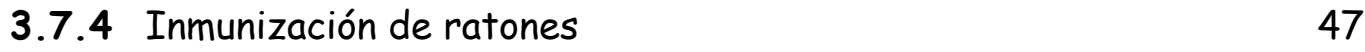

3.7.5 Histopatología 47

$\begin{array}{lll}3.7 .6 & \text { Inmunohistoquímica } & 48\end{array}$

3.7.7 Ensayos electrofisiológicos 49

3.8 Digestión gastrointestinal simulada 50

3.9 Efecto de la alimentación y esfuerzo reproductivo en la calidad de huevos

3.9.1 Cría de P. canaliculata en laboratorio. Condiciones de alimentación

3.9.2 Medidas de reflectancia de huevos 52

3.9.3 Determinación de galactógeno 52

\section{CAPÍTULO 4: Estructura}

4.1 Introducción 53

4.2 Caracterización estructural 54

4.3 Estructura secundaria 55

4.4 Estructura terciaria y cuaternaria 56

4.5 Estructura primaria de la subunidad menor de PV2 63

4.6 Análisis bioinformático de la subunidad menor de PV2 67

$\begin{array}{lll}4.7 & \text { Discusión } & 70\end{array}$

\section{CAPÍTULO 5: Estabilidad}

$\begin{array}{lll}5.1 & \text { Introducción } & 74\end{array}$

5.2 Estabilidad frente a la acción de la urea 76 
5.3 Estudios de estabilidad térmica 79

5.4 Efecto del pH sobre PV2 82

5.5 Susceptibilidad de PV2 frente a la proteinasa K 85

$\mathbf{5 . 6}$ Discusión 85

\section{Capítulo 6: Funciones}

6.1 Introducción

6.2 Efectos tóxicos de los componentes del huevo

6.2.1 Extractos de huevos en adultos de la misma especie 90

6.2.2 Extractos de huevos en ratones y renacuajos 90

6.2.3 Identificación de la fracción tóxica: PV2 91

6.2.4 Caracterización de la actividad tóxica de PV2 91

6.2.5 Sintomatología del modelo murino intoxicado 93

6.2.6 Efecto sobre diferentes órganos de ratón 94

6.2.7 Efecto sobre el SNC (metabolismo del calcio y apoptosis) 95

6.2.8 Ensayos electrofisiológicos 97

6.3 Resistencia a digestión gastrointestinal 97

6.3.1 Digestión in vitro 97

6.3.2 Efecto de la administración oral a ratas 99

6.4 Discusión 101

Capitulo 7: Efecto de la dieta y esfuerzo reproductivo sobre la toxicidad y calidad de los huevos

7.1 Introducción

7.2 Efecto sobre la coloración

7.3 Efecto sobre la cantidad y tamaño de puestas

7.4 Efecto sobre las defensas bioquímicas

7.5 Efecto sobre la energética del huevo 
CAPÍTULO 8: Conclusiones 


\section{Abreviaturas}

A: Longitud de onda

$\delta:$ Densidad

2-DE: Electroforesis bidimensional

A: Absorbancia

$A_{260}$ : Absorbancia a $260 \mathrm{~nm}$

$A_{280}$ : Absorbancia a $280 \mathrm{~nm}$

A $1^{\circ}$ : Anticuerpo primario

A 20: Anticuerpo secundario

ADNc: $A D N$ complementario

$\beta$-ME: $\beta$-mercaptoetanol

BSA: Albúmina sérica bovina

CD: Dicroísmo circular

DEPC: Dietil-pirocarbonato

fCD: Dicroísmo circular en UV lejano

FPV: Fluido perivitelino

HE: Hematoxilina-eosina

HPLC: Cromatografía líquida de alta presión

IEF: Enfoque isoeléctrico

IHQ: Inmuno histoquímica

i.p.: Intraperitoneal

IPG: Gradientes de $\mathrm{pH}$ inmovilizados

LB: Medio Luria Bertani

LD100: Dosis letal 100

LD50: Dosis letal 50

MET: Microscopía electrónica de transmisión

nCD: Dicroísmo circular en UV cercano

$N$ t: $N_{\text {terminal }}$

OR=PV1: Ovorrubina, perivitelina 1 
PAGE: Electroforesis en geles de poliacrilamida en condiciones nativas

PAGGE: Electroforesis en geles en gradiente de poliacrilamida en condiciones nativas

pb: Pares de bases

PBS: Buffer fosfato salino

PBST: Buffer fosfato salino con Tween 20

PCR: Reacción en cadena de la polimerasa

Phe: fenilalanina

Pi: Buffer fosfato

pI: Punto isoeléctrico

PM: Peso molecular

$P(R):$ Pares de distancia

PV2: Perivitelina 2

PV3: Perivitelina 3

RACE: Amplificación rápida de extremos de ADNC

$\mathbf{R}_{G}:$ Radio de giro

RT: Transcripción reversa

SAXS: Dispersión de rayos $X$ a bajo ángulo

SDS: Dodecil sulfato sódico

SDS PAGGE: Electroforesis en geles en gradiente de poliacrilamida en condiciones desnaturalizantes

SDS PAGE: Electroforesis en geles de poliacrilamida en condiciones desnaturalizantes

S-S: disulfuro

Tm: Temperatura de melting

Trp: Triptofano

TTX: Tetrodotoxina

Tyr: Tirosina

VHDL: Proteína de muy alta densidad

WB: Western blot 


\section{Resumen}

El caracol dulceacuícola Pomacea canaliculata es nativo de Sudamérica y, además de ser biológicamente muy interesante, presenta especial interés económico-sanitario por ser plaga en numerosos cultivos, especialmente arroz, y también presenta importancia epidemiológica porque es hospedador intermediario del nematode causante de la meningoencefalitis eosinofílica humana.

Las hembras oviponen fuera del agua y estas puestas aéreas quedan expuestas a un ambiente agresivo de alta radiación solar, temperatura y depredadores terrestres. A pesar de ello, los huevos eclosionan normalmente, y contrariamente a lo esperable, se registran muy pocos casos de depredación en condiciones naturales, restringida solo a la "hormiga de fuego" (Solenopsis geminata). Este hecho llevó a suponer la existencia en el huevo de algún sistema de protección, relacionado con la coloración rosada muy llamativa que presenta, considerada de advertencia (aposemática), si bien al comienzo de esta tesis no existían antecedentes de la naturaleza de sus defensas.

Los huevos de P. canaliculata están provistos de un fluido perivitelino (FPV) que es secretado por la glándula del albumen de la hembra. EI FPV actúa como una fuente energética, estructural y supuestamente también de defensa para el embrión. Su composición bioquímica está dominada principalmente por hidratos de carbono, lípidos y por proteínas denominadas perivitelinas, en particular ovorrubina (OR) un inhibidor de proteasas, y las perivitelinas PV2 y PV3. La PV2 es una glicolipoproteína de 400 kDa y dos subunidades de 67 y 31 kDa. Hasta el momento de este estudio, la única función descripta para estas perivitelinas era la de proveer de nutrientes al embrión durante su desarrollo.

En el presente trabajo se buscó ampliar el conocimiento de la biología reproductiva de este caracol, tratando de identificar cuál era la defensa del huevo tan llamativamente señalada, enfocando el estudio en la perivitelina PV2. En una primera etapa, se la caracterizó estructuralmente y luego se estudiaron las funciones que cumplía en los huevos de P. canaliculata. Finalmente, se analizó si el nivel de defensa bioquímica del huevo estaba relacionado con la intensidad de su color rojo, y si éste variaba a lo largo de la estación reproductiva y con respecto a la alimentación. 
Se comenzó el estudio analizando las características estructurales y la conformación que adopta en el espacio la PV2, empleando técnicas tales como: emisión de fluorescencia de Trp, dispersión de rayos $X$ a bajo ángulo (SAXS), dicroísmo circular y microscopía electrónica. Los resultados mostraron que es una proteína globular y anisométrica de $44 \times 130 \AA$. Los datos de SAXS permitieron lograr un modelo tridimensional de baja resolución de la proteína en solución que resultó coincidente con datos obtenidos mediante microscopía electrónica. Se demostró luego que PV2 es un octámero compacto y bien plegado, que forma cuatro heterodímeros de 98 kDa, cada uno estabilizado por puentes disulfuro intercatenarios. El oligómero presenta un punto isoeléctrico de 6,2.

La subunidad menor de $31 \mathrm{kDa}$ exhibe varias isoformas que podrían deberse a modificaciones postraduccionales. Mediante técnicas de biología molecular se secuenció la subunidad menor completa a partir de ADNc de la glándula del albumen. El análisis con herramientas bioinformáticas mostró que presenta homología con las lectinas del tipo taquilectina de otros invertebrados.

Debido a que la estabilidad estructural de las proteínas es clave para interpretar su funcionamiento, se investigó el efecto de la temperatura, el pH y agentes químicos para inducir la desnaturalización de PV2. En esta partícula, el estudio de la termoestabilidad presenta un valor añadido porque los huevos deben soportar altas temperaturas y radiación solar directa. Los resultados mostraron que presenta una elevada termoestabilidad (hasta $60^{\circ} \mathrm{C}$ ) y es estable en un amplio rango de $\mathrm{pH}$ (4-10), mientras que la estructura terciaria se pierde casi por completo a una concentración de $6 \mathrm{M}$ urea. Se completaron los estudios de estabilidad evaluando la susceptibilidad a la proteólisis, el cual mostró que la subunidad menor es más resistente al ataque proteolítico inespecífico de proteinasa $K$, probablemente debido a que esté menos expuesta.

Considerando su alta estabilidad frente al pH y para comprender la manera de incorporación de la proteína al predador que ingiriese los huevos, se estudió su resistencia a la digestión. Primeramente se usó un modelo de digestión in vitro que imita el paso de los alimentos a través del estómago y duodeno, evaluando la susceptibilidad de PV2 a la proteólisis gastrointestinal simulada. La perivitelina mostró ser resistente a la 
pepsinólisis y posterior tripsinólisis, tanto en condiciones nativas como disociantes, indicando que sería antinutritiva.

La identificación de las defensas del embrión comenzó utilizando la fracción soluble completa de huevo para realizar bioensayos en ratones Balb-C (Mus musculus) y en renacuajos de rana toro (Lithobates catesbeianus). Sorpresivamente la inyección de pequeñas cantidades produjo la muerte de ambas especies, por ello, se analizó la toxicidad de cada uno de sus componentes. Se pudo demostrar que los extractos lipídicos no mostraron ningún tipo de afección, mientras que entre las fracciones proteicas, la PV2 resultó altamente tóxica, termolábil e inmunogénica tanto por administración intraperitoneal como por vía oral, confirmando la naturaleza proteica del tóxico. Dosis subletales de PV2 por vía i.p. provocan respuesta inmunogénica en ratones hacia/para ambas subunidades, mientras que la inmunización oral fue notablemente específica hacia la subunidad mayor de la PV2.

La toxina en el modelo murino provocó sintomatología muy característica, que se inició con taquipnea, debilidad, abducción extrema de miembros posteriores y movimientos espásticos de la cola. Posteriormente los ratones mostraron paraplejía flácida con miembros posteriores completamente extendidos, mientras que los anteriores seguían siendo funcionales, llevando finalmente a la muerte en unas $30 \mathrm{~h}$.

El análisis histológico de los órganos extraídos de animales intoxicados mostró que la médula espinal es el único órgano blanco de la toxina. Además, los experimentos de electrofisiología en el músculo sartorio de la rana Leptodactylus ocellatus indicaron que ni la fracción soluble de huevos ni sus proteínas purificadas (OR, PV2 y PV3) afectaron la actividad eléctrica de las fibras musculares ni los elementos contráctiles, confirmando de esta manera que la afección era a nivel del sistema nervioso y no de las placas motoras.

Por ello, se focalizó el estudio en la médula en las regiones cervical, torácica y lumbar. Mediante inmunohistoquímica contra una proteína de unión al $\mathrm{Ca}^{+2}$ (calbindina) se observó expresión muy localizada de la calbindina a nivel de las láminas II y III del asta dorsal de la sustancia gris de animales controles, a diferencia de los inoculados donde la inmunomarcación fue prácticamente negativa. Al mismo tiempo, la misma población neuronal donde se registró la reducción de expresión de calbindina (láminas II y III) 
mostró muerte celular apoptótica, revelada mediante la técnica TUNEL.

Por último, se evaluó si la dieta y el esfuerzo reproductivo tenían algún efecto sobre la toxicidad, calidad de los huevos y coloración de advertencia. No se encontraron diferencias en la calidad, salvo una disminución significativa del peso promedio de las puestas en las hembras menos alimentadas. La concentración de las perivitelinas mayoritarias (OR, PV2) como la intensidad del color (medido por reflectancia) no mostraron cambios significativos. De la misma manera la inversión en galactógeno, principal reserva energética de los huevos, se mantuvo constante independientemente de la estación reproductiva o alimentación recibida.

En síntesis, en este trabajo se reporta por primera vez la presencia de una neurotoxina de origen proteico en huevos, y la primera información de la presencia de una neurotoxina en moluscos de agua dulce, aportando además, las primeras aproximaciones de su mecanismo de acción. Asimismo, su organización estructural y estabilidad frente al $\mathrm{pH}$ y digestión gastrointestinal simulada indican que es una proteína antinutritiva (indigestible) que llegaría activa al intestino para su absorción. La presencia de anticuerpos circulantes luego de la administración oral confirmaría el ingreso biológicamente activo a la circulación del depredador.

La toxicidad y color de los huevos no varían a lo largo de una estación reproductiva ni bajo diferentes condiciones tróficas de las hembras, en condiciones experimentales controladas.

Teniendo en cuenta las nuevas funciones encontradas para PV2 como proteína neurotóxica y antinutritiva, y sumando a estas las características de $O R$, de otorgar coloración aposemática, ser antidigestiva (inhibidor de proteasas), antinutritiva, y de aportar moléculas antioxidantes y de fotoprotección al embrión en sus primeras etapas de desarrollo, creemos que estas perivitelinas actuarían en forma conjunta y sinérgica como parte de una compleja defensa para los embriones que impediría la adquisición de nutrientes e intoxicaría al depredador.

La eficiencia de este mecanismo defensivo les permite además, sobrevivir bajo condiciones ambientales hostiles, un mecanismo complejo nunca antes descripto para el reino animal. 


\section{Abstract}

The freshwater snail Pomacea canaliculata is native from South America. It holds biological, economical and health interest. It is an important pest of many crops, especially rice and also presenting epidemiological importance because it can be an intermediate host of the nematode that causes human eosinophilic meningoencephalitis.

Females spawn above the waterline and these aerial egg clutches are exposed to an aggressive environment of high solar radiation, temperature and terrestrial predators. However, the eggs hatch normally and unexpectedly there are virtually no predators in natural conditions, except for the "fire ant" (Solenopsis geminata). This fact led to assume the existence of a defense system in the eggs, advertised by the presence of the striking pink colour of clutches. This colouration was considered a warning signal (aposematic), although at the beginning of this Ph.D Thesis the nature of their defenses was unknown.

The eggs of $P$. canaliculata contain a perivitellin fluid (PVF), which is secreted by the albumen gland of the female. The PVF acts as an energy and structural source, and also as a putative defense system for the embryo. Its biochemical composition is dominated by carbohydrates, lipids and proteins called perivitellins, particularly ovorubin $(O R)$ a protease inhibitor, and the perivitellins PV2 and PV3. The PV2 is a glycolipoprotein with a molecular weight of $400 \mathrm{kDa}$ and two subunits of 67 and $31 \mathrm{kDa}$. Until this study, the only function described for these perivitellins was to provide nutrients to the embryo during its development.

The present study provides new information about the reproductive biology of this snail, trying to identify the biochemical defense of the eggs, focusing on the study of the perivitellin PV2. First the structure and functions of the protein in the eggs of $P$. canaliculata were characterized. Finally, we analyze if the level of biochemical egg defense was related to the intensity of the aposematic coloration, the variations across the breeding season and feeding were recorded.

We began studying the structural features and the conformation that PV2 adopts in space, analized using biophysical techniques such as Trp fluorescence emission, small 
angle X-ray scattering (SAXS), circular dichroism and electron microscopy. The results showed that it is a globular and anisometric protein with a gyration radius of $44 \times 130 \AA$. SAXS data allowed to obtain a low-resolution three-dimensional model of the protein in solution that was coincident with the electron microscopy data. In addition, it was determined that PV2 is a compact, well folded octamer composed of 4 heterodimers of $98 \mathrm{kDa}$, each one stabilized by interchain disulfide bonds. The oligomer has an isoelectric point of 6,2 .

The small subunit of $31 \mathrm{kDa}$ shows several isoforms probably due to posttranslational modifications. The full CDNA sequence of the small subunit was obtained from the albumen gland, using molecular biology techniques. Bioinformatic analysis showed that PV2 presents homology with lectins of the tachylectin type of other invertebrates.

Considering that the structural stability of proteins is the key to understand its functions, we investigated the effect of temperature, $\mathrm{pH}$ and chemical denaturants to induce denaturation of PV2. In this particle, the study of thermostability has an added value because the eggs must tolerate high temperatures and direct solar radiation. The results indicate that it has a high thermostability (up to $60^{\circ} \mathrm{C}$ ) and it is stable in a wide range of $\mathrm{pH}$ values (4-10), while the tertiary structure is completely lost at $6 \mathrm{M}$ urea. We completed the stability studies evaluating the susceptibility to proteolysis, which showed that the small subunit is more resistant to the nonspecific proteolytic attack with proteinase $K$, probably because it is less exposed.

To understand how the neurotoxin was incorporated into the predators eating eggs and considering the stability of PV2 to a wide range of $\mathrm{pH}$, its resistance to digestion was studied. Using an in vitro digestion model mimicking the movement of food through the stomach and duodenum, the susceptibility of PV2 to gastrointestinal proteolysis was evaluated. The perivitellin showed resistance to both pepsinolysis and trypsinolysis under native and dissociating conditions, strongly suggesting that it is anti-nutritional.

The identification of embryo defenses was initiated using egg soluble fraction bioassayed in Balb-C mice (Mus musculus) and bullfrog tadpoles (Lithobates 
catesbeianus). Surprisingly, the injection of small amounts of egg soluble fraction was lethal to both species so the possible toxicity of its components was analyzed.

We found that lipid extracts did not excert any kind of affection, while among the protein fractions, the PV2 was highly toxic, thermolabile and immunogenic by both intraperitoneal and oral administration, thus confirming the proteinaceous nature of the toxic. Injection of sublethal doses of PV2 caused immunogenic response in mice against both subunits, while oral immunization was specific only for the largest subunit.

The toxin caused very characteristic symptoms in the murine model, starting with tachypnea, weakness, extreme abduction of the rear limbs and spastic movements of the tail. Subsequently the mice showed flaccid paraplegia, with rear limbs fully extended while the forelimbs remained functional, leading to death in about $30 \mathrm{~h}$.

The organs removed from intoxicated animals were analyzed by histological techniques and the only target for the toxin was the spinal cord. In addition, experiments performed with the sartorius muscle of the frog Leptodactylus ocellatus indicated that the electrical activity of muscle fibers and the contractile elements of muscle were not affected by the soluble fraction of eggs or their purified proteins (OR, PV2 and PV3), confirming that the effect of the toxin was only in the nervous system. Therefore, we focused on spinal cord analyzing the cervical, thoracic and lumbar regions by immunohistochemistry against a $\mathrm{Ca}^{+2}$-binding protein (calbindin). The results indicated a highly localized expression for calbindin restricted to the laminae II and III of the dorsal horn of the gray matter in the control animals, opposite to the inoculated animals in which the immunostaining was virtually negative. Remarkably, the same neuronal population showing a reduced expression of calbindin also had apoptotic neurons as revealed by TUNEL staining.

Finally, the effect of the diet and reproductive effort on toxicity, quality of eggs and warning coloration was evaluated. No difference in egg quality was observed, though the average weight of egg clutches was significantly higher in well nourished females. The concentration of the major perivitellins (OR, PV2) and color intensity (measured by reflectance) showed no significant changes. Likewise, galactogen investment, the main 
energy reserve of eggs, remained constant regardless of the breeding season or received feeding.

In summary, this study reports for the first time a neurotoxic protein in eggs and the first information of a neurotoxin in freshwater mollusks, providing also the first insight of its mechanism of action. Furthermore, its structural organization, stability to $\mathrm{pH}$ and simulated gastrointestinal digestion indicate that PV2 would be an anti-nutritional protein (indigestible), that reach the intestine for absortion in a biologically active form. This fact agrees with the later presence of circulating antibodies after oral administration, indicating the intake in a biologically active protein into potential predators. The toxicity of eggs and aposematic signal does not vary neither throughout a breeding season nor under different trophic conditions of females, at least in controlled experimental conditions.

These new features found for PV2 as neurotoxic and anti-nutritional protein, can now be added to the features of $O R$ providing eggs with aposematic coloration, antidigestive (protease inhibitor), anti-nutritional, and antioxidants and photoprotection molecules to the embryo. Integrating all these novel functions, we believe these perivitellins act together and synergistically as part of a complex defense of the embryos, that would prevent the acquisition of nutrients and intoxicate the predator. This very efficient mechanism would protect eggs from both predators and harsh environmental conditions for its development, and represents, to our knowledge, a mechanism never described in the animal kingdom. 
CAPITULO 1

Introducción general 


\section{CAPÍTULO 1: Introducción general}

\subsection{Modelo biológico: Pomacea canaliculata}

\subsubsection{Características generales. Ubicación taxonómica}

Los gasterópodos son el grupo de moluscos más diverso. En Argentina se citan 101 especies de gasterópodos de agua dulce, siendo Ampullariidae una de las familias más representadas de Caenogastropoda (Cuezzo, 2009).

La familia Ampullariidae pertenece al clado Caenogastropoda (Bouchet \& Rocroi, 2005), con un registro fósil de 150 millones de años, originaria de la región del supercontinente Gondwana que en el presente corresponde a África (Hayes et al., 2009). Actualmente comprende nueve géneros con más de 150 especies y se distribuye sobre todo en hábitats húmedos tropicales y subtropicales de África, América del Sur y Central, y sudeste de Asia, incluyendo a los caracoles de agua dulce más grandes y alcanzando su mayor diversidad de especies en América del Sur (Cowie, 2002).

El ampulárido Pomacea canaliculata (Lamarck, 1822) fue seleccionado como modelo de estudio por ser de fácil acceso en cuerpos de agua cercanos, presentar puestas abundantes y de tamaño considerable disponibles durante siete meses al año y por poseer el mayor volumen de conocimiento científico dentro de las especies de la familia.

Este caracol, nativo de Sudamérica, presenta una conchilla globosa a subglobosa de color marrón con bandas espirales oscuras y líneas de crecimiento transversas. La presencia de manera simultánea de un pulmón y una branquia permite a estos caracoles mantener una respiración anfibia.

Es una especie ovípara con cópulas que duran entre 4 y 20 h y una singular conducta sexual que incluye ofrendas nupciales de los machos, no descriptas en otros gasterópodos (Burela \& Martín, 2007). Presentan dimorfismo sexual en la 
forma, tamaño y patrón de crecimiento de la conchilla, siendo las hembras las que alcanzan las mayores tallas en una población (Estebenet, 1998, Estebenet et al., 2006, Estebenet \& Martín, 2002, Estebenet \& Cazzaniga, 1998). El tamaño de los machos no parece relacionarse con su éxito copulatorio (Estebenet \& Martín, 2002), mientras que el de las hembras se correlaciona positivamente tanto con su fecundidad como con el tamaño de los caracoles al momento del nacimiento (Estebenet \& Cazzaniga, 1993, Martín \& Estebenet, 2002).

El sistema reproductor de las hembras consiste en un ovario impar en asociación con la glándula digestiva, un oviducto visceral y un oviducto paleal (Catalán et al., 2002). El oviducto paleal o útero está constituido por el receptáculo seminal, bolsa copulatriz y el complejo glándula del albumen-glándula de la cáscara.

Para producir una célula huevo (cigota), los óvulos son llevados desde el ovario hasta el receptáculo seminal donde tiene lugar la fertilización. El complejo glándula del albumen-glándula de la cáscara, que almacena grandes cantidades de $\mathrm{CaCO}_{3}$, es el encargado de proveer a los ovocitos de reservas nutricias y envolturas protectoras (Catalán et al., 2002, 2006). Para ello, primeramente rodea al ovocito de una sustancia viscosa llamada "fluido perivitelino" (FPV) y luego lo va recubriendo de una secreción mucoproteica hasta finalizar con la cápsula, que se endurece por contacto con el aire.

\subsubsection{Distribución geográfica-hábitat}

El rango de distribución natural de $P$. canaliculata comprende desde el sur de Brasil (Hayes et al., 2008) hasta el sur de la provincia de Buenos Aires, Argentina convirtiéndolo en el ampulárido más austral del mundo (Martín et al., 2001).

La reproducción es estacional y al parecer relacionada con la latitud, temperatura y precipitaciones. En áreas tropicales se comporta como una especie semélpara, es decir, se reproduce durante todo el año con un único período reproductivo en la vida; mientras que en el límite austral de su distribución, debido 
a la marcada estacionalidad térmica, se comporta como una especie iterópara con más de un período reproductivo luego de alcanzar la madurez, el cual se reduce a seis meses desde octubre a abril permaneciendo reproductivamente inactiva el resto del año (Martín et al., 2001).

Habita ambientes lóticos y lénticos, ubicándose cerca de las orillas donde existe vegetación subacuática, en especial macrófitas, que constituyen su principal fuente de alimentación (Martín et al., 2001).

Entre 1979 y 1980 fue introducida en Taiwán y posteriormente en Japón, Corea, Malasia, Indonesia y Tailandia (Mochida, 1991) principalmente para consumo humano por considerarse un alimento con alto contenido proteico y como animal ornamental de acuario (Naylor, 1996).

\subsubsection{Aspectos ecológicos}

Este caracol polífago se alimenta básicamente de macrófitas (Estebenet, 1995), aunque también puede alimentarse de detritos o materia vegetal en descomposición y realizar alimentación ciliar, un tipo de filtrado de partículas en la superficie del agua haciendo circular la misma con movimientos ciliares del pie que adopta forma de embudo (Cazzaniga \& Estebenet, 1984). Se alimenta de forma bastante continua durante el día y la noche aunque los niveles de actividad general son mayores durante las horas de oscuridad (Estebenet \& Martín, 2002).

Su ciclo de vida en nuestro país es largo (más de 3 años) y muy plástico ajustándose a diferentes condiciones ambientales, pudiendo llegar a completarlo en condiciones de laboratorio con sólo el 20 \% de una ración completa de alimento (Estebenet \& Cazzaniga, 1993, Estebenet \& Martín, 2002, Tamburi \& Martín, 2009a).

Son escasos los enemigos naturales con los que cuenta y los mismos no son importantes en su regulación poblacional (Cowie, 2002); los depredadores de los caracoles adultos más conocidos en nuestro país son el "gavilán caracolero" (Rostrhamus sociabilis Vieillot, 1817) que presenta un pico ganchudo adaptado para 
la extracción de gasterópodos de su concha y el "carao" (Aramus guarauna Linnaeus, 1766); varias especies de peces, ratas y anfibios han sido registrados alimentándose de caracoles (Carlsson et al., 2004b, Cowie, 2002, Yusa et al., 2000, Yusa et al., 2006) mientras que es importante resaltar que, llamativamente, existe escasa información sobre los depredadores de sus huevos; fueron reportados la "hormiga de fuego" (Solenopsis geminata) en Asia (Yusa, 2001) y recientemente hay registro de observaciones de laboratorio sobre la predación de Quantula striata (Pulmonata, Stylommatophora) (Ng \& Tan, 2011).

\subsubsection{Importancia económico-sanitaria}

Pomacea canaliculata puede actuar como hospedador intermediario del nematode Angiostrongylus cantonensis. Si un animal portador es ingerido por humanos puede transmitírselos, causando meningoencefalitis eosinofílica, con daños cerebrales permanentes o la muerte. Se informaron numerosos casos de infección en Taiwán, Japón y China (Lv et al., 2009, Mochida, 1991). A. cantonensis es de origen asiático, pero ya se encuentra en un foco de esta infestación en Centroamérica (Slom \& Johnson, 2003; Slom et al., 2002).

Dentro de los aspectos positivos de la especie para el hombre, y dada su voracidad, se lo ha propuesto como potencial controlador de las malezas acuáticas que invaden los canales de drenaje como los del Río Colorado (Cazzaniga, 1981).

La especie fue introducida en 1983 en el sudeste asiático sin mayores controles principalmente para el consumo humano y acuarismo. Con el transcurso del tiempo fue estableciéndose en campos abiertos debido al fracaso de los emprendimientos que hizo que muchas granjas fueran abandonadas $y$, con la ayuda de acuaristas y acuicultores, los caracoles fueron ampliamente dispersados, convirtiéndose en plaga de arrozales y otros tipos de cultivo. Es considerado uno de los 100 peores invasores a nivel mundial y es el único caracol de agua dulce de esta lista (Lowe et al., 2004). 
En estas regiones tropicales de Asia sudoriental, al no existir estacionalidad térmica, la especie se reproduce todo el año con un ciclo biológico corto; estos motivos junto con su voracidad por la vegetación acuática probablemente permitió a esta especie colonizar rápidamente nuevos ambientes.

Además de los graves problemas agrícolas en los arrozales con pérdidas económicas millonarias en Vietnam, Filipinas, Taiwan, China y Tailandia, estos invasores afectan la integridad de los ecosistemas naturales, produciendo fuertes cambios en el flujo de nutrientes y ocasionando pérdida de plantas acuáticas (Carlsson et al., 2004a). Por su actividad predatoria y colonizadora, impacta en poblaciones autóctonas siendo capaz de desplazarlas, como ocurrió con $P$. diffusa en Estados Unidos (Rawlings et al., 2007) y también a través de la competencia puede controlar poblaciones de Biomphalaria glabrata, hospedador intermediario del Schistosoma mansoni causante de la esquistosomiasis humana (Milward-DeAndrade et al., 1978, Pointier \& Jourdane, 2000). Además se ha reportado que $P$. canaliculata preda a Biomphalaria peregrina (Cazzaniga, 1990).

También ha sido introducido en Estados Unidos, Hawai, Papúa Nueva Guinea y República Dominicana (Hayes et al., 2008, Rawlings et al., 2007), donde se ha establecido como plaga del taro sin efecto económico notable, pero provocando cambios en el ecosistema natural.

Su éxito como invasor se atribuye a la gran plasticidad fenotípica en los rasgos de la historia de la vida (Tamburi \& Martín, 2009b).

Hasta el momento, los métodos de control llevados a cabo tienen escasos resultados. El control químico por el uso de molusquicidas a gran escala no es recomendable por su alto costo, impacto para el ambiente y salud humana, además de lograr solo una erradicación temporaria. El control biológico con depredadores, parásitos y agentes patógenos apenas ha sido abordado y es muy controvertido.

A pesar de la diversidad de enfoques de control y de gestión que se han desarrollado, esta problemática aún no se ha resuelto, en parte porque se desconocen muchos aspectos sobre la biología reproductiva de este caracol para establecer estrategias de control exitosas (Cowie, 2002). 


\subsection{Biología reproductiva}

1.2.1 Estrategias reproductivas y de oviposición

Las hembras de $P$. canaliculata oviponen repetidas veces luego de una única cópula (Estebenet \& Cazzaniga, 1993), son capaces de almacenar esperma activo por más de 140 días (Estebenet \& Martín, 2002), existe paternidad múltiple (Yusa, 2004) y ofrenda nupcial (Burela \& Martín, 2007).

La actividad de oviposición ocurre principalmente de noche o en horas tempranas de la mañana (Albrecht et al., 1996); depositando huevos coloreados fuera del agua, cementados con una cáscara calcárea sobre la vegetación, rocas u otros objetos emergentes cercanos a las márgenes del cuerpo de agua (Albrecht et al., 1996, Estebenet \& Cazzaniga, 1993, Estebenet \& Martín, 2002,) (fig. 1.1).

Esta estrategia de oviposición protegería a los embriones de sus depredadores acuáticos y posiblemente de la baja tensión de oxígeno del agua, pero al mismo tiempo los somete a condiciones ambientales agresivas como radiación ultravioleta, stress térmico, desecación y potenciales depredadores terrestres (Przeslawski, 2005, Przeslawski et al., 2004). La viabilidad de los embriones frente a las condiciones extremas en las que transcurre su desarrollo sugieren la existencia de adaptaciones fisiológicas y bioquímicas, que están siendo estudiadas en nuestro laboratorio y se describen más adelante.

Figura 1.1: Puestas de huevos de Pomacea canaliculata
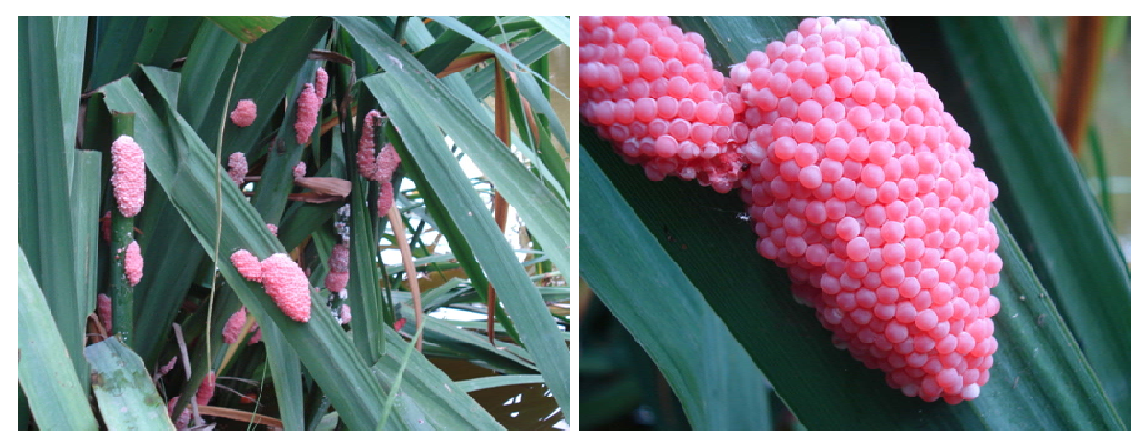
Cada puesta tiene un número muy variable de huevos pudiendo desovar en promedio unos 4500 huevos durante toda su vida (Estebenet \& Martín, 2002, Martín \& Estebenet, 2002). Las puestas están conformadas por cientos de huevos dispuestos de manera compacta, con una cubierta de carbonato de calcio y una coloración rosa muy llamativa que parece ser una advertencia para posibles depredadores, la cual indicaría que los huevos poseen algún tipo de defensa, si bien al comienzo de este trabajo no existía ninguna información de cuál era la naturaleza de estas defensas.

Escapar de la depredación es esencial para la supervivencia de la mayoría de los animales y ha resultado en la evolución de una amplia diversidad de tácticas de evasión. Dentro de estas tácticas, muchas veces los organismos emplean una coloración conspicua (aposemática) para anunciar la presencia de defensas y disuadir a los depredadores que cazan visualmente, tal como se observa en muchos invertebrados, peces, anfibios, serpientes y aves (Ruxton et al., 2004).

La coloración aposemática advierte la presencia, no excluyente, de dos tipos de "castigo" al depredador: sustancias no palatables o compuestos peligrosos. Ambos tipos de defensas parecen estar presentes en Pomacea. En este sentido los huevos de P. paludosa parecen ser no palatables, por lo menos para algunos vertebrados en condiciones experimentales (Snyder \& Snyder, 1971, Kushlan, 1978), mientras que en nuestro laboratorio se identificó parte de las defensas de los huevos de P. canaliculata (Dreon et al., 2010) como se describe a continuación. En el presente trabajo se agregan otras novedosas defensas.

Los escasos registros de depredadores de los huevos y, el comportamiento de los depredadores de adultos (el gavilán caracolero y el carao) que descartan la glándula del albumen de las hembras de conspicua coloración rosada (obs. personal) apoyarían la hipótesis de que la coloración de los huevos es de tipo aposemático, aunque la base experimental de esa función no cuenta aún con evidencias concluyentes. 
1.2.2 Fluido perivitelino. Componentes y funciones

EI FPV es sintetizado por la glándula del albumen. Está compuesto por complejos glico-lipoproteicos denominados perivitelinas (PV) y una gran cantidad de hidratos de carbono, especialmente el polisacárido galactógeno (Garín et al., 1996). EI FPV representa no solo la principal fuente de energía y aporte estructural para los embriones, sino que a través de sus perivitelinas brinda diversas funciones de protección.

La eficiencia de conversión energética calculada para los distintos componentes del FPV indican que los glúcidos y en mucho menor grado las proteínas son incorporados y utilizados por el embrión, principalmente como fuente energética; mientras que existe una incorporación y síntesis neta de proteínas y lípidos a lo largo del desarrollo, especialmente en las etapas de organogénesis (Heras et al., 1998).

Además de proveer reservas, la elevada glicosilación de las perivitelinas y el gran contenido de galactógeno presente son probablemente los responsables de mantener un ambiente apropiado evitando la deshidratación de los huevos (Heras et al., 1998).

EI FPV también provee de pigmentos carotenoides cuyo rol sería no sólo la defensa (otorgando la posible coloración aposemática) sino también como fotoprotector y luego como antioxidante.

En síntesis, la presencia en el FPV de moléculas que evitan la desecación, antioxidantes y fotoprotectoras del embrión (Dreon et al., 2004b, 2006), sumado a las posibles defensas mediante coloración de advertencia y sustancias antinutritivas y antidigestivas (Dreon et al., 2010, Heras et al., 2007) conforman una eficiente y compleja estrategia reproductiva que evita la depredación y permite a los embriones desarrollarse bajo condiciones hostiles. En esta estrategia las perivitelinas juegan un rol central y se describen en detalle a continuación. 


\subsubsection{Perivitelinas de Pomacea canaliculata}

Las perivitelinas presentes en el FPV de P. canaliculata son PV1 u ovorrubina (OR) descripta por Cheesman (1958), PV2 y PV3 aisladas y caracterizadas bioquímicamente por Garín et al (1996). Fueron consideradas únicamente como moléculas de reserva para el embrión, pero en los últimos años, en nuestro laboratorio se ha descubierto que desempeñan funciones adicionales durante la embriogénesis (para revisión ver Heras et al., 2007).

Durante el desarrollo embrionario, son endocitadas y consumidas selectivamente por el embrión y en la captación, probablemente intervengan los diferentes patrones de glicosilación (Dreon et al., 2004a, Heras et al., 1998). PV2 y PV3 se consumen totalmente antes de la eclosión, quedando únicamente $O R$ en el FPV. Luego de la eclosión, la OR sigue presente en el tracto digestivo de los caracoles recién nacidos durante los primeros días de vida libre (Heras et al., 1998).

Ovorrubina: es la perivitelina más estudiada de los moluscos; es un complejo lipoglico-carotenoprotéico de $300 \mathrm{kDa}$ de peso molecular, con una densidad de hidratación que corresponde a una lipoproteína de muy alta densidad (VHDL). Es la principal proteína del FPV y representa el $57 \%$ de la proteína total. Se sintetiza en las células albúmino-secretoras de la zona parenquimal de la glándula del albumen (Catalán et al., 2006, Dreon et al., 2003). La secuencia N-terminal no mostró homología con ninguna otra conocida, mientras que mediante espectrometría de masas, se identificó entre sus fragmentos trípticos uno con homología con un inhibidor de serin-proteasas de la familia Kunitz (Dreon et al., 2010).

Presenta un 0,33\% de lípidos, principalmente esteroles libres y fosfolípidos (Garín et al., 1996). Es una glicoproteína altamente glicosilada (17,8 \% p/p). Sus oligosacáridos tienen alta proporción de manosa y $\mathrm{N}$-acetil glucosamina (GIcNAc), y 
están unidos al esqueleto proteico mediante enlaces de tipo $\mathrm{N}$ - y O-glicosídicos (Dreon et al., 2004a).

Presenta elevada estabilidad frente a la temperatura, manteniendo su estructura inalterada aun a $95^{\circ} \mathrm{C}$ y también frente a un amplio rango de valores de pH (Dreon et al., 2007, Dreon et al., 2008).

El componente carotenoide de la OR está constituido mayoritariamente por astaxantina. La apo-ovorrubina ejerce un efecto estabilizador sobre este pigmento, aumentando su vida media en el fluido perivitelino, esto es de gran utilidad por su capacidad antioxidante y cumple un rol de fotoprotección al embrión en desarrollo (Dreon et al., 2004b) al igual que otorgar la probable coloración de alarma al huevo (Dreon et al., 2004b, Heras et al., 2007).

Norden (1972) describió que la OR tiene actividad de inhibidora de proteasas, a las que interpretó como un posible sistema de defensa antimicrobiana. Sin embargo, estudios recientes demuestran que esta actividad estaría relacionada con una función antinutritiva y antidigestiva (Dreon et al., 2010) impidiendo al depredador digerir e incorporar los nutrientes de los tejidos consumidos. Su modo de acción es similar al de los inhibidores de proteasas vegetales contra depredadores herbívoros ampliamente estudiados (Wingate et al., 1989, Alves García et al., 2004, Zavala \& Baldwin, 2004, Chye et al., 2006) y representaría la primera mención de este tipo de defensas en el reino animal.

PV3: corresponde a una HDL (lipoproteína de alta densidad) que representa el $35,5 \%$ de las proteínas del perivitelo. A diferencia de las otras perivitelinas de $P$. canaliculata, solo se conoce su composición bioquímica (Garín et al., 1996).

La fracción PV3 fue separada en dos subfracciones por cromatografía:

1) Fracción heterogénea " $h$ " con un $5 \%$ de lípidos, mayormente esteroles libres, fosfolípidos y ácidos grasos libres, presenta dos partículas principales de 100 y 64 kDa por electroforesis en condiciones nativas.

2) Fracción pigmentada "p", que tiene 9,5\% de lípidos (30\% del total de los lípidos del FPV) y coloración amarilla por la presencia de un pigmento, probablemente 
carotenoide que junto con $O R$ dan la coloración al huevo. También presenta cantidades importantes de hidrocarburos, esteroles esterificados, ácidos grasos libres y triacilgliceroles. Es la mas pequeña de las perivitelinas, con un peso molecular nativo de $26 \mathrm{kDa}$.

PV2: es la perivitelina menos representada en el FPV, con un $7,3 \%$ en peso de las proteínas totales presentes en un huevo recién puesto. Es una lipoproteína con densidad de hidratación correspondiente a las VHDL y peso molecular de 400 kDa. Está formada por dos subunidades de 67 y $31 \mathrm{kDa}$ que se encuentran en una relación en masa aparente de 7:3 (Garín et al., 1996).

Al igual que $O R$, es sintetizada en las células albúmino-secretoras de la zona parenquimal de la glándula del albumen (Catalán et al., 2006). Las secuencias Nterminal de sus subunidades no mostraron homología con ninguna secuencia conocida (Dreon et al., 2002).

Presenta un 3,75\% de lípidos, la mayoría estructurales como fosfolípidos y esteroles libres, aunque también presenta importantes cantidades de lípidos energéticos como triacilglicéridos y ácidos grasos libres (Garín et al., 1996). Se encuentra levemente glicosilada, con un $2,5 \% \mathrm{p} / \mathrm{p}$ y una composición de carbohidratos similar a la de la $O R$, aunque con algunas diferencias en cuanto al tipo de oligosacáridos (Dreon et al., 2004a).

Hasta el comienzo de este trabajo, la única función descripta para esta perivitelina era la de proveer de nutrientes al embrión durante su desarrollo (Heras et al., 1998). En la presente tesis se profundiza el estudio de su estructura, estabilidad y posibles funciones en el huevo de Pomacea canaliculata.

\subsection{Toxinas de moluscos}

Los moluscos marinos son el grupo de invertebrados acuáticos con mayor número de toxinas (West et al., 1996). Los animales que poseen compuestos tóxicos 
se suelen dividir en dos grupos: (a) venenosos, si están equipados con un aparato específico para la síntesis y entrega de su veneno (caracoles cónidos) y (b) ponzoñosos si carecen de aparato específico pero tienen compuestos tóxicos en sus tejidos (Brodie, 2002, West et al., 1996,). P. canaliculata puede ser incluido en este último grupo.

Algunos moluscos presentan defensas físicas como una conchilla que los protege o defensas químicas; toxinas biosintetizadas por ellos mismos 0 incorporadas a través del alimento.

Sólo se conocen especies venenosas marinas; en los caracoles Conidae la glándula de veneno es una glándula salival modificada con un conducto que lleva una rádula toxoglosa, formada por una sola hilera de dientes huecos con los que atacan, paralizan o matan animales. Algunos utilizan el veneno como un mecanismo defensivo (Brodie, 2002).

\section{Bivalvos:}

Los bivalvos marinos pueden ser vectores de biotoxinas involucradas en la intoxicación humana por consumo de mariscos "contaminados". Los bivalvos se alimentan de fitoplancton que, cuando es tóxico, se filtra como alimento por bivalvos comestibles tales como almejas, mejillones, ostras o vieiras, y las toxinas se acumulan en sus tejidos, alcanzando niveles que pueden ser letales para los seres humanos u otros consumidores (Ciminiello \& Fattoruso, 2006).

\section{Cefalópodos:}

Existen pulpos venenosos, entre otros Hapalochlaena maculosa de Australia, cuya saliva presenta tetrodotoxina (TTX), neurotoxina que paraliza la presa y puede causar entumecimiento, parálisis y muerte en humanos; al igual que los bivalvos, probablemente la obtienen de la alimentación de microorganismos tóxicos (Brodie, 2002). 


\section{Gasterópodos:}

Muchos opistobranquios secuestran toxinas de sus alimentos, por ejemplo, algas, esponjas, celenterados, briozoos y tunicados; las incorporan en sus tejidos y huevos y las emplean como un mecanismo de defensa química que ayuda a disuadir a los depredadores o para cazar, paralizando a sus presas. Muchos poseen coloración aposemática (Avila, 2006).

De manera semejante, un gran número de caracoles marinos (Caenogastropoda) contienen en sus tejidos TTX, un bloqueante de canales de sodio. Estos caracoles adquieren la toxima cuando se alimentan de microorganismos patógenos. Las toxinas se acumulan en la glándula digestiva y pueden causar intoxicaciones cuando son ingeridos por su depredador (West et al., 1996).

Dentro de los Caenogastropoda, los caracoles más venenosos son los cónidos que se encuentran en mares tropicales y templados. Existen más de 500 especies conocidas y todas poseen un órgano venenoso que consiste en una rádula altamente especializada, con dientes huecos que inyectan el veneno cuyo efecto produce parálisis y muerte a mamíferos y peces (Brodie, 2002, West et al., 1996). Las toxinas de estos venenos se llaman conotoxinas $y$, a diferencia de los casos anteriores, son de naturaleza proteica y sintetizadas por el propio organismo. Estas toxinas son pequeños péptidos ricos en cisteínas y que poseen una enorme diversidad estructural y funcional. Están recibiendo una atención creciente por su acción muy específica sobre canales o receptores nerviosos claves de la excitabilidad de membranas y sinapsis químicas (Alonso et al., 2003). La mayoría de las familias de conotoxinas tiene como blanco un canal iónico específico, por ejemplo las denominadas $\omega$-conotoxinas para los canales de calcio, las aconotoxinas para los receptores nicotínicos, etc. (Terlau \& Olivera, 2004). Otros venenos encontrados en el género Conus son las tesulatoxinas y conantokinas (péptidos sin enlaces disulfuro), y las conopresinas (péptidos con acción semejante a la de la vasopresina/oxitocina)(West et al., 1996).

Muchas neurotoxinas o sus derivados se utilizan como agentes terapéuticos (Adams \& Olivera, 1994). Un ejemplo es la $\omega$-conotoxina que sintetiza Conus magus 
que afecta selectivamente los canales de calcio tipo $\mathrm{N}$ presinápticos (Favreau et al., 1999) bloqueando de esta forma la unión neuromuscular (Alonso et al., 2003). El analgésico comercial "Prialt" se sintetiza a partir de esta conotoxina cuya droga es el ziconotido (lab. Elan de Irlanda, aprobado en los EEUU y Europa), que al evitar la apertura y flujo de iones calcio dificulta la transmisión de estímulos e impide que el dolor se haga consciente (Bowersox \& Luther, 1998, Wermeling, 2005).

Otros Caenogastropoda marinos y carnívoros también tienen toxinas en su glándula salival. Los mejor estudiados son los de las familias Buccinidae y Cymatiidae. En particular los representantes del género Neptunea (fam. Buccinidae) contienen altas concentraciones de la toxina "tetramina" (tetrametilamonio) (Kawashima et al., 2002, Shiomi et al., 1994) cuya ingestión puede llevar a la intoxicación en humanos. Por otra parte, también han sido purificadas las ecotoxinas del caracol Monoplex echo (fam. Cymatiidae), todas formadas por un solo polipéptido de unos $25 \mathrm{kDa}$ (Shiomi et al., 2002). Esta toxina causa hemólisis severa, produciendo eventualmente la muerte en humanos (Shiomi et al., 1994).

Además de las mencionadas, hay muchos otros caracoles tóxicos, pero existe muy poca información sobre la identidad y modo de acción de sus toxinas. Se supone que los gasterópodos son una rica fuente de compuestos neuroactivos, muchos de los cuales son nuevos para la ciencia tanto por su acción fisiológica como por sus propiedades químicas. Hasta el presente estudio, no existía en la literatura ninguna mención sobre la presencia de toxinas en caracoles de agua dulce. 


\section{CAPITULO 2}

Objetivos 


\section{CAPITULO 2: Objetivos}

A pesar de que la llamativa coloración y la falta de depredadores de los huevos de $P$. canaliculata ya es mencionada por d'Orbigny (1846), parece ser de vital importancia en la supervivencia del embrión y las estrategias reproductivas. Hasta el comienzo de nuestro trabajo de tesis, la presencia de defensas sólo se asumía, pero no existía ninguna información sobre cuál sería su naturaleza.

Nuestro grupo de trabajo ha estado estudiando las estrategias reproductivas de esta especie, comenzando con la descripción bioquímica del fluido perivitelino (Garín et al., 1996, Heras et al., 1998) y más recientemente se ha enfocado en estudiar la bioquímica, biofísica y funciones de la OR (Dreon et al., 2002, 2003, 2004, 2006, 2007, 2008, 2010), prácticamente la única caracterización de una perivitelina en gasterópodos. Estos estudios aportaron la primera información detallada del fluido perivitelino y sus perivitelinas, sobre la que se apoya el presente trabajo.

El objetivo general de esta tesis es profundizar el conocimiento acerca de la biología reproductiva de este gasterópodo de gran importancia ecológica, económica y sanitaria. Se empleará como modelo la PV2 con el fin de interpretar, a partir de sus relaciones estructura-función, su significado fisiológico en el contexto de las adaptaciones que harían que esta especie posea huevos virtualmente carentes de depredadores naturales.

En particular se pretende:

Aspectos estructurales: (Capítulos 4 y 5)

- Estudiar la estructura y conformación de la PV2. 
* Evaluar la estabilidad estructural de la PV2 frente a las alteraciones provocadas por la temperatura, el pH y agentes químicos, así como su resistencia a la acción de proteasas.

\section{Aspectos funcionales: (Capítulos 6 y 7 )}

* Estudiar la toxicidad de los componentes de la fracción soluble de huevos sobre ratones.

* Evaluar la toxicidad de PV2 en un anfibio (Lithobates catesbeianus) y un mamífero (Mus musculus).

* Investigar el efecto de la toxina sobre diferentes órganos y su posible mecanismo de acción.

* Analizar la relación entre la estabilidad de PV2 frente a proteasas digestivas, su estabilidad frente al pH y su capacidad inmunogénica; discutir las implicancias funcionales en su efecto tóxico y el aporte nutricio sobre un potencial depredador.

* Determinar en condiciones controladas de laboratorio, si el esfuerzo reproductivo y la alimentación alteran los niveles de defensas bioquímicas y/o la posible coloración de advertencia del huevo. 


\section{CAPITULO 3}

Metodologia 


\section{CAPÍTULO 3: Metodología}

\subsection{Aislamiento de las perivitelinas de P. canaliculata}

\subsubsection{Recolección de las muestras}

Los huevos de Pomacea canaliculata fueron recolectados en márgenes de cuerpos de agua en La Plata (lago del Bosque y lago del Parque Saavedra), provincia de Buenos Aires durante la estación reproductiva (octubre - abril).

Todas las puestas se analizaron en un estado embrionario inferior al de mórula que fue evaluado mediante microscopía (Heras et al., 1998). Especímenes voucher recogidos en el mismo lugar fueron depositados en la colección del Museo de La Plata (MLP 12936).

\subsubsection{Obtención de la fracción soluble de los huevos}

Las puestas de huevos se homogeneizaron en un homogeneizador Potter (Thomas Sci., Swedesvoro, NJ) en buffer Tris- $\mathrm{HCl}$ 0,02 M pH 6,8 con 0,8 mM de aprotinina (Trasylol, Mobay Chemical Co., Nueva York). La relación buffer:muestra utilizada fue $3: 1 \mathrm{v} / \mathrm{v}$.

El homogenato fue centrifugado secuencialmente a 10,000 xg por $30 \mathrm{~min} y$ luego a 100,000 xg por $50 \mathrm{~min}$; el pellet fue descartado y el sobrenadante se empleó para diversos experimentos (fracción soluble de huevo).

\subsubsection{Aislamiento y purificación de perivitelinas}

Un volumen de $1,4 \mathrm{ml}$ de la fracción soluble de huevo fue sometido a ultracentrifugación en bromuro de sodio $(\mathrm{NaBr}) \quad \delta=1,26 \mathrm{~g} / \mathrm{ml}$. La ultracentrifugación se realizó a 207,000 xg y $10{ }^{\circ} \mathrm{C}$ durante $22 \mathrm{~h}$ en una ultracentrífuga Beckman L8M (Beckman, Palo Alto, CA) con un rotor SW60 Ti. Se recolectó la fracción enriquecida en PV2, que corresponde a la única fracción 
incolora (fig. 3.1), que se concentró y desaló mediante centrifugación con Centricon (Amicon, USA) con membrana de corte de 50,000 MW.

Figura 3.1: Resultados obtenidos luego de la ultracentrifugación de fracción soluble de huevo

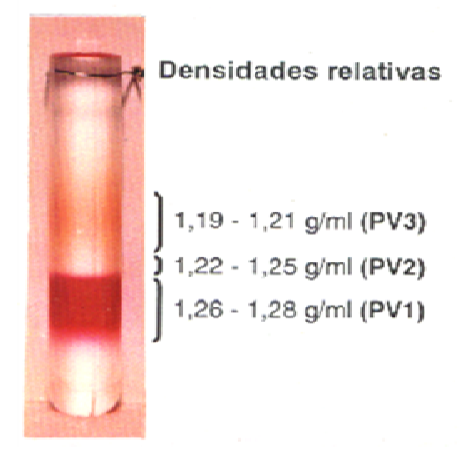

La PV2 fue purificada posteriormente por cromatografía líquida de alta presión (HPLC) usando un equipo Merk-Hitachi (Hitachi Ltd., Tokyo, Japan) con una bomba L-6200 y un detector UV L-4200, a una longitud de onda de $280 \mathrm{~nm}$. Se utilizó una columna de intercambio iónico Mono Q 10/100 GL Tricorn (Amersham Biosciences, Uppsala, Suecia) con un gradiente 0-1 $\mathrm{M}$ de $\mathrm{NaCl}$ en buffer Tris- $\mathrm{HCl}$ $20 \mathrm{mM}$ a un $\mathrm{pH}$ de 8,5 .

El pico correspondiente a PV2 fue finalmente purificado por cromatografía de exclusión molecular (200 HR Superdex 10/20, Amersham-Pharmacia, Uppsala, Suecia) con un gradiente isocrático de buffer fosfato de sodio $50 \mathrm{mM}, 150 \mathrm{mM}$ $\mathrm{NaCl}, \mathrm{pH} 7,6$ y su pureza fue evaluada mediante geles de poliacrilamida mediante electroforesis en condiciones nativas (ver sección 3.3; fig. 3.2.B).

Purificación de fracciones proteicas para ensayos de toxicidad:

Se utilizó la fracción soluble de huevo, parte de la cual fue fraccionada por cromatografía de intercambio iónico en las mismas condiciones que las descriptas previamente; así se obtuvieron las tres fracciones proteicas mayoritarias (fig. 3.2.A) denominadas perivitelinas PV1 (OR), PV2 y PV3 (Garín et al., 1996). Cada fracción proteica fue utilizada en ensayos con ratones para evaluar su toxicidad (ver más adelante). 
Figura 3.2: Purificación de perivitelinas. (A) Cromatograma de fracción soluble de huevo por cromatografía de intercambio iónico. (B) Fracción de PV2 del panel A purificada por cromatografía de exclusión molecular y pureza verificada por electroforesis PAGE nativa (en recuadro)
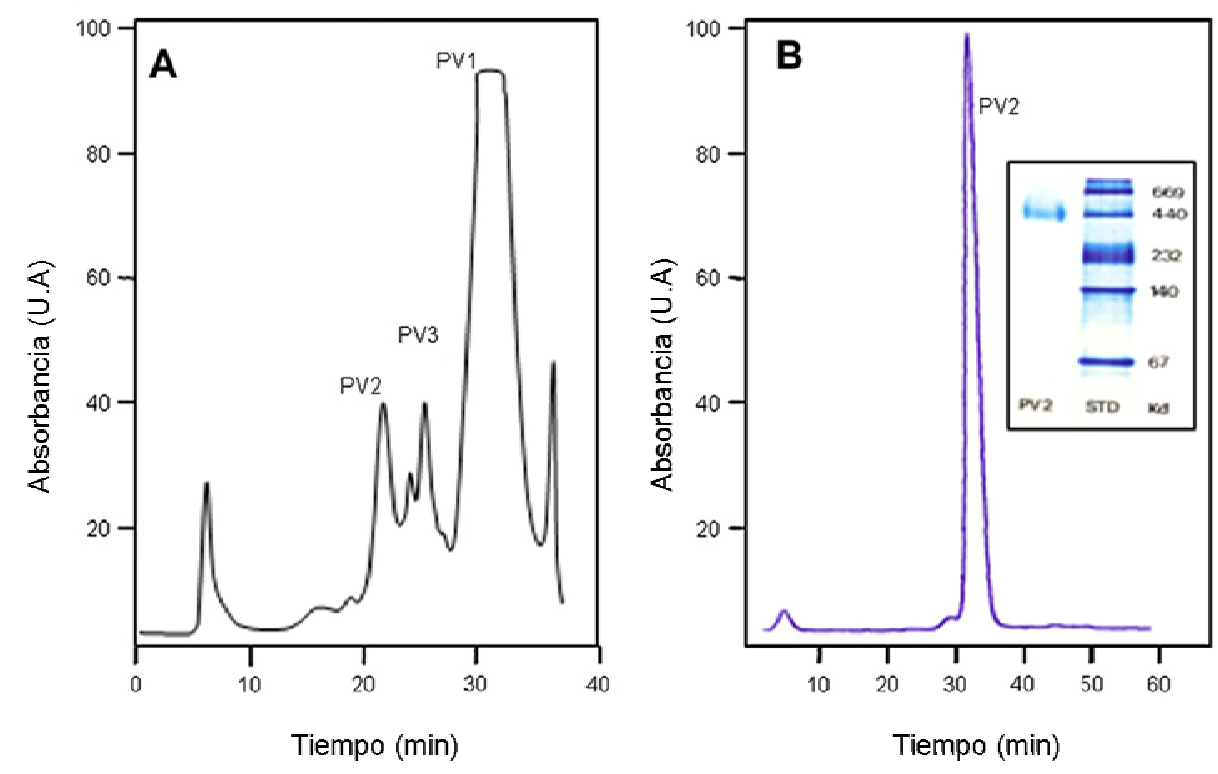

\subsection{Cuantificación de proteínas totales}

Se midió el contenido de proteína total mediante el método de Lowry et al. (1951). El primer paso de esta reacción colorimétrica implica la formación de un complejo cobre-proteína en un medio alcalino. Este complejo reduce posteriormente al reactivo de Folin-Ciocalteu (Acido fosfomolíbdicofosfowolfrámico) produciendo una coloración azul intensa, proporcional a la cantidad de enlaces peptídicos presentes en el tubo. En cada determinación se construyó una curva de calibración utilizando albúmina sérica bovina (BSA) como patrón. La intensidad de color se cuantificó a 750 nm en un espectrofotómetro.

\subsection{Electroforesis en geles de poliacrilamida}

Las proteínas son moléculas que poseen carga que refleja su composición en aminoácidos cargados. En las técnicas electroforéticas, las proteínas se introducen 
en un campo eléctrico, en el que migrarán a una velocidad que depende de su carga neta, tamaño, forma y viscosidad del medio en el cual se mueve.

Con el fin de controlar la pureza y pesos moleculares de las perivitelinas, se realizaron dos tipos de electroforesis: en condiciones nativas y disociantes. En ambos casos se utilizaron marcadores de alto y bajo peso molecular comerciales (GE Healthcare Bioscience, Uppsala, Suecia).

- Electroforesis en geles en gradiente de poliacrilamida en condiciones nativas (PAGGE)

En este sistema las proteínas migran dependiendo de su relación carga/masa hasta que el tamaño del poro impide su migración. El soporte utilizado fue una matriz polimerizada de acrilamida, N,N-metilen-bis acrilamida, como catalizador tetrametilendiamina (TEMED) y como iniciador persulfato de amonio (ver figura). Este soporte combina la separación mediante el efecto tamiz molecular y la movilidad eléctrica.

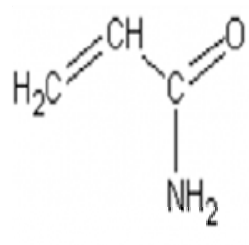

Acrilamida

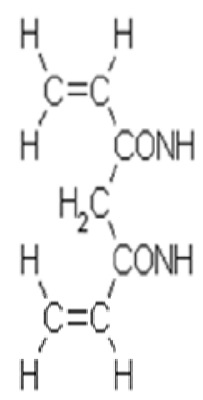

N,N'-Metilenbisacrilamida

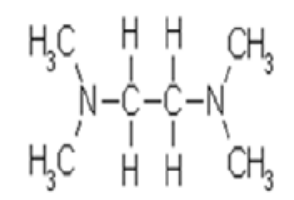

$N, N, N^{\prime}, N^{\prime}$ tetrametiletilendiamina

(TEMED)

(TEMED)
$\left(\mathrm{NH}_{4}\right)_{2} \mathrm{~S}_{2} \mathrm{O}_{8}$

APS

Se utilizó un sistema vertical discontinuo que consiste en dos geles contiguos pero de diferente diámetro de poro, pH y fuerza iónica; un gel separador por debajo sobre el que se polimeriza un gel concentrador.

El gel concentrador fue preparado con acrilamida al $4 \%(p / v)$ y el gel separador se preparó formando un gradiente lineal entre $4 \%$ y $20 \%(p / v)$ de acrilamida mediante un sistema de vasos comunicantes. 
Se utilizaron geles de 0,75 mm de espesor y una cuba electroforética Mini Protean III (Bio Rad), con una fuente de poder Power 200-2.0 Power Supply (Bio Rad). Las electroforesis se realizaron a un voltaje constante de $120 \mathrm{~V}$ durante $4 \mathrm{~h}$.

- Electroforesis en condiciones desnaturalizantes: SDS-PAGGE

El método utilizado fue el de Laemmli (1970), en condiciones similares a la PAGGE pero con el agregado de 0,1\% de dodecil sulfato sódico (SDS) a los geles y buffers. Este detergente se une a las cadenas polipeptídicas desnaturalizadas y apantalla la carga propia de la proteína, confiriéndole al complejo una carga neta negativa proporcional a su masa, de manera que todas las proteínas complejadas con SDS migren hacia el ánodo a una velocidad inversamente proporcional a su masa.

Se puede así determinar el peso molecular aparente de la proteína comparándola con un patrón de proteínas de pesos moleculares conocidos colocado en el mismo gel.

Las muestras a analizar se disolvieron en buffer muestra que contenía 33,2 $\mu l$ del buffer del gel de resolución 3 M; 0,2 mg de azul de bromo fenol (colorante); $1,25 \mathrm{ml}$ de SDS (20\%); $1 \mathrm{ml}$ de glicerina.

En los experimentos para evidenciar la presencia de puentes disulfuro inter o intracatenarios, los mismos fueron reducidos por el agregado al buffer de 0,5 ml de $\beta$-mercaptoetanol ( $\beta-M E)$.

Las muestras se calentaron luego a $100{ }^{\circ} \mathrm{C}$ durante 5 min con el objetivo de desnaturalizar las proteínas y reducir los puentes disulfuro (en el caso de tener agregado el agente reductor $\beta-M E)$.

Los experimentos electroforéticos se realizaron a voltaje constante (120 V), $1,5 \mathrm{~h}$.

Para las dos electroforesis previamente descriptas, las proteínas se tiñeron con tinción Coomassie Blue que contiene Coomassie Brilliant Blue G-250 (0,04\% $\mathrm{p} / \mathrm{v})$ y ácido acético (10\% p/v) disueltos en una mezcla de metanol:agua (40:60 $v / v)$. En los casos en que la masa de proteína en el gel era menor a los límites de 
detección de esta técnica $(\leq 3 \mu \mathrm{g})$, la proteína se visualizó mediante tinción con plata $\left(\mathrm{AgNO}_{3}\right)$ (Merril, 1990).

- Electroforesis bidimensional (2-DE):

Es un método que permite separar las proteínas de una mezcla según dos propiedades físicas combinadas: punto isoeléctrico (pI) y peso molecular, uno en cada dimensión.

En la primera dimensión se emplea el enfoque isoeléctrico (IEF) que permite separar las proteínas según sus pI. Se utilizaron gradientes de $\mathrm{pH}$ inmovilizados (IPGs) con una mezcla de anfolitos policatiónicos y polianiónicos en el cual las proteínas migran hasta llegar al pH que coincide con su pI; en ese momento la carga de la proteína es cero y, por lo tanto, deja de migrar en el campo eléctrico (Gorg et al., 2009).

Posteriormente, las proteínas separadas en función de sus propiedades eléctricas se separan en una segunda dimensión en función de su tamaño o peso molecular mediante electroforesis en geles de poliacrilamida (PAGE) sin gradiente de acrilamida.

Optimizando las condiciones de estas dos separaciones sucesivas se pueden analizar prácticamente todas las proteínas de un proteoma (conjunto de proteínas que se expresan en un tejido en un momento dado) en una matriz bidimensional.

En nuestros experimentos se utilizó esta metodología con el objetivo de determinar el pI de la proteína nativa así como de las subunidades que la componen.

\section{Preparación de la muestra:}

- Para analizar la proteína nativa se disolvieron $13 \mu \mathrm{g}$ de PV2 en $100 \mu \mathrm{l}$ de agua milliQ y $0,62 \mu$ de buffer IPG.

- Para analizar las subunidades primeramente se precipitó la proteína con ácido tricloroacético $10 \%(\mathrm{p} / \mathrm{v})$, DTT $20 \mathrm{mM}$ en acetona $a-20{ }^{\circ} \mathrm{C}$ durante $16 \mathrm{~h}$. Se centrifugó, descartó el sobrenadante y se lavó el pellet 2 veces con DTT 20 $m M$ en acetona. 
Luego se emplearon agentes caotrópicos, surfactantes y reductores provocando así la desnaturalización de las proteínas por ruptura de puentes de hidrógeno y disulfuro, dejando expuestos los residuos hidrofóbicos que fueron solubilizados por los agentes surfactantes. En nuestro caso el pellet de PV2 se redisolvió en $100 \mu$ de una solución de urea 7 M, tiourea 2 M, CHAPS $2 \%(v / v)$, DTT 0,56 \% (p/v), buffer IPG linear 3-10 $0.5 \%$ (v/v) (GE Healthcare, Uppsala, Suecia) y azul de bromofenol, agitado en vórtex durante $20 \mathrm{~min}$.

\section{Separación en la $1^{a}$ Dimensión (IEF):}

EI IEF se realizó con un Ettan IPGphor III (GE Healthcare) empleando tiras de $7 \mathrm{~cm}$ de largo con un gradiente lineal de pH 3-10 (GE Healthcare). La rehidratación de la tira y la aplicación de la muestra se llevaron a cabo durante 12 h a temperatura ambiente.

Después del IEF, las tiras con la muestra desnaturalizada fueron equilibradas a temperatura ambiente durante 20 min en una solución que contiene: $75 \mathrm{mM}$ Tris- $\mathrm{HCl}, 6 \mathrm{M}$ urea, $30 \%(\mathrm{v} / \mathrm{v})$ de glicerol, $2 \%(\mathrm{p} / \mathrm{v})$ de SDS, 0,002 \% (p/v) azul de bromofenol y 1 \% (p/v) DTT, y luego durante 20 min en la misma solución pero con $4,5 \%(p / v)$ de iodoacetamida en lugar de DTT.

\section{Separación en la $2^{a}$ Dimensión (PAGE o SDS-PAGE):}

Se prepararon geles de 1,5 mm de espesor para la separación en SDS-PAGE o en condiciones nativas según el caso, con 12 y $5 \%$ de acrilamida respectivamente; las tiras IPG fueron selladas en la parte superior del gel con una solución de agarosa 0,5\% y ABF 0,002 \%. Al aplicar el campo eléctrico, las proteínas migran desde el gel de IEF al otro gel donde se separan de acuerdo a su masa.

La electroforesis vertical se realizó a $15 \mathrm{~mA}$ los primeros $15 \mathrm{~min}$ y luego $2 \mathrm{~h}$ a $30 \mathrm{~mA} / g e l$. Posteriormente los geles fueron teñidos con Coomassie Brilliant Blue G-250 $2 \%$ (p/v) en $\mathrm{H}_{2} \mathrm{O}$ (Coomassie coloidal).

La estimación del pI de las proteínas se realizó determinando su posición en el gel. 


\subsection{Detección (Western blot y dot blot) y cuantificación (ELISA) de las} perivitelinas

3.4.1 Anticuerpos utilizados: Las diluciones utilizadas en cada experimento se describen en los resultados de la sección correspondiente.

Anticuerpos primarios:

- Suero de conejo: Se emplearon anticuerpos policlonales anti-PV1 y anti-PV2 producidos previamente en nuestro laboratorio (Dreon et al., 2002).

- Suero de ratas: Se sensibilizaron tres ratas de la cepa Wistar administrando por vía oral $200 \mu$ de citosol $(6,4 \mathrm{~g} / \mathrm{l})$, dos veces por día cada $12 \mathrm{~h}$ durante una semana. Paralelamente tres animales control fueron inoculados con buffer PBS. Transcurrido dicho tiempo las ratas se sangraron y sacrificaron por decapitación. La sangre recolectada fue mantenida a $37{ }^{\circ} \mathrm{C}$ por $1 \mathrm{~h}$ hasta su coagulación y luego se dejó toda la noche a $4{ }^{\circ} \mathrm{C}$ para lograr una buena retracción del coágulo. Luego de una centrifugación a baja velocidad, el suero obtenido fue guardado $a-70{ }^{\circ} \mathrm{C}$ y utilizado como anticuerpo primario para evidenciar la presencia de inmunización oral.

- Suero de ratones: ver detalles de su obtención en la sección 3.7.4.

Anticuerpos secundarios:

- Anti-IgG de conejo conjugado con peroxidasa (Bio-Rad, Hercules, CA, USA).

- Anti-IgG de ratón conjugado con peroxidasa (Bio Rad, Hercules, CA, USA).

- Anti-IgG de rata conjugado con peroxidasa (Sigma, Mo, USA).

\subsubsection{Western blot}

La técnica de western blot (WB) permite identificar una proteína en una mezcla de proteínas y obtener información de su tamaño.

Las proteínas fueron separadas mediante PAGGE o SDS-PAGGE y luego electro-transferidas a una membrana de nitrocelulosa Hybond (Amersham) 
empleando un equipo Mini Trans-blot Cell (Bio Rad, Hercules, CA, USA) aplicando una corriente eléctrica al gel de $100 \mathrm{~V}$ durante $1 \mathrm{~h}$. De esta manera se transfieren las proteínas a la membrana manteniendo el mismo patrón de separación logrado en el gel.

Como buffer de transferencia se usó Tris 25 mM, glicina 192 mM, 20 \% de metanol pH 8,3 (Towbin et al., 1977).

Para poder evaluar la eficiencia de la transferencia se emplearon marcadores de peso molecular estándares Chemiblot MW markers (Chemicon International, Temecula, CA).

Luego de la transferencia, todos los sitios en la membrana que no contienen la proteína transferida deben ser bloqueados para que el anticuerpo primario no se fije de manera inespecífica dando falsos positivos. En nuestro caso el bloqueo se realizó con una solución $5 \%(\mathrm{p} / \mathrm{v})$ de leche descremada disuelta en buffer PBS $\left(\mathrm{NaCl} 8 \mathrm{~g} / \mathrm{l}, \mathrm{KCl} 0,2 \mathrm{~g} / \mathrm{l}, \mathrm{NaH}_{2} \mathrm{PO}_{4} 0,2 \mathrm{~g} / \mathrm{l}\right.$ y $\left.\mathrm{Na}_{2} \mathrm{HPO}_{4} 1,15 \mathrm{~g} / \mathrm{l}\right)$ con el agregado del detergente Tween-20 0,005\% (v/v) (PBST) durante $2 \mathrm{~h}$ con agitación suave continua.

Terminada la incubación con la solución de bloqueo, se realizaron tres lavados de 7 min cada uno con agitación. Para detectar el antígeno transferido a la membrana se agregó el primer anticuerpo en la dilución adecuada en PBST conteniendo $1 \%$ de leche descremada. Se dejó durante toda la noche a $4{ }^{\circ} \mathrm{C}$ y luego se realizaron seis lavados de 5 min cada uno con buffer PBST con agitación para eliminar el exceso de anticuerpo.

Para detectar los anticuerpos unidos se agregó un segundo anticuerpo acoplado a la enzima peroxidasa en la dilución correspondiente en PBST 1 \% leche descremada y se mantuvo durante $2 \mathrm{~h}$ a temperatura ambiente y agitación muy suave.

Concluida esta última incubación, la membrana se lavó y reveló mediante electro-quimio-luminiscencia donde la peroxidasa conjugada al anticuerpo secundario produce la oxidación de su sustrato, que en nuestro caso fue el luminol (Sigma Chemical Co.), generando en la reacción emisión de luz (ver figura). 
Filtro de

nitrocelulosa

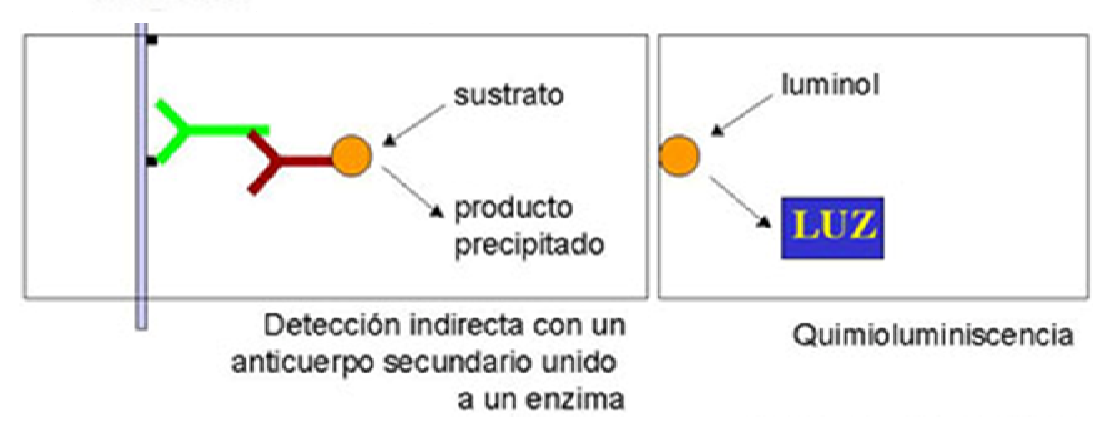

Se preparó la solución de revelado mezclando las soluciones $A$ y $B$ (ver tabla) en cuarto oscuro en una relación $1: 1(v / v)$, y se incubó con la misma la membrana durante $1 \mathrm{~min}$.

\begin{tabular}{|c|c|}
\hline Solución A & Solución B \\
\hline $50 \mu \mathrm{l}$ luminol $\left(^{\star}\right) 0,044 \mathrm{~g} / \mathrm{ml}$ en DMSO & $3 \mu \mathrm{l} \mathrm{de} \mathrm{H}_{2} \mathrm{O}_{2}$ \\
\hline $\begin{array}{l}22 \mu \text { l ácido p-cumárico(*) } 0,015 \mathrm{~g} / \mathrm{ml} \text { en } \\
\text { DMSO }\end{array}$ & \\
\hline \multicolumn{2}{|l|}{$333 \mu \mathrm{l}$ Buffer Tris- $\mathrm{HCl} 1 \mathrm{M} \mathrm{pH} 8,5$} \\
\hline $\mathrm{H}_{2} \mathrm{O}$ bidestilada cantidad suficiente hast & completar $5 \mathrm{ml}$ \\
\hline
\end{tabular}

Posteriormente se secó la membrana, se colocó en un cassette de exposición (X-Omatic cassette, Kodak) y se expuso una placa radiográfica (Hyperfilm ECL, Amersham Biosciences) entre $30 \mathrm{seg}$ y $5 \mathrm{~min}$, la cual fue luego revelada por procedimientos estándar.

\subsubsection{Dot blot}

El fundamento de esta técnica es muy similar al WB pero en este caso las muestras proteicas no se separan previamente por electroforesis, sino que se las aplica directamente en forma de una pequeña gota sobre la membrana de nitrocelulosa; por ello es una técnica más eficiente para analizar rápidamente muchas muestras purificadas utilizando pequeños volúmenes. 
Según el experimento, se aplicaron a la membrana concentraciones adecuadas de OR, PV2 o fracción soluble de huevo. Las tiras fueron bloqueadas con leche en polvo descremada $5 \%(p / v)$ disuelta en PBST durante $1 \mathrm{~h}$ a $37^{\circ} \mathrm{C}$. Los pasos siguientes son similares a los descriptos en 3.4.2, corregidos por el tipo y dilución correspondiente de anticuerpo.

La inmunorreactividad se visualizó mediante electro-quimio-luminiscencia ajustando los volúmenes de soluciones $A$ y $B$ al tamaño de la tira de nitrocelulosa.

\subsubsection{ELISA (Prueba de inmunoensayo ligado a enzimas)}

Esta técnica se utilizó con el fin de estimar la existencia de variaciones en el título de las perivitelinas mayoritarias (OR, PV2) a lo largo de sucesivas puestas de huevos obtenidas in vitro durante todo un ciclo reproductivo.

La cuantificación se basó en el ensayo descripto por Engwall y Perlmann (1972) con placas Nunc-Immunoplate Maxisorp (Nunc) y como estándar cada una de las perivitelinas purificadas. En primer lugar se realizó la puesta a punto variando las cantidades de anticuerpo primario y secundario hasta obtener la mejor respuesta.

Para realizar la curva de calibración se emplearon diluciones seriadas de la perivitelina respectiva (tabla 1.1) disuelta en un buffer $15 \mathrm{mM}$ de $\mathrm{Na}_{2} \mathrm{CO}_{3}, 35 \mathrm{mM}$ $\mathrm{NaHCO}_{3}, \mathrm{pH} 9,6$ (" buffer coating").

Las muestras de fracción soluble de huevo fueron diluidas con buffer coating y alícuotas de $50 \mu$ fueron dispensadas en cada pocillo e incubadas a $37{ }^{\circ} \mathrm{C}$ durante $90 \mathrm{~min}$. La solución de antígeno fue luego desechada y cada pocillo lavado con $300 \mu \mathrm{l}$ de PBS pH 7,4. Las placas fueron incubadas por $2 \mathrm{~h}$ a temperatura ambiente con solución de bloqueo (PBS $3 \%$ de leche en polvo descremada) $300 \mu \mathrm{l}$ por pocillo y luego lavadas 3 veces con PBST.

Se colocaron $50 \mu \mathrm{l}$ de anticuerpo primario diluido en PBST $1 \%$ de leche en polvo descremada en cada pocillo y las placas se incubaron durante toda la noche a $4{ }^{\circ} \mathrm{C}$. Posteriormente se volcó el contenido de la placa y se lavó tres veces con PBST. Por último se agregó a cada pocillo $50 \mu \mathrm{l}$ de anticuerpo secundario anti-IgG 
de conejo conjugado con peroxidasa diluido en PBST $1 \%$ de leche en polvo descremada y se incubó a $37^{\circ} \mathrm{C}$ durante $2 \mathrm{~h}$. Luego de lavar cuatro veces de la manera antes descripta, fueron agregadas a cada pocillo alícuotas de $50 \mu \mathrm{l}$ de una solución de revelado de ácido 2, 2'-azino-bis(3-etilbenzotiazol)-6-sulfónico (ABTS) y $\mathrm{H}_{2} \mathrm{O}_{2}$ (Bio-Rad Laboratories) y las placas fueron incubadas por $10 \mathrm{~min}$ a temperatura ambiente. El desarrollo de color fue detenido agregando $50 \mu$ de una solución de ácido oxálico al 2 \% (p/v). Una solución de PBS 1 \% de leche en polvo descremada fue usada como control negativo en todos los ensayos. Las muestras fueron analizadas por triplicado.

La detección del color se efectuó en un lector de placas DTX 880 Multimode detector (Beckman Coulter) a una absorbancia de $415 \mathrm{~nm}$.

Tabla 1.1: Condiciones de anticuerpos y concentraciones de perivitelinas empleadas en ELISA

\begin{tabular}{|l|l|l|l|}
\hline Perivitelina & $\begin{array}{l}\text { Curva } \\
\text { calibración }\end{array}$ & $\begin{array}{l}\text { Anticuerpo } \\
\text { primario }\end{array}$ & $\begin{array}{l}\text { Anticuerpo } \\
\text { secundario }\end{array}$ \\
\hline OR & $0-46 \mathrm{ng} / 50 \mu 1$ & $\begin{array}{l}\text { Anti-PV1 } \\
1 / 1000\end{array}$ & $\begin{array}{l}\text { Anti-IgG } \\
\text { conejo } \\
\end{array}$ \\
\hline PV2 & $0-20 \mathrm{ng} / 50 \mu 1$ & $\begin{array}{l}\text { Anti-PV2 } \\
1 / 500\end{array}$ \\
& & $1 / 5000$ & \\
\hline
\end{tabular}

\subsection{Técnicas de biología molecular}

\subsubsection{Cepas bacterianas y medios de cultivo}

Se utilizó la cepa JM 109 de la bacteria Escherichia coli. Esta cepa es sensible al antibiótico ampicilina y resulta adecuada para las aplicaciones de clonado, facilitando la estabilidad y calidad de los plásmidos obtenidos.

Se utilizó el medio de cultivo de Luria Bertani (LB) cuya composición es 10 $\mathrm{g} / \mathrm{l}$ triptona (Britania), $5 \mathrm{~g} / \mathrm{l}$ de extracto de levadura (Britania), y $5 \mathrm{~g} / \mathrm{l}$ de $\mathrm{NaCl}$ (Carlo Erba). Como medio sólido se utilizó LB adicionado con 1,5\% de agar. Tanto LB como LB-agar se esterilizaron en autoclave. 


\subsubsection{Extracción de ARN}

Este ácido nucleico es muy inestable y susceptible a la digestión mediada por nucleasas-ARNasas. Las manipulaciones y soluciones han de estar libres de ellas, para lo cual se esteriliza el material y reactivos en autoclave durante 20 min a 1 atmósfera. Además, se requiere el tratamiento previo con agua con dietilpirocarbonato $(D E P C)$ que es un agente alquilante altamente reactivo que destruye la actividad de las ARNasas.

El tejido utilizado fue la glándula del albumen del caracol Pomacea canaliculata en época reproductiva. Se extrajeron en condiciones libres de ARNasas y fueron conservadas en el freezer a $-20{ }^{\circ} \mathrm{C}$ sumergidas en ARN later (Invitrogen) hasta su posterior uso (10 $\mu \mathrm{l} / \mathrm{mg}$ tejido).

El ARN se obtuvo mediante dos métodos: extracción con Trizol (Invitrogen) y con un kit comercial RNeasy Midi (QIAGEN) siguiendo las indicaciones del proveedor.

Para la extracción de ARN con Trizo/se homogeneizaron 100 mg de glándula del albumen en $1 \mathrm{ml}$ de Trizol y 0,22 $\mathrm{ml}$ de cloroformo. Se agitaron los tubos vigorosamente por inversión y vórtex, y se centrifugaron a 12.000 xg durante 10 $\min a 4^{\circ} \mathrm{C}$ conservando la fase acuosa superior.

La fase acuosa se transfirió a un tubo nuevo y el ARN se precipitó con 0,5 $\mathrm{ml}$ de isopropanol, incubando durante $30 \mathrm{~min} \mathrm{a}-20{ }^{\circ} \mathrm{C}$. Posteriormente se centrifugó a $12.000 \times g$ durante $10 \mathrm{~min}$, el sobrenadante se descartó y el precipitado que contenía el ARN se lavó dos veces con etanol 70 \% y se dejó secar unos minutos. El ARN total obtenido se resuspendió en agua con DEPC y se almacenó $\mathrm{a}-20^{\circ} \mathrm{C}$ hasta su empleo.

El método que obtuvo mejor pureza de ARN, aunque menor concentración, fue el Kit comercial (ver resultados en capítulo 4).

3.5.3 Electroforesis en gel desnaturalizante de ARN (Sambrook et al., 1989)

EI ARN total obtenido se analizó para corroborar su integridad en geles de agarosa en condiciones desnaturalizantes. La desnaturalización del ARN garantiza 
que la movilidad electroforética sea en función de su peso molecular, evitando la tendencia a formar estructuras secundarias intracatenarias.

Soluciones utilizadas:

- Buffer de electroforesis (MOPS 10x): 200 mM MOPS (ácido 4-morfolino propanosulfónico), $50 \mathrm{mM}$ acetato sódico, $10 \mathrm{mM}$ EDTA llevado a pH 7,0 con $\mathrm{NaOH}$.

- Buffer muestra desnaturalizante: 62,5\% formamida, $25 \%$ formaldehído, $12,5 \%$ MOPS $10 x$.

- Buffer de carga: $50 \%(v / v)$ glicerol, 0,25\% (p/v) cianol xileno, 0,25\% (p/v) azul de bromofenol.

La relación entre buffer muestra y de carga es 4:1.

La muestra de ARN $(10 \mu \mathrm{g})$ se preparó en buffer muestra con el volumen correspondiente de buffer de carga, y se desnaturalizó calentando 10 min a $65^{\circ} \mathrm{C}$. Para visualizar el ARN se incorporó bromuro de etidio directamente a la muestra (1 $\mu$ de stock $10 \mathrm{mg} / \mathrm{ml}$ ).

Se cargó la muestra de ARN desnaturalizado en un gel de agarosa 1,2 \% y formaldehído 6,3 \% (en MOPS 1x). La electroforesis se realizó a $120 \mathrm{~V}$ en buffer MOPS $1 x$ y se comprobó el estado del ARN y la carga visualizando las bandas bajo luz ultravioleta en un transiluminador.

La concentración del ARN obtenido se determinó mediante espectrofotometría, midiendo su absorbancia a $260 \mathrm{~nm}(1 \mathrm{~A}=40 \mu \mathrm{g} / \mathrm{ml})$. También se estimó el grado de impurezas de origen proteico a partir del cociente $A_{260} / A_{280}$ empleando los que tuvieran valores entre 1,7 y 2 para asegurar su alta pureza.

\subsubsection{Transcripción reversa (RT)}

Es el proceso por el cual se sintetiza una cadena de ADN complementaria $(A D N c)$ a partir de un ARN molde, mediante la utilización de la enzima transcriptasa reversa.

Se utilizó un kit comercial (Omniscript Reverse Transcription, QIAGEN) que permite realizar la síntesis del ADNc a partir de mRNA utilizando oligo(dT) 
como cebadores. Se agregaron $2 \mu \mathrm{g}$ de ARN total, $1 \mu \mathrm{M}$ de oligonucleótidos (Invitrogen), $2 \mu$ de buffer RT 10x (QIAGEN), $2 \mathrm{mM}$ de desoxinucleótidos trifosfatados (dNTPs), 10 unidades de inhibidor de ARNasas, 4 unidades de la enzima Omniscript-RT y agua DEPC hasta un volumen final de $20 \mu$. Se mezcló e incubó la muestra $1 \mathrm{~h}$ a $37^{\circ} \mathrm{C}$.

\subsubsection{Diseño de primers degenerados}

Los oligonucleótidos empleados para amplificar la subunidad menor de PV2 se diseñaron en base a la secuencia peptídica de fragmentos trípticos obtenidos por ESI-MS-MS en el Instituto Max-Planck de Biofísica Química (Goettingen,

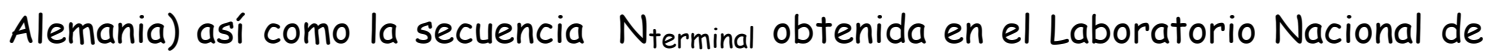
Investigación y Sevicios en péptidos y proteínas (LANAIS-PRO, Universidad de Buenos Aires - CONICET) (tabla 1.2).

Se utilizó el programa Gene Runner para determinar la temperatura de fusión de los oligonucleótidos y evaluar la presencia de estructuras secundarias. También se utilizó el programa Codon Usage para priorizar en el diseño de la secuencia los tripletes mas conservados en especies relacionadas.

Finalmente se enviaron a sintetizar los oligonucleótidos a Productos BioLógicos (PB-L, U.N.Quilmes).

Tabla 1.2: Secuencias de péptidos obtenidos por tratatamiento con tripsina y secuenciación del Nt. En la última columna se listan las secuencias de oligonucleótidos diseñados a partir de dichos péptidos.

\begin{tabular}{ccc}
\hline Primer & Secuencia peptídica & Secuencia nucleotídica \\
\hline Tríptico 1 & QANPVGG & f 5' CARGCNAAYCCNGTNGGNGG 3' \\
Tríptico 2 & GPAGVW & f 5' GGNCCNGCNGGNGTNTGG 3' \\
Nterminal & MPRDEHW & f 5' ATGCCNMGNGAYGARCAYTGG 3' \\
PoliT & & $f 5^{\prime}$ GCGGATCCTTTTTTTTTTTTTTTTTTTV 3' \\
\hline
\end{tabular}

Referencias: En rojo se marcan los nucleótidos degenerados, $R$ : bases púricas $(A-G)$, Y: bases pirimídicas $(T-C), N$ : todas las bases, $M: A-C, V: A-G-C$. En azul se muestra la secuencia de reconocimiento de enzimas de restricción. 
3.5.6 Reacción en cadena de la polimerasa (PCR)

Se utilizaron los oligonucleótidos iniciadores o "primers" previamente descriptos, complementarios a una de las hebras de la doble hélice y un oligonucleótido polit que tiene incluído un sitio de restricción para las enzimas (color azul de la tabla 2) para amplificar al ADNc desde su extremo 5' al 3'.

Se realizó la amplificación del ADNc de la subunidad menor de la proteína mediante PCR utilizando como molde 2,5 $\mu$ l del producto de RT-PCR (50-100 ng de ADN) para cada grupo de oligonucleótidos. La reacción se hizo en un volumen final

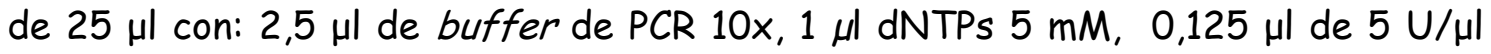
Taq Platinium ADN polimerasa (Invitrogen), 0,75 $\mu \mathrm{l}$ de $\mathrm{MgCl} 250 \mathrm{mM}, 0,75 \mu \mathrm{l}$ de oligonucleótidos degenerados $10 \mu \mathrm{M}, 0,75 \mu$ de polit $10 \mu \mathrm{M}$ y agua libre de nucleasas.

Las muestras se amplificaron de la siguiente forma: $30-35$ ciclos de: 30 seg a $94{ }^{\circ} \mathrm{C}$ (temperatura de desnaturalización), 30 seg a Tm (temperatura de apareamiento correspondiente a cada juego de primers), $1 \min$ a $72{ }^{\circ} \mathrm{C}$ (temperatura de extensión); precedidos por una desnaturalización del ADN molde de 3 minutos a $94{ }^{\circ} \mathrm{C}$ y una extensión final a $72{ }^{\circ} \mathrm{C}$ por $7 \mathrm{~min}$ (Sambrook et al., 1989).

\subsubsection{Electroforesis en geles de agarosa}

Las moléculas de ADN son forzadas a migrar a través de una matriz de agarosa por la aplicación de un campo eléctrico. Los fragmentos más pequeños migran más rápido que los de mayor tamaño y, la distancia recorrida en el gel es inversamente proporcional al logaritmo del peso molecular del fragmento. El tamaño se determinó utilizando un marcador de pesos moleculares conocidos, en nuestro caso Loading invitrogen track/t $1 \mathrm{~kb}$ (Invitrogen).

Para la preparación de los geles se utilizó agarosa ultrapura (Invitrogen) a una concentración de $2 \%(\mathrm{p} / \mathrm{v}$ ) disuelta en buffer TBE (Tris 0,05 M; acido bórico $0,05 \mathrm{M}$; EDTA-Na $\mathrm{Na}_{2} 2 \mathrm{H}_{2} \mathrm{O} 1 \mathrm{mM} \mathrm{pH} \mathrm{8,0).} \mathrm{Las} \mathrm{corridas} \mathrm{electroforéticas} \mathrm{se} \mathrm{realizaron}$ en una cuba horizontal (Hoeffer HA 33, Amersham Biosciences) utilizando TBE como 
buffer de corrida. Se continuó la separación a $100 \mathrm{~V}$ hasta que el frente hubiera recorrido aproximadamente el $80 \%$ del tamaño del gel.

Las bandas de ADN se visualizaron en un transiluminador UV (Hoeffer MacroVue UV-20) previa tinción de los geles con una solución de bromuro de etidio $(0,5 \mu \mathrm{g} / \mathrm{ml})$. Para realizar el análisis, los geles se fotografiaron utilizando una cámara digital KD120 (Kodak) y se analizaron con el software Kodak Digital Science 10 (Kodak).

Para la cuantificación de las muestras de ADN se midió la absorbancia a 260 nm y en el cálculo de su concentración se consideró la posible contaminación de la muestra con proteínas (lectura a $280 \mathrm{~nm}$ ) o con fenol (lectura a $230 \mathrm{~nm}$ ) realizando las correcciones correspondientes.

\subsubsection{Aislamiento y purificación de fragmentos de PCR}

Los fragmentos amplificados se analizaron en un gel de agarosa $1 \%$ de bajo punto de fusión, se cortaron las bandas de interés, se pesaron y su ADN fue purificado con el kit comercial Gel extraction (QIAGEN).

El ADN de interés se clonó en el vector pGEM-T easy (Promega); las reacciones de ligazón se realizaron con la enzima T4 ADN ligasa ( $1 \mathrm{U} / \mu \mathrm{g}$ ADN) utilizando una relación molar inserto:vector de 3:1. La mezcla se incubó a $4{ }^{\circ} \mathrm{C}$ toda la noche y el resultado de esta ligazón se utilizó para transformar bacterias competentes.

Las bacterias competentes utilizadas fueron E. coli JM 109 obtenidas por el método descripto por Inoue (1990).

El plásmido se introdujo en las bacterias mediante shock térmico, adicionando aproximadamente $10 \mathrm{ng}$ de ADN plasmídico a $200 \mu \mathrm{l}$ de suspensión de bacterias competentes e incubando en hielo durante $30 \mathrm{~min}$, luego se transfirió el tubo a un baño de agua a $42{ }^{\circ} \mathrm{C}$ durante 90 seg e inmediatamente se colocó en hielo y se le agregó $0,8 \mathrm{ml}$ de medio SOC (20 g de triptona bacteriológica, $5 \mathrm{~g}$ de extracto de levadura, $5 \mathrm{~g}$ de $\mathrm{Na} \mathrm{Cl}$, glucosa $20 \mathrm{mM}$ ), se llevó al volumen de un litro y se esterilizó por filtración (Sambrook et al., 1989). 
Luego de incubar a $37^{\circ} \mathrm{C}$ durante $1 \mathrm{~h}$, las bacterias se sembraron en placas de LB agar con el antibiótico ampicilina $(100 \mu \mathrm{g} / \mathrm{ml}$ de medio de cultivo) y se esparcieron sobre ellas $100 \mu$ de isopropil- $\beta$-D-1-tiogalactopiranósido (IPTG) 100 $m M$ y $20 \mu l$ de bromo-cloro-indolil- $\beta$-D-galactopiranósido (X-gal) 50 mg/ml, se dejó la placa a temperatura ambiente por $1 \mathrm{~h}$, para luego incubarla a $37^{\circ} \mathrm{C}$ durante toda la noche para que desarrollaran las colonias transformantes. La selección de transformantes se realizó con la resistencia de las bacterias al antibiótico; los clones positivos se seleccionaron por el método de colonias blancas y azules dado que el sitio de clonado interrumpe el gen Lac $Z$ cuyo producto metaboliza el $X$-gal produciendo un metabolito de color azul. Se seleccionaron alrededor de 10 colonias blancas (con inserto) que se incubaron en medio LB líquido con antibiótico durante la noche.

La obtención de plásmidos a partir de bacterias se realizó a pequeña escala (miniprep) utilizando métodos basados en la lisis alcalina con SDS para producir la liberación del plásmido de las bacterias. Se utilizaron dos técnicas, una de bajo costo preparada en el laboratorio (Sembrook \& Russell, 2001) para verificar ausencia de contaminación y otra mediante un kit comercial (QIAprep miniprep, QIAGEN) utilizado para obtener plásmidos con una pureza adecuada para su secuenciación.

Para comprobar la presencia del inserto en las colonias seleccionadas se utilizó la enzima de restricción EcoRI (Promega); se mezclaron 1-3 $\mathrm{\mu g}$ de ADN

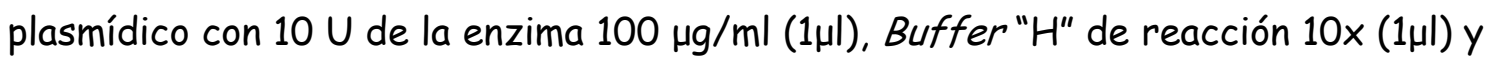
agua libre de nucleasas (c.s.p $10 \mu l)$. Se incubó esta mezcla a $37^{\circ} \mathrm{C}$ durante $1-2 \mathrm{~h}$ y luego se adicionaron $2 \mu$ de buffer para siembra en gel 6x (glicerol $50 \% \mathrm{v} / \mathrm{v}$ en buffer TAE 1x: Tris 0,04 M; Na.acetato. $3 \mathrm{H}_{2} \mathrm{O} 0,02 \mathrm{M}$; EDTA-Na $\mathrm{Na}_{2} 2 \mathrm{H}_{2} \mathrm{O} 1 \mathrm{mM}$; pH 7,2; azul de bromofenol $1 \% \mathrm{p} / \mathrm{v}$; xileno-cianol $1 \% \mathrm{p} / \mathrm{v}$ ). Se visualizó el resultado mediante electroforesis de agarosa 0,8 \% (p/v) (Sambrook et al., 1989).

Las muestras obtenidas, aproximadamente 5 minipreps de cada plásmido, se mandaron a secuenciar al Servicio de Secuenciación y Genotipado de la Facultad de Ciencias Exactas y Naturales, Universidad de Buenos Aires y a Macrogen Inc 
(Corea). Para la secuenciación se utilizaron los oligonucleótidos comerciales SP6 y T7.

\subsubsection{Amplificación rápida de extremos de ADNc (RACE)}

Los fragmentos de ADN obtenidos en las diferentes reacciones de amplificación fueron utilizados para el diseño de cebadores que amplificaran todo el marco de lectura del ADNc de la subunidad menor mediante la técnica de RACE. Para ello se utilizó el kit RLM-RACE (Ambion) que permite la rápida amplificación de los extremos $3^{\prime}$ y $5^{\prime}$ del ADNc amplificado por PCR, obteniendo así el ADNc completo.

Partiendo del ARN total, se obtuvieron los ADNc 5' y 3', que se amplificaron por PCR utilizando cebadores específicos del fragmento que se querían amplificar (zona conocida).

Los cebadores utilizados fueron los siguientes:

\begin{tabular}{cc}
\hline Primer & Secuencia nucleotídica \\
\hline Race 3' Outer & $5^{\prime}$ CTAGCCGCATAACCAACTG 3' \\
Race 5' Outer & 5' CCCGAGTCCACCAAGATCCAATC 3' \\
Race 5' Inner & 5' GGTGATCCAGGTACCGGAGCCACCAGTGGTAACAG 3' \\
\hline
\end{tabular}

\subsection{Técnicas aplicadas a estudios biofísicos}

\subsubsection{Espectroscopía de absorción UV}

La espectroscopía de absorción UV-visible involucra la absorción de luz UVvisible por parte de una molécula, promoviendo el paso de un electrón desde un orbital molecular fundamental a un estado excitado. La separación energética entre estos orbitales corresponde a las longitudes de onda del UV-visible.

La cantidad relativa de luz absorbida por una muestra (absorbancia) está relacionada con la concentración de la especie absorbente, el camino óptico y el 
coeficiente de extinción de la especie a través de la Ley de Lambert-Beer $(A=C . L . \varepsilon)$ donde $A$ es la absorbancia, $C$ la concentración de la muestra, $L$ el camino óptico y $\varepsilon$ coeficiente de extinción molar de la especie absorbente.

Los espectros se realizaron en un espectrofotómetro 550 Jasco, a una velocidad de $40 \mathrm{~nm} / \mathrm{min}$ con una resolución espectral de $1 \mathrm{~nm}$.

La muestra utilizada en los experimentos UV-Visible fue PV2 1,2 $\mu \mathrm{M}$ diluida en buffer fosfato (Pi) $20 \mathrm{mM} \mathrm{NaCl} \mathrm{pH} \mathrm{7,0} \mathrm{ubicada} \mathrm{en} \mathrm{una} \mathrm{celda} \mathrm{de} \mathrm{cuarzo} \mathrm{de} 0.5$ $\mathrm{ml}$ de capacidad y un camino óptico de $1 \mathrm{~cm}$. Realizamos series de diez espectros entre 340 y $240 \mathrm{~nm}$ para cada muestra y cinco espectros para el blanco. Los espectros individuales fueron promediados y corregidos tanto por el blanco como por la dispersión de luz.

Se estudió el entorno conformacional de los residuos aromáticos de PV2 mediante el análisis de cuarta derivada de espectros de absorción UV. Los datos fueron suavizados dos veces con el algoritmo de promediado adyacente, utilizando una ventana de cinco puntos (Press et al., 1988) antes de hacer los cálculos de derivada de cada espectro (Knocker \& Dol, 1992).

\subsubsection{Espectroscopía de fluorescencia}

- Fundamentos generales (Lakowicz, 1999)

Todas las moléculas poseen un conjunto de niveles de energía electrónicos, que desempeñan un rol preponderante en los procesos fotofísicos ( $S_{0}$ estado singlete del nivel fundamental, $S_{1}$ estado singlete del primer estado excitado y $T_{1}$ estado triplete del primer estado excitado). A su vez, cada uno de estos niveles electrónicos presenta subniveles vibracionales.

Los procesos fotofísicos se definen como transiciones que interconvierten estados excitados entre sí o estados excitados con el nivel fundamental.

Una vez producido el salto entre el estado fundamental y el estado excitado hay muchas vías posibles de des-excitación y la más favorable dependerá del tipo de molécula, de las condiciones físico-químicas en las cuales se encuentra y de la 
naturaleza de los estados excitados implicados. Estas vías o procesos se pueden clasificar en tres categorías bien diferenciadas:

1. Procesos radiativos, que implican la emisión de radiación electromagnética.

2. Procesos no radiativos, en los que la población del estado inicialmente excitado se transfiere a otro estado sin que la acompañe ninguna emisión.

3. Procesos de quenching, en los cuales la des-excitación implica la transferencia de energía de la molécula inicialmente excitada a otras partículas presentes en el sistema (formalmente un proceso no-radiativo).

Una de las propiedades más interesantes de las moléculas electrónicamente excitadas es su tendencia a emitir radiación (proceso radiativo) para volver al estado fundamental. Se pueden distinguir dos tipos de transiciones radiativas: la fluorescencia y la fosforescencia.

La fluorescencia es la emisión que resulta del regreso de un electrón desde un estado excitado a su nivel fundamental y la velocidad de emisión es del orden de $10^{8} \mathrm{seg}^{-1}$. La fosforescencia es la emisión resultante del retorno generalmente de estados excitados tripletes a estados fundamentales singletes e involucra tiempos de des-excitación muy largos (del orden de los microsegundos) en comparación con la fluorescencia.

En la figura 3.3 (conocida también como diagrama de Jablonski) se ilustra la absorción y emisión de luz. La absorción ocurre en el orden de $10^{-15} \mathrm{seg}$, un tiempo demasiado corto para que se produzca un desplazamiento significativo del núcleo, lo que implica que el fluoróforo es generalmente excitado a algún nivel vibracional superior de $S_{1} \circ S_{2}$. Típicamente se produce una relajación de este nivel vibracional a niveles vibracionales inferiores de $S_{1}$, proceso que se llama conversión interna y que generalmente ocurre en $10^{-12} \mathrm{seg}$. Así, los fotones emitidos en el proceso de fluorescencia (que sigue a la relajación vibracional) son de menor energía que los absorbidos, con lo cual la longitud de onda de emisión siempre será mayor que la longitud de onda de excitación. La diferencia entre ambos valores se conoce como corrimiento de Stokes. 
Figura 1.3: Diagrama de Jablonski

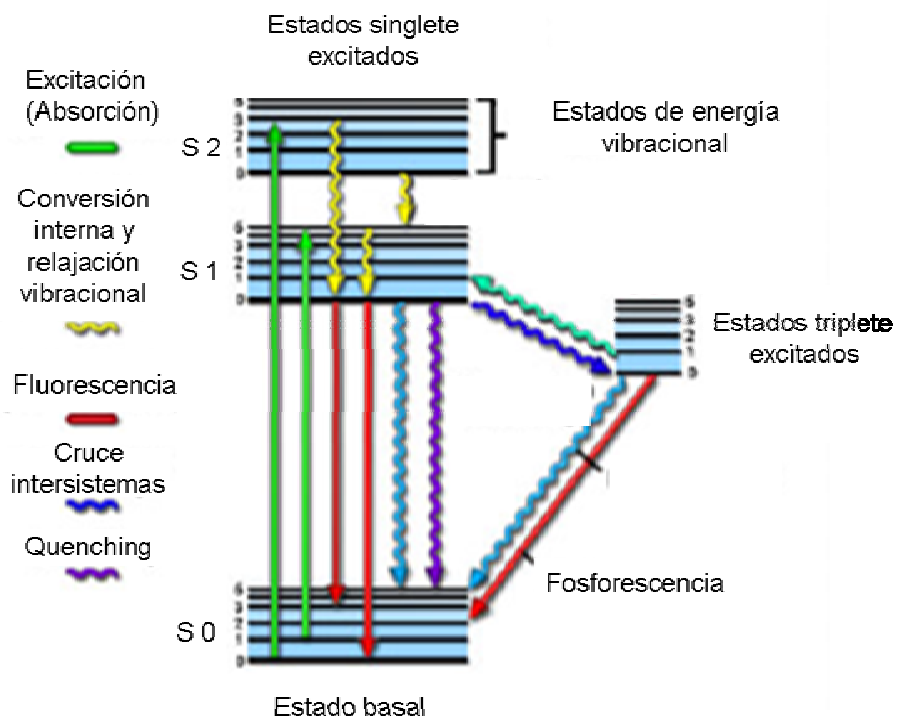

La intensidad de emisión como función de la longitud de onda (espectro de fluorescencia) dependerá de la estructura química del fluoróforo, del solvente y de las características fisicoquímicas del entorno en el cual se encuentre.

- Fluorescencia de proteínas

La fluorescencia en proteínas es una herramienta excelente para evaluar sus cambios conformacionales y es el resultado de la presencia de fluoróforos naturales en su estructura como los aminoácidos aromáticos fenilalanina (Phe), tirosina (Tyr) y triptofano (Trp).

El Trp es un muy buen fluoróforo, debido a su alto rendimiento cuántico y a su grupo indol altamente sensible a la polaridad del solvente; por ello el espectro de emisión de los residuos Trp refleja la polaridad del entorno que lo rodea. Para Trp ubicados en entornos muy hidrofóbicos, el máximo del espectro de emisión se sitúa en $320 \mathrm{~nm}$ aproximadamente y su rendimiento cuántico (reflejado en la intensidad del espectro) aumenta. Si se encuentra ubicado en un entorno polar (como en la proteína desplegada) el máximo se desplaza a $350 \mathrm{~nm}$ pudiendo reducirse la intensidad de emisión debido a colisiones con las moléculas del 
solvente. Así, se puede seguir el curso del desplegado proteico midiendo el corrimiento en el máximo de emisión de los residuos de Trp.

Los espectros de fluorescencia de PV2 se obtuvieron utilizando un espectrofluorímetro Olis-upgraded SLM 4800 (Bogart, GA). El Trp fue excitado a $270 \mathrm{~nm}$ con un ancho de banda de $4 \mathrm{~nm}$ (tanto en la rama de excitación como en la de emisión) y se registró su emisión entre 310 y $410 \mathrm{~nm}$. Todos los experimentos se realizaron en buffer Pi $20 \mathrm{mM} \mathrm{pH} \mathrm{7,0} \mathrm{con} 50 \mathrm{mM}$ de $\mathrm{NaCl}$ (con una concentración de PV2 de 1,2 $\mu \mathrm{M}$ ) en cubetas de cuarzo con un paso óptico de $5 \mathrm{~mm}$.

Se tomaron espectros de emisión de fluorescencia de PV2 en su forma nativa y desplegada a diferentes valores de $\mathrm{pH}$, concentración de urea y temperatura tal como se describirá en cada uno de los experimentos.

- Quenching de fluorescencia

La intensidad de fluorescencia puede disminuir por varios procesos que se denominan, de manera genérica, "quenching" o "apagamiento" de la fluorescencia y ocurre cuando parte de los fluoróforos excitados vuelven al estado basal sin emitir fotones debido al contacto con la molécula "quencher" o "apagadora". Entre muchos otros se pueden distinguir dos mecanismos importantes de quenching:

1) Quenching dinámico o colisional: Cuando la molécula en su estado excitado le transfiere energía al quencher al colisionar con ella.

2) Quenching estático: Cuando el fluoróforo en su estado fundamental forma un complejo con el quencher, el cual se relaja por procesos que no emiten fotones.

En una primera aproximación, la intensidad de fluorescencia en presencia de una concentración de quencher (Q) se calcula mediante la ecuación de SternVolmer: $F o / F=1+K[Q]$, donde Fo es la intensidad del fluoróforo en ausencia del quencher, $F$ es la intensidad en presencia de una concentración [Q] del quenchery $K$ la constante de quenching.

La eficiencia y el mecanismo específico de quenching dependen del fluoróforo y del propio quencher. Un quencher típico utilizado para estudiar la 
fluorescencia del Trp es la molécula de acrilamida que presenta una alta solubilidad en buffers acuosos y cuya carga neta es cero, eliminando efectos de carga originados en la densidad electrónica del solvente o del entorno local del Trp.

Se empleó una solución de proteína (PV2) cuya concentración inicial era de $1,2 \mu \mathrm{M}$ y se fueron agregando cantidades crecientes de acrilamida a partir de una solución madre 1,5 M disuelta en buffer $\mathrm{Pi}$ con el fin de alcanzar finalmente una concentración de quencher de $1 \mathrm{M}$.

El Trp se excitó a 280 nm y se registró su emisión entre 305 y 445 nm de longitud de onda. Los datos fueron corregidos por la dilución de la proteína.

El tratamiento matemático del quenching y su accesibilidad son explicados y desarrollados en la sección de resultados.

- Cuantificación de cisteínas

Para determinar la cantidad de cisteínas totales presentes en PV2 se utilizó una sonda fluorescente llamada monobromobimano ( $m B r B$, Fluka) (cuyo rendimiento cuántico aumenta sensiblemente al formar una unión S-S con los residuos de cisteína de la proteína) y se registró su espectro de emisión siguiendo la metodología de Kosower y Kosower (1995). Brevemente, se utilizaron $10 \mu$ de una solución $100 \mu \mathrm{M}$ de $\mathrm{mBrB}$ disuelto en acetonitrilo, agregada a $520 \mu \mathrm{l}$ de una solución de PV2 en buffer fosfato $20 \mathrm{mM} \mathrm{pH} \mathrm{7,2.} \mathrm{Por} \mathrm{otra} \mathrm{parte,} \mathrm{se} \mathrm{utilizó} \mathrm{esa}$ misma cantidad de sonda, pero utilizando PV2 expuesta a diferentes concentraciones de urea (agente desnaturalizante) para lograr una concentración final de $0,025 \mu \mathrm{M}$ PV2 y $1.88 \mu \mathrm{M} \mathrm{mBrB}$.

Las muestras fueron incubadas durante toda la noche anterior a las mediciones de fluorescencia.

Se utilizó como muestra control una solución de BSA $(0.025 \mu M$ en urea 8 M, bufferPi $20 \mathrm{mM}, \mathrm{pH} 7,2)$ cuya cantidad total de cisteínas era conocida.

El número de cisteínas expuestas al medio fue determinado comparando los espectros de emisión de la muestra y del control. 


\subsubsection{Dicroísmo circular de luz UV (CD)}

Esta técnica se emplea para medir la actividad óptica de moléculas asimétricas en solución. Brinda información respecto a la diferente absorción de radiación electromagnética circularmente polarizada. Cuando la absorción por parte de la especie ópticamente activa se hace importante, la solución presenta dicroísmo circular y la luz emerge de la solución con polarización elíptica. Para describirla se suele utilizar un parámetro denominado elipticidad $(\theta)$, que es la magnitud que miden los espectropolarímetros (Freifelder, 2003).

El espectro de CD de una proteína ocurre en dos regiones que nos brindan diferente información acerca de la estructura de una proteína:

- UV-lejano (190-240 nm) dominada por las contribuciones del enlace peptídico, de manera que proporciona información sobre la estructura secundaria de la proteína. En particular, la a-hélice muestra un espectro fuerte y característico de una banda negativa con dos mínimos (222 y $208 \mathrm{~nm}$ ) y una banda positiva con un máximo a $190 \mathrm{~nm}$. Las hojas beta en cambio presentan un mínimo a 217 y un máximo a $195 \mathrm{~nm}$; mientras que si tiene una estructura desordenada, el espectro muestra una banda positiva a 212 y una negativa a $195 \mathrm{~nm}$.

Es posible representar el espectro de $C D$ en el UV-lejano $(f C D)$ de cualquier proteína como una combinación lineal de contribuciones de las diferentes estructuras secundarias presentes.

- UV-cercano (260-320 nm) dominado por contribuciones de aminoácidos aromáticos. La región UV-cercano ( $n C D)$ muestra señal cuando en una proteína plegada, dichos aminoácidos están inmovilizados en un entorno asimétrico. Por ello, estos espectros son muy sensibles para determinar el estado nativo de una proteína, siendo la señal en esta región virtualmente cero en una proteína desnaturalizada.

Se registraron espectros de $f C D$ y $n C D$ con un espectropolarímetro Jasco J-810 (Jasco Corp., Japón) utilizando un ancho de banda de 0,5 nm, velocidad de barrido de $100 \mathrm{~min}^{-1}$ y tiempo de integración espectral de $4 \mathrm{seg}$. Se utilizaron cubetas de cuarzo de $0,1 \mathrm{~cm}(f C D) \circ 1 \mathrm{~cm}(n C D)$ en celdas termostatizadas a $20^{\circ} \mathrm{C}$. 
Se trabajó con la proteína PV2 disuelta en buffer Pi $20 \mathrm{mM}, \mathrm{pH} 7,4$ con una concentración final de 0,15 $\mu \mathrm{M}(f C D)$ o bien en el mismo buffer pero con una concentración de 1,2 $\mu \mathrm{M}(\mathrm{nCD})$; la absorción en esta región espectral es cerca de dos órdenes de magnitud menor que en el UV lejano. Por esto se utilizó una concentración casi diez veces mayor de proteína. Se realizaron tres espectros para cada muestra que fueron promediados y corregidos por la actividad dicroica del blanco.

El contenido de estructura secundaria fue estimado mediante análisis de la elipticidad molar con los algoritmos K2d (Andrade et al., 1993) y Contin (Provencher \& Glockner, 1981).

Para evaluar la pérdida de conformación helicoidal de PV2 en función de la temperatura se realizaron espectros a una longitud de onda fija de $222 \mathrm{~nm}$ utilizando un elemento calefactor tipo "Peltier" para cambiar de manera continua la temperatura de la muestra a una tasa de $2^{\circ} \mathrm{C} \mathrm{min}^{-1}$ entre 20 a $80^{\circ} \mathrm{C}$.

\subsubsection{Dispersión de rayos $X$ a bajo ángulo (SAXS)}

La técnica de SAXS permite obtener información estructural de macromoléculas en solución. Esta técnica se basa en la determinación del patrón de dispersión angular cuando la muestra es iluminada con radiación monocrómatica en el rango de los rayos-X (típicamente 1-2 $\AA$ ). El estudio de la evolución de los parámetros estructurales asociados a la muestra como función de cualquier variable controlada $(\mathrm{pH}$, fuerza iónica, temperatura, concentración de caótropos, etc.) permite obtener valiosa información sobre la termodinámica del sistema estudiado. En condiciones especiales es posible incluso obtener modelos 3D de baja resolución ( $-5-7 \AA)$ de la macromolécula estudiada.

Los experimentos SAXS se realizaron en la línea D02A-SAXS2 en el Laboratorio Nacional de Luz Sincrotron, Campinas (SP, Brasil).

La solución de proteínas es iluminada con radiación electromagnética que es producida por electrones que se mueven a alta velocidad (cercanas a la de la luz) en un campo magnético (radiación sincrotón). Los fotones dispersados cuando el haz 
impacta con la muestra se registran en función del ángulo al cual fueron dispersados formando así el "diagrama de dispersión SAXS". A partir del ángulo de dispersión y de la longitud de onda del haz incidente se calcula el valor del módulo del vector de impulso transferido $(q), q=4 \pi \operatorname{sen} \theta / \lambda$.

En nuestro caso específico, la curva SAXS se registró en forma de imagen mediante un detector bidimensional tipo MARCCD y la curva de intensidad de radiación I como función de $q(I(q))$ fue obtenida usando el software de distribución libre FIT 2D (Hammersley, 1997; http://www.esrf.fr /computing /scientific/FIT2D).

Se midió la dispersión de rayos $X$ a bajo ángulo de PV2 nativa así como desnaturalizada por distintos agentes. El haz de fotones monocromático (longitud de onda de $1,488 \AA$ ) fue obtenido con un monocromador con focalización horizontal y un espejo para focalización vertical. Se utilizaron celdas capilares de cuarzo de $1 \mathrm{~mm}$ de camino óptico para rayos-X y la muestra fue ubicada a $1044 \mathrm{~mm}$ de distancia del detector permitiendo un rango nominal de q entre 0,012 y 0,25 $\AA^{-1}$. Esto permite determinar parámetros estructurales con un tamaño máximo $\left(D_{\max }\right)$ nominal $\leq 260 \AA$.

Todas las medidas fueron corregidas por la intensidad del haz, la homogeneidad del detector, "ruido" intrínseco del detector y absorción de la muestra siguiendo los procedimientos habituales.

Para cada experimento individual se promediaron al menos tres medidas. La concentración de proteína y las condiciones de la muestra se describen en la sección correspondiente. La temperatura se controló mediante un baño de agua y las muestras fueron calentadas empezando por $20^{\circ} \mathrm{C}$ y llegando a una temperatura de $70^{\circ} \mathrm{C}$.

El tamaño de PV2 se determinó a partir del cálculo del radio de giro $\left(R_{G}\right)$ obtenido por linearización de la región de bajo q, conocida como "región de Guinier": el comportamiento general de cualquier curva SAXS a bajo $q$ permite suponer que $\ln (I)=\ln \left(I_{0}\right)-\left(R_{G} q^{2} / 3\right)$ (Svergun \& Koch, 2003). 
La "globularidad" de PV2 (entendiendo como "globular" una estructura "colapsada" o "plegada") fue determinada usando la representación de Kratky $\left(I(q)^{\star} q^{2}\right.$ vs. $\left.q\right)$ del diagrama SAXS. Se puede demostrar que la curva de Kratky debe tener forma de "campana" para un objeto globular mientras que para una cadena "estadística" (similar a lo esperado para una proteína desnaturalizada) debe tener una forma aproximadamente "sigmoidea" (Svergun \& Koch, 2003).

La distribución de pares de distancia $P(r)$ obtenidos a partir de datos de dispersión representa las frecuencias de las distancias entre elementos de pequeño volumen dentro de la partícula dispersante, llegando a un valor de cero cuando se alcanza la dimensión máxima de la molécula. Esta distribución fue calculada utilizando el programa GNOM 4.5 que implementa el método de la Transformada de Fourier Regularizada (Svergun, 1992).

El modelo de baja resolución de PV2, que representa la forma de la partícula de dispersión, se obtuvo con el programa DAMMIN 5.3 (Svergun, 1999) que utiliza un procedimiento de optimización estructural basado en la técnica de annealing simulado. Con el fin de garantizar la relevancia estadística del modelo obtenido por DAMMIN 5.3, 15 simulaciones independientes fueron alineadas y promediadas utilizando el método implementado en el paquete de programas DAMAVER (Volkov \& Svergun, 2003).

\subsubsection{Microscopía electrónica de transmisión (MET)}

En lugar de luz visible, el microscopio electrónico utiliza electrones para formar imágenes de un objeto. Dado que los electrones tienen una longitud de onda mucho menor que la de la luz pueden mostrar estructuras mucho más pequeñas. La longitud de onda de los electrones que se utilizan en los microscopios electrónicos es de alrededor de 0,5 . Esta técnica permite realizar la identificación morfológica de las partículas proteicas con aceptable resolución de detalles.

El Microscopio Electrónico de Transmisión (MET) permite la observación de muestras en cortes ultrafinos. Consiste en un largo tubo, en cuyo interior se coloca un filamento de tungsteno que funciona como cátodo. Éste provoca, al ser excitado 
por un ánodo situado bajo él, un haz de electrones al que se lo hace pasar por un sistema condensador. El haz condensado incide sobre el objetivo, en el cual está colocada la muestra. Los electrones que la sobrepasen serán proyectados hacia una pantalla fluorescente situada en el fondo del tubo. Por lo tanto, la imagen que se ve es la proyección de un chorro de electrones sobre una pantalla fluorescente. Todos estos procesos se realizan con el vacío hecho en el tubo, para la correcta transmisión de los electrones (Hayat, 1986).

Las muestras se contrastaron mediante la tinción negativa con ácido fosfotúngstico, una técnica sencilla, económica y de uso generalizado para contrastar muestras particuladas. El contraste se obtiene embebiendo la partícula a observar en una sal de un metal pesado (ácido fosfotúngstico al $2 \%$, acetato de uranilo al $4 \%$ ), que perfila mínimos detalles ultraestructurales sobre un fondo oscuro; de ahí su denominación. Se aplica al estudio de microorganismos (virus, bacterias, protozoarios), fragmentos celulares (membranas) y macromoléculas aisladas (proteínas).

Se utilizó PV2 nativa ( $5 \mu \mathrm{M}$ en buffer Pi) contrastada con $1 \%(\mathrm{p} / \mathrm{v})$ de fosfotungstato de sodio $\mathrm{pH} 7,4$ y secado al aire.

Las imágenes fueron registradas en un microscopio electrónico de transmisión JEM EX-1200 (Tokyo, Japón) y el análisis estadístico de la distribución de tamaños de partículas se llevó a cabo utilizando las herramientas incorporadas en el programa ImageJ 1.36b (http://rsb.info.nih.gov/ij/ rsb.info.nih.gov/ij/).

\subsubsection{Digestión con proteinasa $\mathrm{K}$}

La PV2 nativa fue sometida a digestión con proteinasa $K$ (Promega) suministrada como polvo liofilizado y reconstituido en $50 \mathrm{mM}$ Tris- $\mathrm{HCl}$ pH 8,0, 10 $\mathrm{mM} \mathrm{CaCl}$.

La proteinasa $K$ pertenece a la familia de las serin-proteasas, con una especificidad de amplio rango ya que hidroliza los enlaces peptídicos adyacentes al 
grupo carboxilo de tanto aminoácidos alifáticos como aromáticos. Por esto, se la utiliza para digestión general de proteínas en muestras biológicas.

La PV2 $(1 \mathrm{mg} / \mathrm{ml})$ fue incubada con 1,10 y $100 \mathrm{mg} / \mathrm{ml}$ de proteinasa $\mathrm{K} \mathrm{a} 37^{\circ} \mathrm{C}$ durante $30 \mathrm{~min}$. La digestión se detuvo hirviéndola en buffer muestra SDS con B-ME y los productos de la digestión fueron analizados en un gel SDS-PAGGE 4-20\% (descripto en sección 3.3).

\subsection{Ensayos de toxicidad}

\subsubsection{Determinación de LD50 en ratones}

Se utilizaron ratones hembra Balb-C de cuatro semanas de edad con un peso de 19-21 g provenientes de una colonia proporcionada por el NIH (USA) y criados en un ambiente libre de patógenos (grado SPF) provistos por el bioterio de la Facultad de Ciencias Veterinarias (UNLP). Todos los estudios se realizaron de acuerdo con la guía para el cuidado y uso de los animales de laboratorio (National Research Council, 1996).

Grupos de diez ratones fueron inyectados vía intraperitoneal (i.p) con una dosis única de $300 \mu$ de PBS o el mismo volumen de la toxina en cinco diluciones seriadas ya sea de fracción soluble de huevo o de PV2 purificada.

Se determinó así la dosis letal 50 (LD50) a las 96 h luego de la inyección. El análisis estadístico para establecer LD50 con límites de confianza del $95 \%$ se realizó mediante PROBIT empleando el programa Toxdat (US, EPA).

\subsubsection{Ensayo de toxicidad de lípidos}

Los lípidos presentes en la fracción soluble de huevo fueron extraídos con cloroformo: metanol siguiendo el método de Bligh y Dyer (1959). El extracto lipídico obtenido a partir de $50 \mathrm{mg}$ de huevo fue disuelto en $20 \mu \mathrm{ll}$ de dimetilsulfóxido (DMSO) y $300 \mu$ de PBS e inoculado vía i.p a ratones. 
Se empleó como control negativo un grupo de ratones que sólo recibieron DMSO en PBS.

\subsubsection{Determinación de la susceptibilidad térmica}

La toxina purificada PV2 se hirvió a $100{ }^{\circ} \mathrm{C}$ durante 15 min y posteriormente se evaluó su actividad tóxica mediante inyección i.p en ratones (1 mg/kg). Se inyectó un grupo de cinco ratones y otro grupo control que recibió igual volumen de PBS.

\subsubsection{Inmunización de ratones}

Para comprobar si los ratones eran capaces de inmunizarse contra la toxina, los animales fueron inoculados vía i.p con dosis subletales de $3 \mu \mathrm{g}$ de PV2 purificada y pasados 19 días se realizó una segunda inyección de $30 \mu \mathrm{g}$ en PBS sin utilizar adyuvantes. El suero se extrajo cuatro días después y se mantuvo a $-70{ }^{\circ} \mathrm{C}$ hasta su posterior uso y análisis.

\subsubsection{Histopatología}

Grupos de seis ratones fueron inyectados con una dosis de PBS (grupos control) o con PV2, $1 \mathrm{mg} / \mathrm{kg}$ (19 $\mu \mathrm{g}$ de PV2 por ratón).

Después de $40 \mathrm{~h}$ los animales fueron anestesiados con una inyección de clorhidrato de ketamina (40 mg/kg i.p.) más xylazina (8 mg/kg, i.m.); luego se realizó una perfusión cardíaca con $50 \mathrm{ml}$ de PBS seguidos por $50 \mathrm{ml}$ de paraformaldehido (PFA) $4 \%$ (p/v) en PBS. Se realizó la disección de los principales órganos: corazón, hígado, riñones, bazo, útero, estómago e intestino, que fueron fijados en formaldehído y posteriormente incluidos en parafina. La médula espinal se retiró cuidadosamente, se mantuvo en formaldehído $3 \mathrm{~h}$ y luego en fijador Bouin tres días.

Secciones representativas de 5-7 $\mu \mathrm{m}$ se tiñeron con hematoxilina-eosina para los exámenes histológicos de la morfología general. Las muestras de tejido 
nervioso en cambio se tiñeron con galocianina para resaltar la morfología nuclear y la sustancia de Nissl.

\subsubsection{Inmunohistoquímica}

La técnica de inmunohistoquímica (IHQ) permite la identificación de la variedad de antígenos presentes en las células o tejidos utilizando anticuerpos marcados con una sustancia que absorbe/emite luz o produce coloración. La aplicación directa de anticuerpos sobre secciones tisulares permite la localización microanatómica precisa con una tinción permanente y estable, permitiendo evaluar con microscopía óptica la presencia del anticuerpo marcado. El empleo de anticuerpos monoclonales permite asimismo aumentar la especificidad, sensibilidad y gama de aplicaciones de esta técnica. En nuestro caso se evaluó la medula espinal.

Se consideraron ocho secciones representativas de la región lumbar, dorsal y cervical de la médula espinal de cada animal, las cuales fueron analizadas por IHQ para evaluar los niveles de la proteína fijadora de calcio calbindina.

Las secciones fueron incubadas con un anticuerpo primario monoclonal de ratón anti-calbindina (Novocastra, USA) en una dilución 1:100 durante toda la noche a $4{ }^{\circ} \mathrm{C}$. Para el revelado se utilizó un kit comercial Envision plus kit (Dako, Carpinteria, CA, USA) basado en un polímero de dextrano acoplado a la enzima peroxidasa.

Las células fueron teñidas con 3,3' diaminobenzidina tetrahidroclorada (DAB) empleando $\mathrm{H}_{2} \mathrm{O}_{2}$ como sustrato de la peroxidasa. La tinción positiva se observa de color marrón oscuro. Todas las secciones estudiadas se contrastaron luego con la tinción hematoxilina de Mayer antes de su análisis. El anticuerpo primario fue sustituido por suero anti-ratón normal en las secciones control.

La apoptosis neuronal analizada mediante IHQ fue revelada mediante la técnica TUNEL en la cual una transferasa reemplaza desoxinucleótidos terminales (TdT) por UTP marcado con biotina para ser posteriormente visualizados usando el kit de detección de apoptosis in situ con peroxidasa Apoptag (Chemicon Internacional, USA.). 
De esta manera puede evidenciarse la fragmentación del ADN en las células apoptóticas debido a que estas generan muchos extremos 3'-OH libres en cadenas simples y dobles de la molécula de $A D N$, los cuales pueden ser rápidamente identificados "in situ" añadiendo nucleótidos químicamente marcados y no marcados con TdT. Los nucleótidos incorporados forman un oligómero compuesto tanto de nucleótidos conjugados con digoxigenina o sin ella en una secuencia aleatoria.

Los fragmentos de ADN marcados con nucleótidos con digoxigenina se visualizan con un anticuerpo anti-digoxigenina conjugado con peroxidasa, la cual reacciona con sustratos cromogénicos y de esta manera pueden observarse tinciones positivas.

Los cortes histológicos fueron contrastados también con la tinción hematoxilina de Mayer. Los controles negativos se incluyeron en cada serie de secciones ensayadas.

\subsubsection{Ensayos electrofisiológicos}

Para estos ensayos se utilizó el músculo sartorio de la rana Leptodactylus ocellatus (fig. 3.4). Con el fin de controlar la tensión en una contracción aislada del músculo, el tendón pélvico del sartorio fue sujetado a la parte baja de un acrílico vertical, mientras que el tendón distal se conectó a un transductor de fuerza UFI 1030 (Morro Bay, CA) cuya actividad fue registrada con una grabadora de TA240 EasyGraf (Gould Inc., Valley View, Ohio).

El músculo fue estimulado con pulsos de 0,5 milisegundos emitidos a través de electrodos de platino colocados en el portafiltro y conectados a un estimulador Grass S48 (West Warwick, Rhode Island).

Se sumergió la preparación en solución Ringer fisiológica (115 mM NaCl; 2,5 $\mathrm{mM} \mathrm{KCl} ; 1,8 \mathrm{mM} \mathrm{CaCl} 2 ; 2,15 \mathrm{mM} \mathrm{Na} 2 \mathrm{HPO}_{4}$ y $\left.0,85 \mathrm{mM} \mathrm{NaH}_{2} \mathrm{PO}_{4}, \mathrm{pH} 7,18\right)$.

El músculo fue expuesto tanto a la fracción soluble de huevo en solución Ringer (300 $\mu \mathrm{g} / \mathrm{ml})$ como a las fracciones proteicas del citosol: PV2 (30 $\mu \mathrm{g} / \mathrm{ml})$, OR $(100 \mu \mathrm{g} / \mathrm{ml})$ y PV3 $(30 \mu \mathrm{g} / \mathrm{ml})$ todas diluidas en solución Ringer fisiológica, registrándose el efecto sobre la contracción. 
Figura 3.4: Rana Leptodacty/us ocellatus, sus miembros posteriores en solución Ringer y electrodos
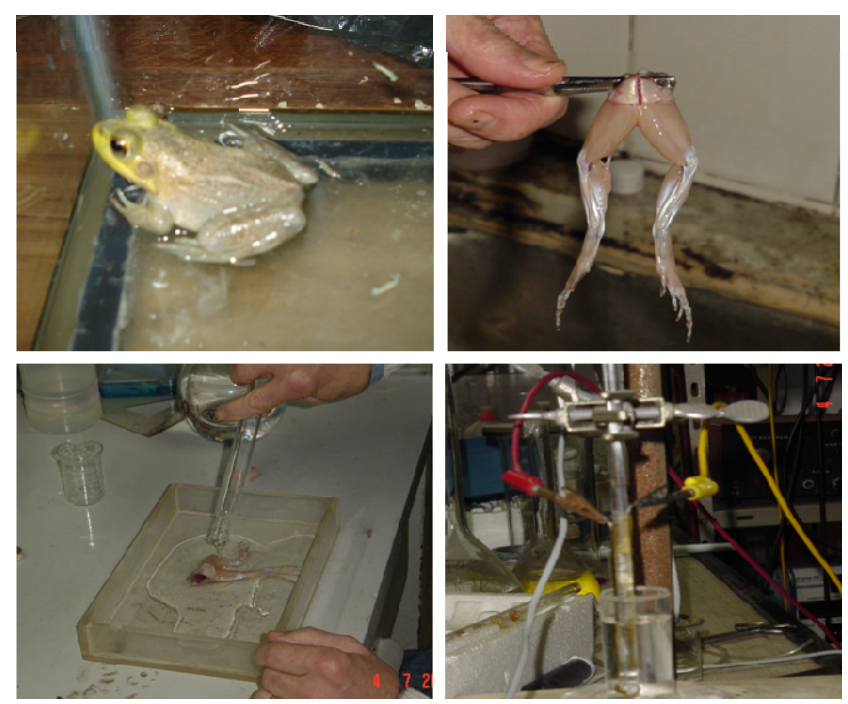

\subsection{Digestión gastrointestinal simulada}

Se realizó una digestión gastrointestinal simulada in vitro de la perivitelina PV2 de acuerdo al método descripto previamente por Moreno et al. (2005) con algunas modificaciones. Como control positivo de la actividad enzimática se incubó en iguales condiciones BSA (Sigma) tanto en la digestión gástrica como duodenal. La fase gástrica se realizó incubando $10 \mu \mathrm{g}$ de PV2 dializada con 1,82 UE de pepsina gástrica porcina (Sigma) en una solución de $\mathrm{NaCl} 150 \mathrm{mM}$ a pH 2,5 ajustada con $\mathrm{HCl}$ que llamaremos fluido gástrico simulado (FGS), la proporción enzima: sustrato fue $1: 20(\mathrm{p} / \mathrm{p})$ y la incubación se realizó a $37^{\circ} \mathrm{C}$ durante $2 \mathrm{~h}$. La reacción se detuvo agregando buffer muestra de electroforesis SDS.

A continuación se realizó sobre alícuotas de la perivitelina previamente digerida con pepsina, una digestión controlada con tripsina pancreática bovina (Sigma) en buffer Tris/ $\mathrm{HCl}$ pH 8,0. Esta proteasa hidroliza preferentemente las uniones peptídicas en el extremo carboxílico que contenga residuos arginina (Arg) y lisina (Lys). Se utilizó en una relación proteína: tripsina de 1:400 (p/p) incubándose a $37^{\circ} \mathrm{C}$ durante $2 \mathrm{~h}$.

Los fragmentos producto de la proteólisis se visualizaron en ambos casos mediante geles SDS-PAGGE 4-20\%. 


\subsection{Efecto de la alimentación y esfuerzo reproductivo en la calidad de huevos}

3.9.1 Cría de P. canaliculata en laboratorio. Condiciones de alimentación

Se emplearon individuos adultos de P. canaliculata (30 hembras y 30 machos) que fueron recolectados en noviembre de 2009 en el Arroyo Guaminí (3710'37.66"S, 62²5'58.52"O, provincia de Buenos Aires).

Cada pareja se mantuvo por una semana en un acuario con lechuga ad libitum, con el objetivo de registrar al menos una puesta de cada hembra o en su defecto una cópula; asegurándonos, de esta manera, de que la hembra estaba madura, con capacidad de oviponer o bien que la cantidad de esperma era suficiente.

Luego del registro de la oviposición o cópula, el macho se retiró del acuario y se colocó en un acuario colectivo con los restantes machos apartados de las hembras. Pasada esa semana inicial, se seleccionaron 24 hembras para la realización del ensayo, tomando como criterio de selección aquellas que hubieran ovipuesto al menos una vez en esa semana de aclimatación.

Una vez por mes se colocó al macho con la hembra en el acuario durante tres días para asegurar la provisión de esperma fresco y viable.

El ensayo se llevó a cabo durante todo el período reproductivo, desde fines de noviembre de 2009 hasta fines de abril de 2010, en acuarios individuales de 31 de capacidad con agua y $\mathrm{CaCO}_{3}$ a saturación, con fotoperíodo y temperatura no controlados. Cada hembra fue alimentada con una ración completa $(C)$ o restringida (M) de lechuga (100\% $050 \%$ de la ingesta diaria, respectivamente)(Tamburi \& Martín, 2009a) suministradas en dos medias raciones, los lunes y viernes. La temperatura y la humedad ambiental fueron registradas con un dispositivo de registro Hobo®.

Las puestas para análisis bioquímico fueron retiradas inmediatamente luego de ser detectadas y congeladas a $-20^{\circ} \mathrm{C}$ hasta su posterior análisis.

El experimento concluyó al transcurrir dos semanas sin nuevas oviposiciones. 
3.9.2 Medidas de reflectancia de huevos

La espectroscopía de reflectancia mide la radiación reflejada por una muestra. Las mediciones de reflexión difusa se emplearon para determinar el color de la muestra.

Se midió la reflectancia de puestas de huevos de $P$. canaliculata, utilizando un espectrómetro USB4000-UV-VIS (Ocean Optics, USA) con fuente de luz blanca y fibras ópticas, adquiriendo y analizando los espectros con el software SpectraSuite (Ocean Optics). Se tomaron al menos tres medidas de reflectancia por cada puesta, que fueron promediadas para tener un valor estadísticamente más representativo. El equipo se calibró previamente tomando como patrón de referencia un disco de teflón blanco, asumiendo que este posee el $100 \%$ de reflectancia.

\subsubsection{Determinación de galactógeno}

Para cuantificar el galactógeno de las puestas de huevo (la principal fuente de energía durante el desarrollo embrionario), se realizó su extracción siguiendo el protocolo de Van Handel (1965). Para ello, se hirvió durante $20 \mathrm{~min}$ una solución que contenía 0,5 ml de fracción soluble de huevos y 0,5 ml de $\mathrm{KOH} 66 \%$. Luego se añadieron $50 \mu$ de $\mathrm{SO}_{4} \mathrm{Na}_{2}$ y $1,25 \mathrm{ml}$ de etanol $96^{\circ}$, se calentó durante 5 min y se centrifugó a $2000 \mathrm{rpm} 10$ min. Por último se descartó el sobrenadante y se secó el pellet, que fue resuspendido en $0,5 \mathrm{ml}$ de agua.

Una vez purificado el galactógeno, se determinó colorimétricamente su contenido total por el método Fenol-Sulfúrico (Manzi \& Esko, 1995). Se empleó para la curva de calibración glucógeno (Sigma) como estándar. Las muestras se incubaron en una solución de fenol al $5 \%$ en $\mathrm{H}_{2} \mathrm{SO}_{4}$ concentrado durante 30 min a $37^{\circ} \mathrm{C}$ y el desarrollo de color se detectó midiendo absorbancia a $485 \mathrm{~nm}$. 
CAPITULO 4 


\section{CAPITULO 4: Estructura}

\subsection{Introducción}

Los huevos de $P$. canaliculata poseen tres perivitelinas mayoritarias, $O R$, PV2 y PV3, todas ellas proteínas oligoméricas que están emergiendo como un eficiente y complejo sistema de protección y defensa de los embriones en desarrollo.

En particular, PV2 es una glicolipoproteína de 400 kDa (Garín et al., 1996) y está compuesta por dos subunidades de 67 kDa (número de acceso en Swiss-Prot POC8G6) y $31 \mathrm{kDa}$ (POC8G7). Como componente del fluido perivitelino del huevo, lleva a cabo funciones estructurales y nutritivas al ser incorporada y degradada por el embrión durante el desarrollo (Heras et al., 1998). Recientemente hemos descubierto que además cumple una función protectora dada su naturaleza neurotóxica (ver capítulo 6).

Actualmente, la información estructural que se conoce sobre proteínas de huevo de moluscos gasterópodos está referida principalmente a su estructura primaria y a las funciones que cumplen. Se han descripto especialmente funciones antibacterianas, antifúngicas y citotóxicas (Iijima et al., 1995, Kisugi et al., 1989, Melo et al., 2000, Mukai et al., 2004, Yamazaki, 1993, Yamazaki et al., 1985). Por el contrario, el conocimiento de la estructura tridimensional de perivitelinas de invertebrados se limita a la OR de P. canaliculata (Dreon et al., 2007, 2008, Ituarte et al., 2008).

En este capítulo se presentan los resultados que permiten inferir el tamaño, forma y estructura en solución de la PV2, obtenidos por medio de dispersión de rayos $X$ a bajo ángulo (SAXS), espectroscopía de absorción y fluorescencia, dicroísmo circular (CD) y microscopía electrónica de transmisión (TEM). 


\subsection{Caracterización estructural}

Con el fin de completar la caracterización básica de PV2 se determinó el pI de la forma nativa y sus subunidades mediante electroforesis bidimensional tanto en condiciones nativas como disociantes.

El perfil electroforético obtenido para PV2 nativa mostró un único spot con un $\mathrm{pI} \sim 6,2$ (fig. 4.1.A). En el caso de la subunidad mayor de $67 \mathrm{kDa}$ el pI fue 5,2 (círculo rojo fig. 4.1.B), mientras que para la subunidad menor pudieron observarse varias isoformas todas con el mismo peso molecular (PM) de $31 \mathrm{kDa}$, pero con diferentes $\mathrm{pI}$ en un rango entre 4,7 a 9 (círculos azules, fig. 4.1.B).

Figura 4.1: Electroforesis bidimensional de PV2. A: PAGE, B: SDS-PAGE. En sentido horizontal las proteínas están separadas según su pI; en sentido vertical según PM.

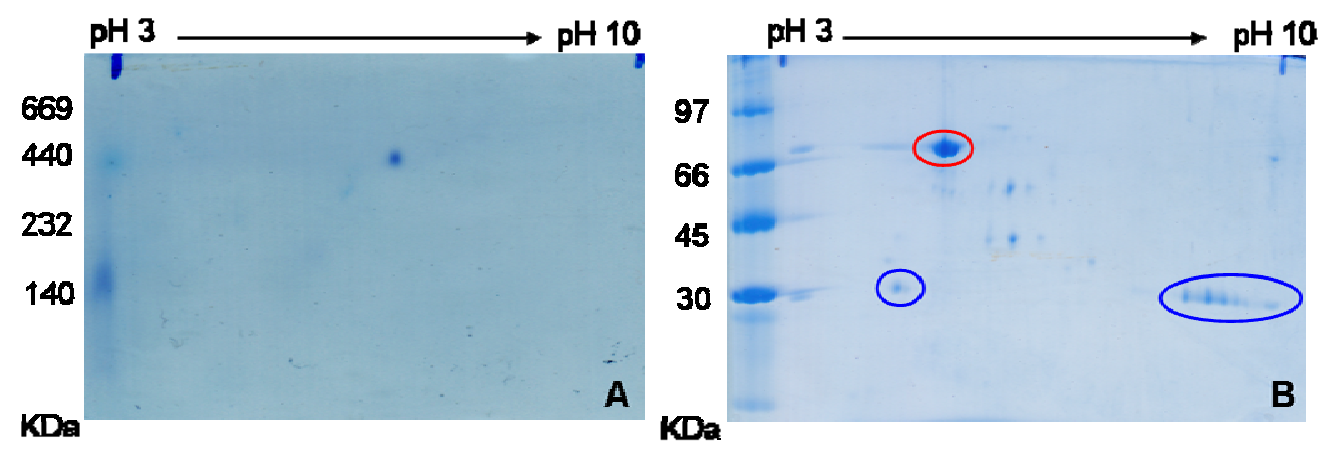

Por otra parte se determinó el número de residuos de cisteínas presentes en la PV2 expuestos a diferentes concentraciones de urea, midiendo la emisión de fluorescencia de la sonda monobromobimano $(\mathrm{mBr} B)$. La emisión de $\mathrm{mBr} B$ mostró un claro comportamiento cinético con $t_{50}=35 \pm 1 \mathrm{~min}$. Se realizó un experimento equivalente BSA que presenta una cantidad conocida de 35 residuos de cisteínas, en la cual se observó una cinética similar con $t_{50}=37 \pm 1$ min. Los valores de $t_{50}$ obtenidos para PV2, en especial en comparación con los obtenidos para BSA, sugieren que los residuos de cisteína presentes se encuentran enterrados en el interior de la estructura posiblemente formando, en muchos casos, uniones S-S. 
Comparando el valor de saturación de fluorescencia entre BSA y PV2, pudo estimarse un valor aproximado de 32 residuos de cisteínas para PV2 (fig. 4.2.A).

Para evaluar si las cisteínas se encontraban formando puentes disulfuro (S-S) en la proteína, se realizó un SDS-PAGGE 4-20\% p/v en presencia y en ausencia del agente reductor $\beta$-ME (fig. 4.2.B). Se pudo observar la presencia de una única banda de $98 \mathrm{kDa}$ en ausencia de $\beta-M E$ (fig. 4.2.B calle 3), que demostraría la existencia de puentes S-S intercatenarios entre las subunidades de PV2.

Así, de manera conclusiva, podemos afirmar que PV2 presenta 32 residuos de cisteína, algunos de los cuales forman puentes S-S intercatenarios entre las subunidades de 31 y 67 kDa que ayudan a estabilizar la estructura cuaternaria de la proteína en condiciones nativas.

Figura 4.2: A: Determinación de cisteínas totales en PV2; B: SDS-PAGGE, 1 : Estándar de bajo peso molecular; 2: PV2 en presencia de $\beta-M E ; 3: P V 2 \sin \beta-M E$.
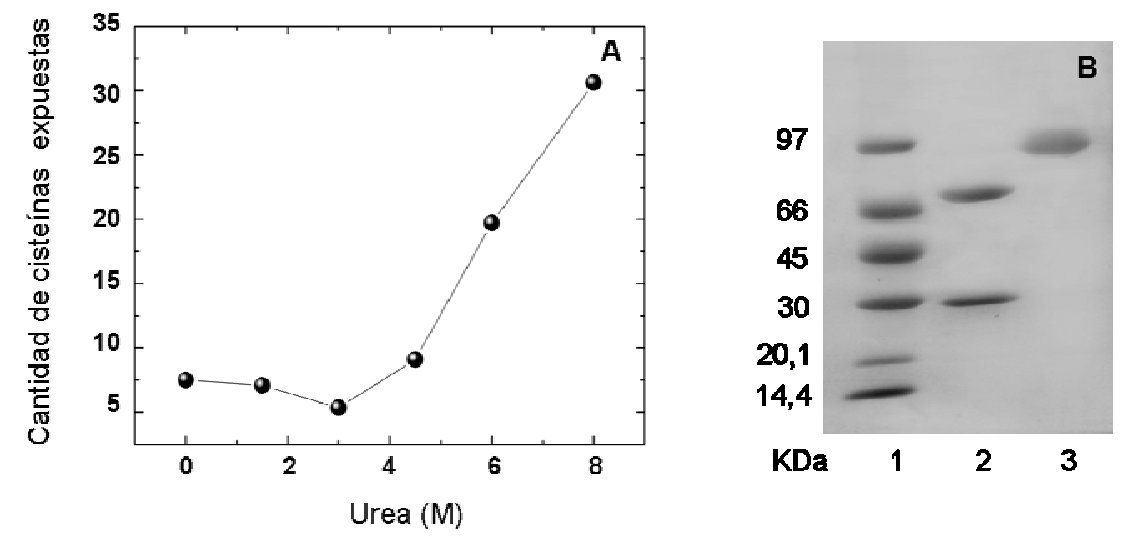

\subsection{Estructura secundaria}

La información sobre la estructura secundaria de una proteína puede estimarse a partir de los espectros de dicroísmo circular obtenidos en la región UV lejano ( $f C D$, entre 190 y $240 \mathrm{~nm}$ ).

En la figura 4.3.A puede observarse el espectro $f C D$ obtenido para la PV2 nativa donde puede identificarse una banda positiva con un máximo cercano a 190 
nm y una banda negativa con dos mínimos distribuidos entre 225 y $205 \mathrm{~nm}$ aproximadamente. El aspecto general del espectro es característico de una proteína con un plegamiento de tipo $\alpha+\beta$.

En base a los datos del espectro previamente descripto, se aplicaron los algoritmos K2d (Andrade et al., 1993) y Contin (Provencher \& Glockner, 1981) con el fin de estimar el porcentaje de ambas estructuras presentes en PV2 nativa. Ambos algoritmos dieron resultados similares, estimando un promedio de $21 \%$ de estructura $a, 25 \%$ de estructura $\beta$ y $54 \%$ ovillo aleatorio o no estructurado a una temperatura de $20^{\circ} \mathrm{C}$ (fig. 4.3.B).

Figura 4.3: Estructura secundaria de PV2. A: Espectro fCD de PV2; B Tabla del contenido de estructura secundaria de PV2 nativa.

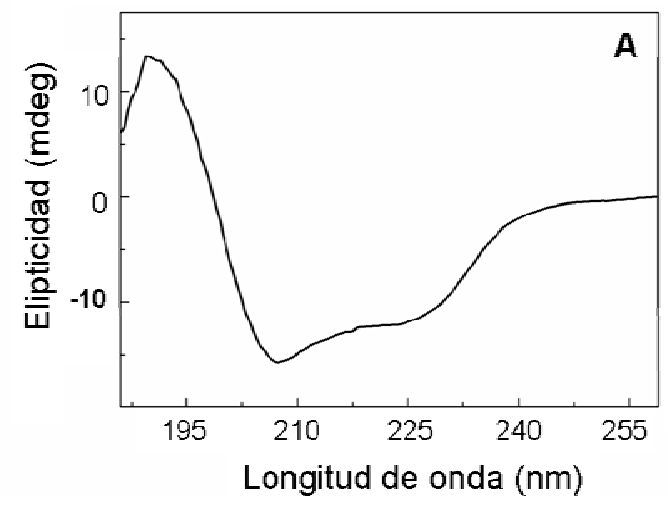

B
\begin{tabular}{|c|c|c|c|c|c|c|}
\hline $\begin{array}{c}\mathbf{T} \\
{ }^{\circ} \mathbf{C}\end{array}$ & \multicolumn{2}{|c|}{$\begin{array}{c}\text { Hélice } \alpha \\
(\%)\end{array}$} & \multicolumn{2}{c|}{$\begin{array}{c}\text { Lámina } \beta \\
(\%)\end{array}$} & \multicolumn{2}{|c|}{$\begin{array}{c}\text { Ovillo } \\
\text { aleatorio }\end{array}$} \\
\cline { 2 - 7 } & $\mathbf{K}^{\star}$ & $\mathbf{C}^{*}$ & $\mathbf{K}$ & $\mathbf{C}$ & $\mathbf{K}$ & $\mathbf{C}$ \\
\hline $\mathbf{2 0}$ & 21 & 22 & 22 & 28 & 56 & 49 \\
\hline
\end{tabular}

$\mathrm{K}^{\star}$ : Algoritmo k2D $\quad \mathrm{C}^{\star}$ :Algoritmo Contin

\subsection{Estructura terciaria y cuaternaria}

La caracterización estructural de PV2 se completó estudiando la conformación que adopta en el espacio, para lo cual se utilizaron diversas técnicas biofísicas.

Se realizó el espectro de absorción UV de PV2 nativa junto con su espectro de cuarta derivada (fig. 4.4.A). El espectro de cuarta derivada estuvo dominado claramente por fuertes señales provenientes de residuos de $\operatorname{Trp}(290 \mathrm{~nm})$ y Phe $(260 \mathrm{~nm})$, respectivamente. 
Se realizaron también medidas de la emisión de fluorescencia de Trp que brindaron información acerca del entorno (promedio) en el que se encuentran dichos aminoácidos. El espectro obtenido para PV2 nativa mostró un máximo de emisión a $338 \mathrm{~nm}$ (fig. 4.4.B), indicando que, en promedio, los anillos indólicos presentes en los Trp se encuentran en un entorno hidrofóbico (Lakowicz, 1999).

Los espectros de dicroísmo circular en la región UV-cercano (nCD, entre 260 y $320 \mathrm{~nm}$ ) mostraron fuertes señales centradas en 282 y $291 \mathrm{~nm}$ que corresponden a residuos de aminoácidos Tyr y Trp respectivamente que se encuentran ocluidos en el núcleo de la proteína.

Figura 4.4: Características estructurales de PV2. A: Espectro de absorción de PV2 (línea continua) y espectro de cuarta derivada (línea discontinua); B: Medida de fluorescencia intrínseca de PV2; $C$ : espectro $\mathrm{NCD}$ de PV2

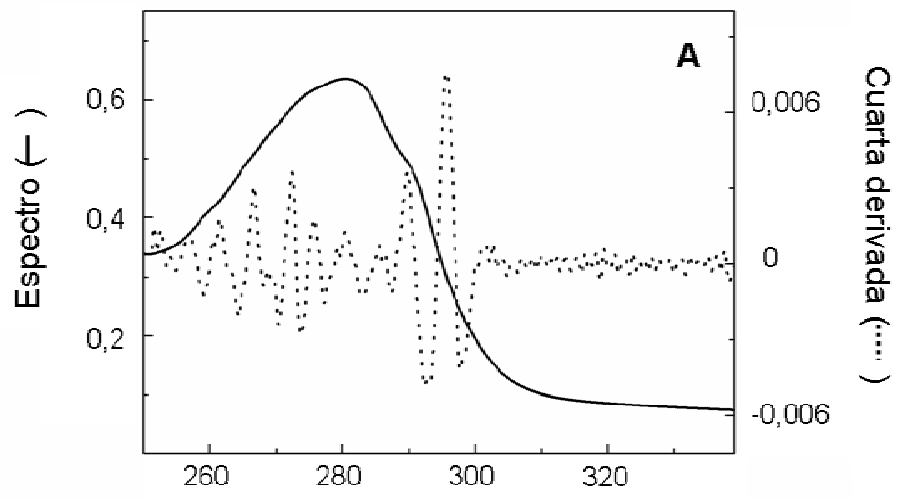

Longitud de onda (nm)
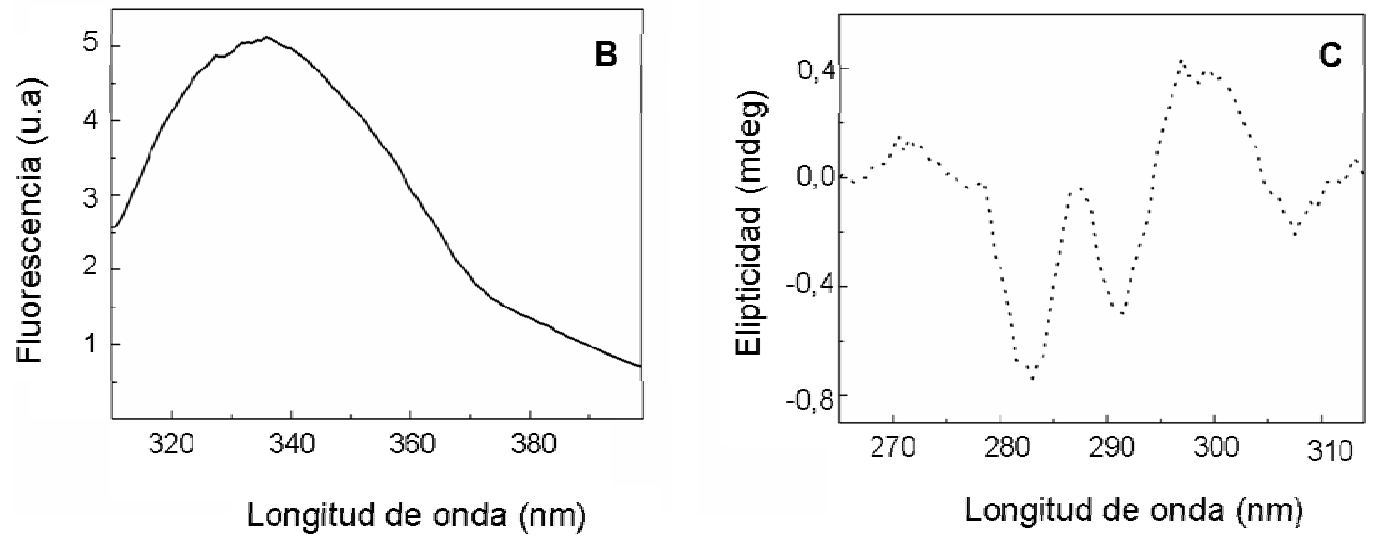
Con el fin de estudiar el grado de exposición de los residuos de Trp de la proteína a su entorno, se realizaron experimentos de quenching con acrilamida de la señal de fluorescencia del Trp. A medida que se incrementaron las cantidades de acrilamida, pudo observarse una disminución de la intensidad de los espectros de emisión pero sin corrimiento en su longitud de onda (fig. 4.5.A), como se esperaría si estuviéramos en presencia de residuos Trp con diferente exposición a solventes (Lakowicz, 1999).

La figura 4.5.B muestra la diferencia de intensidad de fluorescencia en ausencia y en presencia del quencher registrada a $339 \mathrm{~nm}$. Los puntos experimentales manifestaron una clara curvatura hacia arriba que no puede explicarse con el modelo simple de Stern-Volmer (Lakowicz, 1999). Así, el grado de exposición al solvente de los anillos indólicos de Trp se cuantificó empleando el modelo de quenching de "esfera de acción" (Frank \& Vavilov, 1931, Lakowicz, 1999), una versión modificada del modelo de Stern-Volmer. Este modelo postula que dentro de un volumen crítico alrededor del fluoróforo, todos los quenchers tendrán una probabilidad de quenching del 100 \% lo que se manifiesta en un rápido aumento de la eficiencia de apagado (observado como una curvatura positiva en la curva) a medida que aumenta la concentración de quencher. La forma matemática de la ecuación resultante se muestra en la ecuación 1.

\section{Ecuación 1:}

$$
\begin{aligned}
& F_{0} / F=\left(1+K_{S V}(Q)\right) e^{(Q) V} \\
& K_{S V}=T_{0} K_{q}
\end{aligned}
$$

Donde $F$ y $F_{0}$ corresponden a la intensidad de fluorescencia para una determinada concentración de quencher $(Q)$ y para $(Q)=0$, respectivamente, $K_{S V}$ es la constante de quenching de Stern-Volmer, $V$ es el volumen excluido (dentro del cual la eficiencia de quenching es $100 \%$ ) para el par fluoróforo-quencher, to es la vida media del fluoróforo en su estado excitado en ausencia de quencher y $k_{q}$ es la 
constante bimolecular aparente de quenching (Lakowicz, 1999, Frank \& Vavilov, 1931).

Como era de esperar, para concentraciones altas de quencher, aumenta la probabilidad de encontrar una molécula del mismo dentro de la esfera crítica y, por lo tanto, la ecuación de Stern-Volmer se aleja del comportamiento lineal (Lakowicz, 1999) (fig. 4.5.B).

Usando la ecuación 1 se obtuvieron valores de $K_{s V}=6,0 \pm 0,4 M^{-1}$ y $V=748 \pm 133 \AA^{3}$ (línea continua en la fig. 4.5.B). Asumiendo una forma esférica para $V$, se obtiene un radio $r=5,6 \pm 0,3 \AA$ para la "esfera de acción". La suma de los radios moleculares para el Trp y la acrilamida fue calculada utilizando el algoritmo implementado en http://www.molinspiration.com/cgi-bin/properties obteniendo un valor de rcalc $=6,3 \AA$ en razonable concordancia con el resultado obtenido para el radio de la esfera a partir de los experimentos de quenching.

Utilizando la fórmula $K_{S V}=T_{0} k_{q}$ de la ecuación 1 y, suponiendo un tiempo de vida $T_{0}=3$ ns para el Trp en estado excitado, se obtuvo un valor para la constante bimolecular aparente de quenching $\mathrm{k}_{q}=(2,0 \pm 0,1) \times 10^{9} \mathrm{M}^{-1} \mathrm{~s}^{-1}$.

Figura 4.5: Cambios en el espectros de fluorescencia de Trp de PV2 por efecto del quenching por acrilamida. A: Espectros de fluorescencia de Trp de PV2 en función de la cantidad de archilamida (O a 1 M); B: Gráfico de Stern-Volmer obtenido a partir de la intensidad de fluorescencia a $339 \mathrm{~nm}$ (máximo espectral). La línea continua corresponde al ajuste de la ecuación 1 a los datos experimentales.
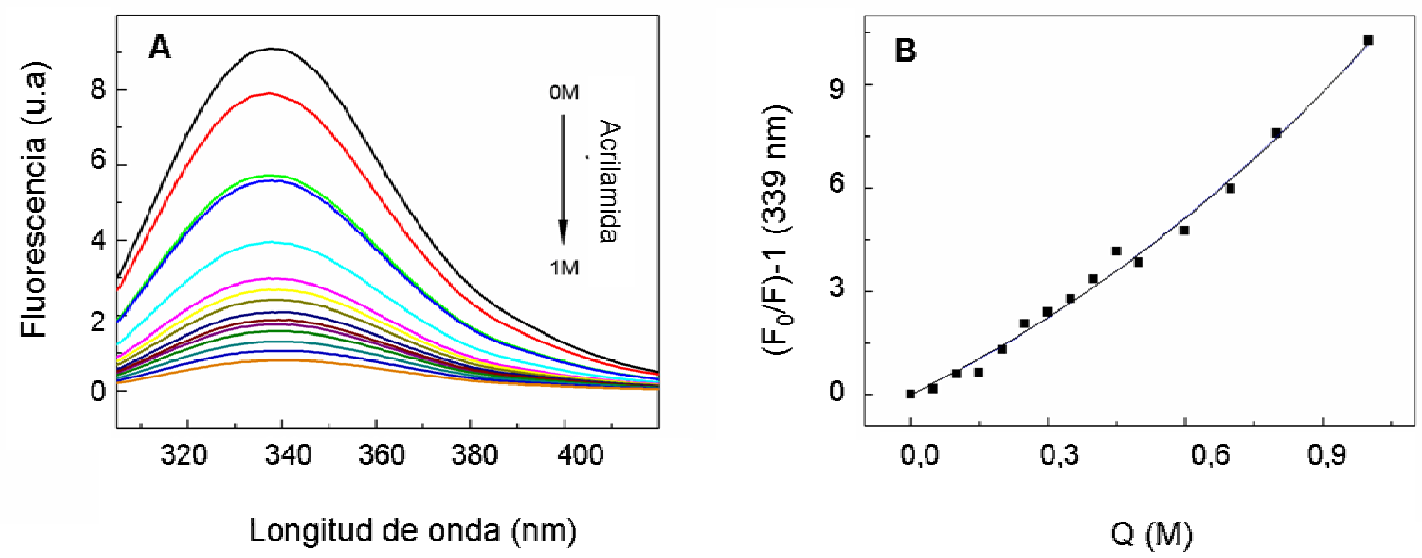
A pesar de que PV2 es una proteína de alto peso molecular, con previsiblemente un alto número de Trp, nuestros experimentos de quenching sugieren la existencia de una única clase de residuos de Trp en el sentido que su "respuesta" ante la presencia de la acrilamida no refleja diferentes grados de exposición.

En el análisis de este tipo de resultados, Eftink (1991) demostró una correlación empírica entre la posición de emisión máxima del espectro de fluorescencia ( $\wedge$ max) y el valor de $k_{q}$ para el quenching de la emisión en proteínas con Trp único. Teniendo en cuenta dicha correlación es posible concluir que los residuos de Trp en PV2 se encuentran ocluidos, pero no totalmente enterrados, en la estructura terciaria de PV2.

El tamaño y la forma global de la estructura cuaternaria de PV2 fueron estudiados mediante experimentos SAXS (fig. 4.6.A). Esta técnica permite obtener información estructural de la proteína en solución y a concentraciones cercanas a los valores aceptados como "fisiológicos". A partir del ajuste lineal en la región de bajo $Q$ o región de Guinier $\left(\ln (I(Q))\right.$, se calculó un $R_{G}$ para la proteína nativa de $44 \pm 1 \AA$ como se muestra en el recuadro de la figura 4.6.A. Este valor de $R_{G}$ coincide remarcablemente bien con el esperado para una proteína compacta de peso molecular aparente de $400 \mathrm{kDa}$.

El gráfico de Kratky $\left(I(Q)^{\star} Q^{2}\right.$ vs $\left.Q\right)$, utilizado para inferir la globularidad de la proteína, mostró una forma de campana, que es típica para proteínas globulares (fig. 4.6.B).

La distribución de pares de distancias $P(R)$, a partir de los datos obtenidos por SAXS, pudo calcularse utilizando el método de regularización de transformada de Fourier mediante el uso del programa GNOM 4.5 (Svergun, 1992), que mostró un máximo bien definido de $44 \AA$ con una Dmax de $130 \AA$ para PV2 nativa. Estos valores son compatibles con una partícula anisométrica (fig. 4.6.C). 
Figura 4.6: Estructura de PV2 obtenida mediante SAXS. A: Datos SAXS. Recuadro: región Guinier en las variables linealizadas; $B: G r a ́ f i c o ~ d e ~ K r a t k y ~\left(I ~(Q)^{\star} Q^{2}\right.$ vs. $\left.Q\right)$ de los datos representados en el panel $A$; $C$ : Distribución de pares de distancia a partir de datos del panel $A$, obtenidos mediante el programa GNOM 4.5. Línea de puntos: Intensidad de dispersión de los datos experimentales para PV2; línea continua: modelo teórico del átomo ficticio.
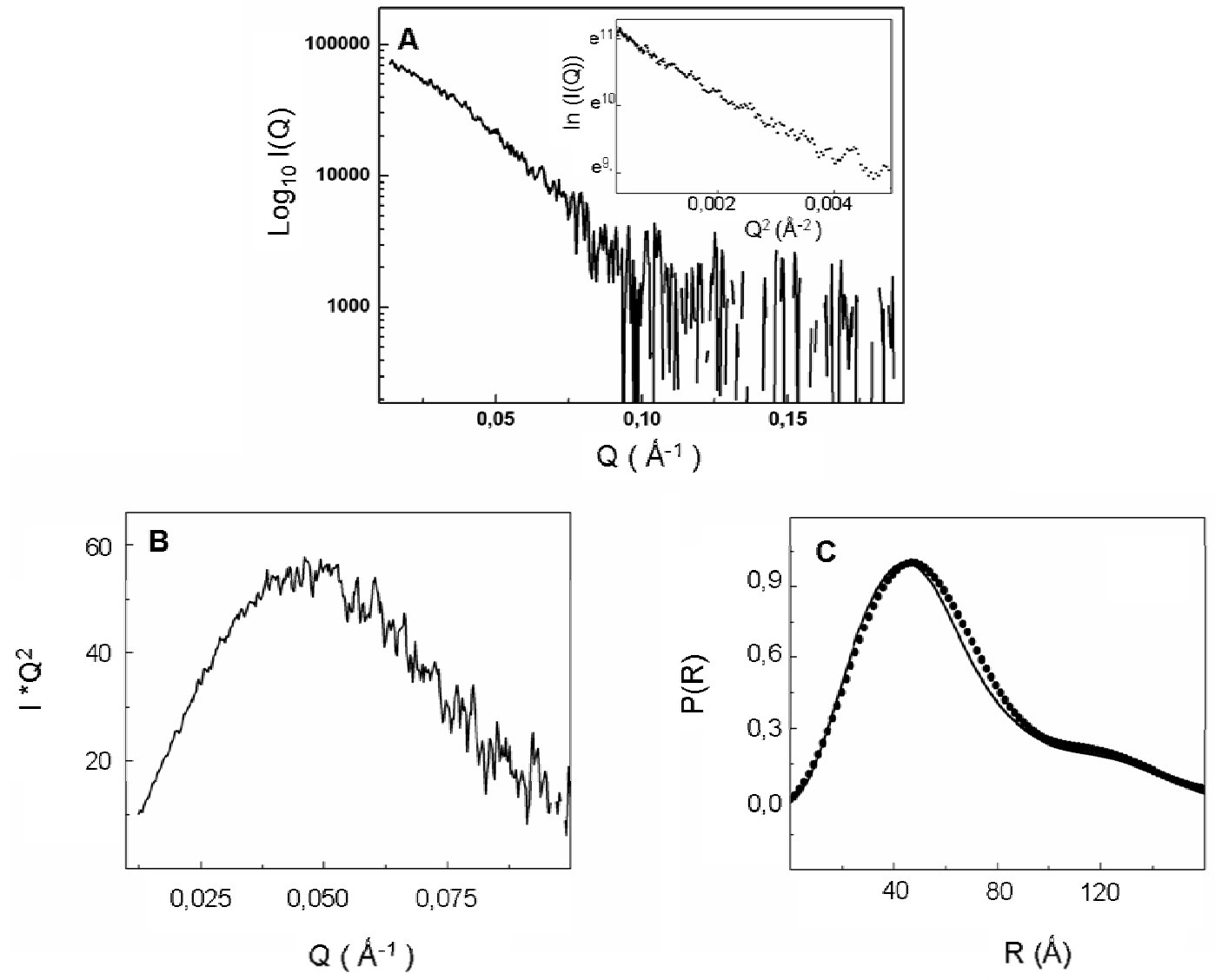

Con estos datos se pudo obtener un modelo de baja resolución para PV2 nativa, utilizando la técnica de annealing simulado, implementada en el programa DAMMIN (Svergun, 1999). El modelo final se logró promediando 16 modelos independientes, calculados aplicando los algoritmos implementados en el paquete de programas DAMAVER (Volkov \& Svergun, 2003) (fig. 4.7). Se debe remarcar que la obtención de este modelo de baja resolución no requiere la cristalización de la proteína ya que emplea los datos SAXS obtenidos de experimentos en solución. 
Figura 4.7: Modelo tridimensional de baja resolución de la forma de PV2 obtenido a partir de los datos de SAXS, aplicando DAMMIN. A: vista; B: giro de $90^{\circ}$ alrededor del eje y; C: giro de $90^{\circ}$ alrededor del eje $z$.

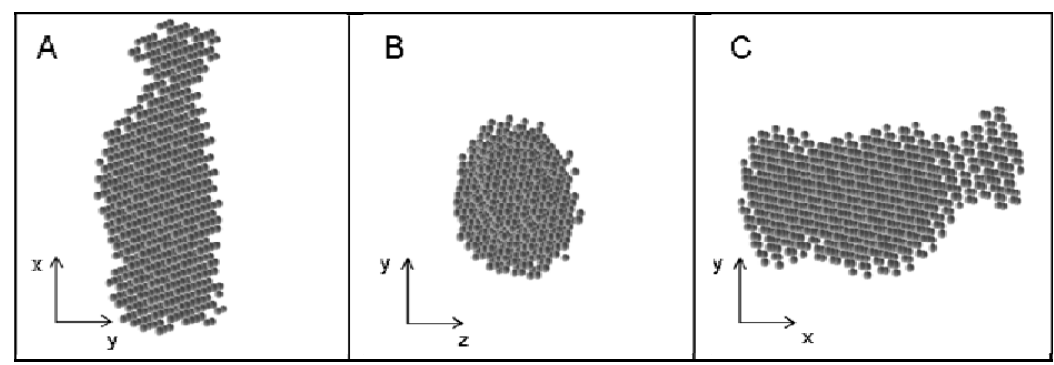

Finalmente se realizaron medidas de MET de PV2 para intentar corroborar los tamaños registrados con los algoritmos utilizados.

La imagen obtenida (fig. 4.8.A) presentaba partículas cuyos tamaños fueron analizados con el programa ImageJ. La distribución de tamaños se muestra como un histograma (fig. 4.8.B) que tiene un máximo de alrededor de $137 \AA$.

Figura 4.8: A: Imagen de microscopía electrónica de PV2; B: Distribución de tamaño de las moléculas de PV2 obtenidos por análisis de MET.
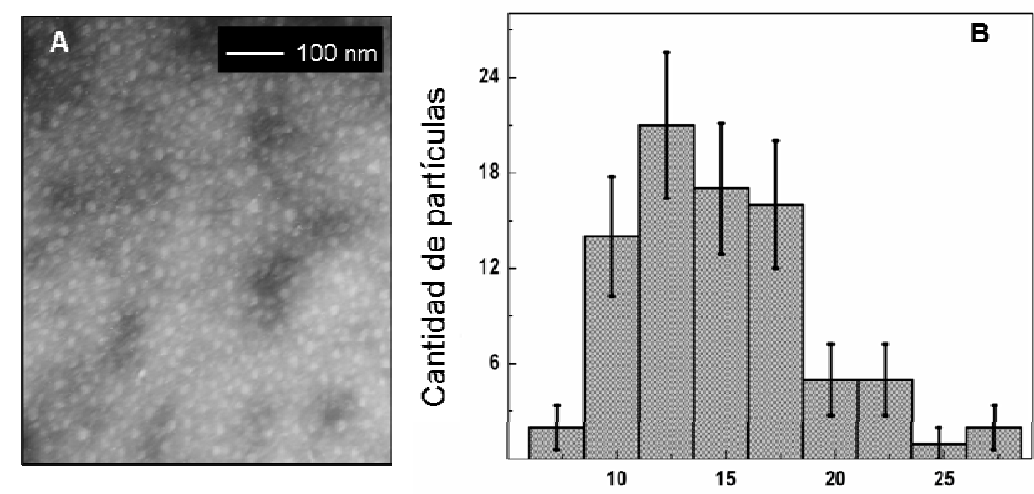

Diámetro de partículas $(\mathrm{nm})$

Se pudo observar que el tamaño inferido por el modelo ab initio del átomo ficticio implementado en el programa DAMMIN, obtenido con los datos experimentales de intensidad de dispersión (fig. 4.7), es coincidente con el tamaño sugerido por los datos de microscopía electrónica. 


\subsection{Estructura primaria de la subunidad menor de PV2}

Con el fin de obtener la secuencia total o parcial de las subunidades de PV2, se purificó ARN total a partir de la glándula del albumen de P. canaliculata.

Primeramente, se recolectaron hembras que denominamos "reproductivas" y "no reproductivas" según estuvieran o no copulando en el momento de la recolección. De esta manera, haciendo un pool de ambos tipos de glándulas, se obtuvo un conjunto heterogéneo, en diferentes estadios, minimizando así posibles diferencias debidas a esta variable. La figura 4.9.A muestra la diferencia de color de las glándulas entre estos dos grupos.

EI ARN se extrajo mediante dos métodos (ver sección 3.5.2). La integridad de ARN se verificó mediante electroforesis en gel desnaturalizante (figura 4.9.B), la concentración se determinó midiendo $A_{260}$ y la pureza se estimó calculando la relación $A_{260} / A_{280}$ (tabla 4.1). En base a la pureza del $A R N$ obtenido, decidimos utilizar el ARN extraído empleando el método del kit comercial.

Figura 4.9: Obtención de ARN total de glándula del albumen. A: Glándulas del albumen de hembras en diferente estado reproductivo: "reproductivas" fuertemente coloreadas (flecha amarilla) y "no reproductivas" de color amarronado (flecha verde). B: Gel desnaturalizante de ARN, calle 1: ARN de glándula, calle 2: estándar de peso molecular.
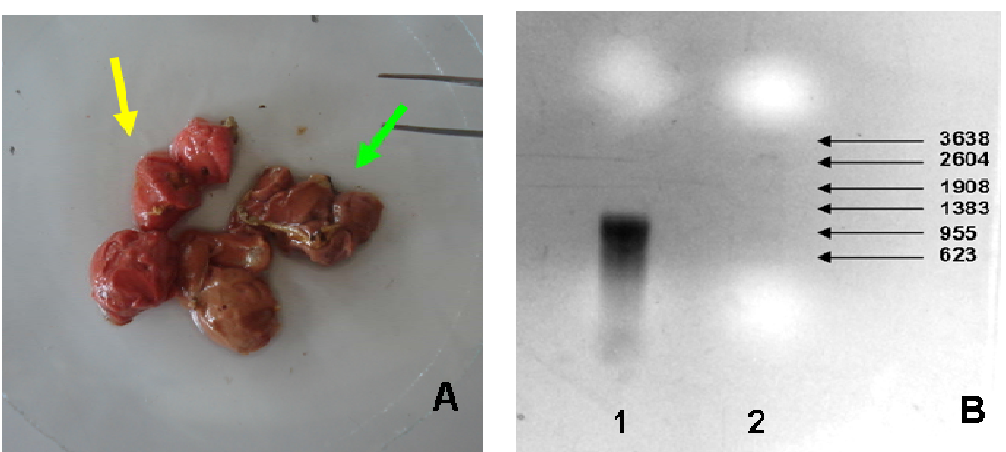
Tabla 4.1: Comparación de la pureza y cantidad de ARN obtenido por los dos métodos ensayados.

\begin{tabular}{|c|c|c|}
\hline Método de extracción & Kit & Trizol \\
\hline$A_{260}$ & 0,8 & 1,004 \\
\hline$A_{280}$ & 0,389 & 0,605 \\
\hline Concentración & $320 \mu \mathrm{g} / \mathrm{ml}$ & $402 \mu \mathrm{g} / \mathrm{ml}$ \\
\hline Relación $A_{260} / A_{280}$ & 2,05 & 1,66 \\
\hline
\end{tabular}

EI ADNc obtenido por RT a partir del ARN total se empleó para amplificar las secuencias de PV2 empleando los primers degenerados, descriptos en el capítulo de metodología (sección 3.5.5, tabla 1.2).

Los fragmentos obtenidos con los diferentes pares de primers se analizaron en un gel de agarosa $1 \%$ (fig. 4.10.A). Los tamaños de los mismos fueron los siguientes: un único fragmento de 900-1000 pares de bases (pb) con el primer $\mathrm{N}_{\text {terminal }}(\mathrm{Nt})$ (rojo, número 1); dos fragmentos de 250 y 150 pb con el primer tríptico 1 (verde, número 2 y 3 respectivamente) y tres fragmentos de aproximadamente 500, 400 y 300 pb con el primer tríptico 2 (azul, número 4, 5 y 6 respectivamente).

Figura 4.10: A: Electroforesis en gel de agarosa $1 \%$ de los productos de PCR con primers degenerados; B: Tamaño de los insertos clonados en bacterias a partir de las bandas 1 a 6 del gel $A$ mediante electroforesis en gel de agarosa. Los plásmidos fueron previamente linealizados por tratamiento con EcoRI.
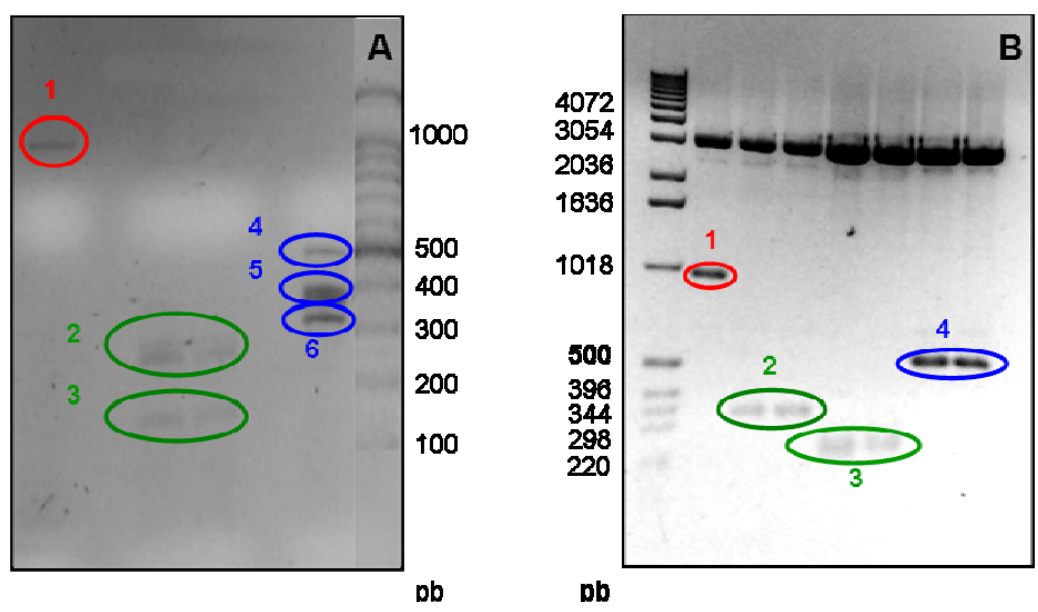
Cada una de esas seis bandas fue extraída y su ADN purificado fue clonado en el vector PGEM-T easy. Los plásmidos resultantes de esta ligazón se utilizaron para transformar bacterias competentes. Luego se extrajeron los plásmidos de las colonias con inserto y se digirieron con la enzima EcoRI para controlar la presencia del inserto del tamaño buscado en esos plásmidos (fig. 4.10.B) (no se muestran las ligazones donde no pudo encontrarse el inserto).

Finalmente, el ADN aislado se secuenció y las secuencias obtenidas fueron alineadas entre sí con el programa LALIGN versión 2.0 (Huang \& Miller, 1991). No se encontraron secuencias internas con los primers degenerados pero sí una secuencia prácticamente completa de la subunidad menor utilizando el primer Nt. Esa secuencia preliminar fue utilizada como base para construir primers específicos que amplificaran todo el marco de lectura del ADNc, para lo cual se empleó la técnica de RACE y confirmar así la secuencia obtenida (ver sección 3.5.9). Empleando los primers RACE 3'outer y RACE 5' outer obtuvimos una única banda, no así en el caso del primer RACE $5^{\prime}$ inner con el que se registraron dos bandas (fig. 4.11). Todas estas bandas fueron extraídas del gel, clonadas y secuenciadas.

Figura 4.11: Gel de agarosa $2 \%$ de los productos amplificados por RACE 3’ (A) y Race 5' (B)

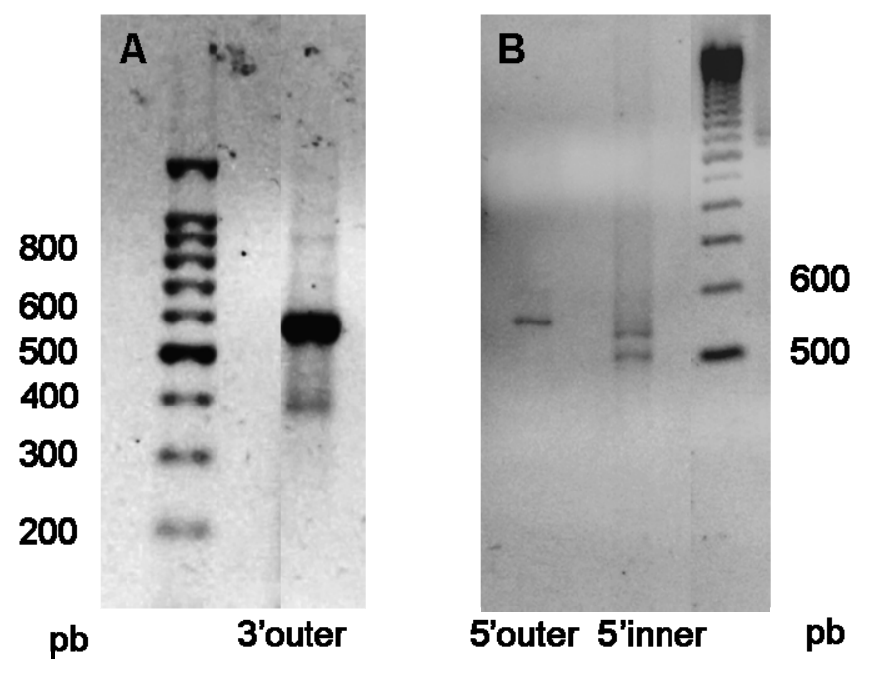


La secuencia de consenso obtenida luego de alinear las diferentes secuencias de los extremos, contenía un marco de lectura abierta (ORF) de 1052 pb correspondiente a 351 residuos de aminoácidos.

Secuencia nucleotídica de subunidad menor de PV2:

5’ ATGGAAAGACACGCTTCTATAGTGGCTTTTCTTCTAGCTGTTCTGGCGCTGACCGAGTCCCAAGCGTT CACCTCCGTGAAACTGCCGAGGGACGAGCACTGGCCCTACAGTTATGTGTCTGTTGGACCGGCTGGCGTG TGGGCTGTCAACCGTCAAAACAAACTCTTCTACCGCACAGGAACCTACGGCGACAACGCCAACATGGGCT CTGGATGGCAGTTTAAGATAGACGGGGTAAATCAGGTGGATGTAGGTAGGGATACAGTAGCCTTTATT AATCCTTCTAAAAGAGCAATGTTTCGTATTGAAGGCATCAATAAAGCCAACCCTCTCGGAGCTTCCCCGT ACAGCTGGGAGTGGTGGACGATGTACATTGGCATGTCTCTGAAACAAGACGTCCGATTCTCTGTTCGTA TCGATACCGACAACAAAGTTCAGACTCTAACATGGCGAACATGCTGGTGGGCTAGCCGCATAACCAACT GGTGTTACGCTGATGGTAGTTATACCGAAACTGTTACCACTGGTGGCTCCGGTACCTGGATCACCAAAAG CCAGTTAAAGTATAAAAGTGGAACCTTCGGCAACCCTGACACCGAGGGAGGAGATTGGATCTTGGTGGA CTCGGGTTCCTTCCAACATGTCTCATCCGGCAGCGGGGTGGTGCTGGCCGTCCGTTCTAACGGGGAACTGG TGCAGCGCACAGGCATCACGTGCAGCTTGCCGCAGGGCTCCGGCTGGACCAGCATGTTAAACGGCATGTC TCGGGTGGACACCTATGGGACCGTCGCCTGGGCCGTCGACACTTATGGTGACTTGTACTTCATCAACCTG TAGACCTCGTGACAAACCTGGCAGTCACAAGCAGAAGCAAACTTTCTTGGACGTAAAAATCTCCTAAAA CTTCTCGTTCCGTAGTTGCCAGTCATGTCAATGGCAATGTTTATTGTGAAGCTATGTGACTAGGCACTCA CTAAATATTAAACAGATAAAATGTCTTCCTCTGTAAAAAAAAAAAAACCTATAGTGAGTCGTATTAAT TCTGTGCTCGC 3'

A partir de esta secuencia nucleotídica obtuvimos la secuencia aminoacídica de la subunidad menor de 31 kDa de PV2 (ver más abajo). En esta secuencia puede observarse con color celeste la secuencia Nt obtenida mediante degradación de Edman (Dreon et al., 2002), en la cual solo se diferencian en el aminoácido leucina (L). En color amarillo se muestra la ubicación del fragmento de secuencia "tríptico 2" obtenido por espectrometría de masas y con asteriscos se indican los posibles codones de stop. 
Secuencia aminoacídica de subunidad menor de PV2

Sitio de corte
$\downarrow$
MERHASIVAFLLAVLALTESQAFTSVKLPRDEHWPYSYVSVGPAGVWAVNRQNKLFYRTGTYGDNANMG SGWQFKIDGVNQVDVGRDTVAFINPSKRAMFRIEGINKANPLGASPYSWEWWTMYIGMSLKQDVRFSV RIDTDNKVQTLTWRTCWWASRITNWCYADGSYTETVTTGGSGTWITKSQLKYKSGTFGNPDTEGGDW ILVDSGSFQHVSSGSGVVLAVRSNGELVQRTGITCSLPQGSGWTSMLNGMSRVDTYGTVAWAVDTYGD LYFINL*TS*QTWQSQAEANFLGRKNLLKLLVP*LPVMSMAMFIVKLCD*ALTKY*TDKMSSSVKKKKPIV SRINSVLA

Asimismo, se pudo detectar la presencia de un péptido señal (color fucsia) y el sitio de corte identificado empleando el software Signal IP 3.0 (http:// www.cbs.dtu.dk/services/SignalP/)(Bendtsen et al., 2004). La probabilidad de que éste sea un péptido señal fue del $99 \%$ con el sitio de corte más probable entre el aminoácido 22 y 23 fenilalanina (F). Estos resultados son también coincidentes con los obtenidos por secuenciación del N-terminal que indicaban que la proteína comienza con el aminoácido fenilalanina.

\subsection{Análisis bioinformático de la subunidad menor de PV2}

La secuencia obtenida se analizó con herramientas bioinformáticas en la base de datos del Centro Nacional de Información Biotecnológica (NCBI) utilizando algoritmos de búsqueda local de alineación (BLASTX) (Altschul et al., 1997). Los resultados obtenidos no determinan la identidad de la secuencia, pero sí el valor esperable o valor $E$, que indica la confianza estadística entre secuencias (Altschul et al., 1997). El otro parámetro importante en la búsqueda de homologías es el puntaje o score entre dos secuencias que refleja la calidad de alineamiento de residuos idénticos y/o similares entre secuencias, cuanto mayor es el puntaje y menor el valor $E$, mayor será la homología entre secuencias. 
En este análisis se utilizó la base de datos no redundante GenBank CDS translations + PDB + SwissProt + PIR + PRF y el algoritmo BLASTX 2.2.24 (http:// blast.ncbi.nlm.nih.gov) (Altschul et al., 1997). Los resultados obtenidos se muestran en la tabla 4.2

Tabla 4.2: Resultados del BLAST de la subunidad menor de PV2

\begin{tabular}{|c|c|c|c|c|c|c|}
\hline $\begin{array}{l}\text { Nro } \\
\text { Acceso }\end{array}$ & Descripción & $\begin{array}{l}\text { Score } \\
\text { Máx. }\end{array}$ & $\begin{array}{l}\text { Score } \\
\text { total }\end{array}$ & $\begin{array}{l}\text { Cobertura } \\
(\%)\end{array}$ & $\begin{array}{l}\text { Valor } \\
\text { E }\end{array}$ & $\begin{array}{l}\text { Identidad } \\
(\%)\end{array}$ \\
\hline $\begin{array}{c}X P \_00259 \\
7540.1\end{array}$ & $\begin{array}{l}\text { Proteína hipotética } \\
\text { BRAFLDRAFT_78909 [Branchiostoma } \\
\text { floridae] region="TECPR"=Lámina beta } \\
\text { repetida en tectoninas de Polycephalum } \\
\text { physarum, lectina L-6 de Limulusy } \\
\text { proteínas de animales hipotéticos, } \\
\text { region="EGF_CA",dominio tipo EGF de } \\
\text { unión al calcio. }\end{array}$ & 112 & 112 & $67 \%$ & $8 e-23$ & $34 \%$ \\
\hline XP_00260 & $\begin{array}{l}\text { Proteína hipotética } \\
\text { BRAFLDRAFT_87403 [ } \text { B.floridae] } \\
\text { region="TIL"= dominio tipo inhibidor de } \\
\text { tripsina rico en cisteínas,reg="TECPR" }\end{array}$ & 110 & 163 & $67 \%$ & $4 e-22$ & $34 \%$ \\
\hline $\begin{array}{c}\text { XP_00261 } \\
2821.1\end{array}$ & $\begin{array}{l}\text { Proteína hipotética } \\
\text { BRAFLDRAFT_118410 B.floridae] reg } \\
=" \text { TECPR" }\end{array}$ & 109 & 160 & $67 \%$ & $5 e-22$ & $35 \%$ \\
\hline $\begin{array}{l}\text { ABY } 2835 \\
9.1105\end{array}$ & $\begin{array}{l}\text { Proteína tipo taquilectina [B. belcheri } \\
\text { tsingtauense] reg="TECPR" }\end{array}$ & 105 & 216 & $71 \%$ & $1 e-20$ & $38 \%$ \\
\hline $\begin{array}{c}\text { XP_00260 } \\
2245.1\end{array}$ & $\begin{array}{l}\text { Proteína hipotética } \\
\text { BRAFLDRAFT_76934 [ B.floridae] } \\
\text { region="TECPR" }\end{array}$ & 97.4 & 136 & $67 \%$ & $3 e-18$ & $28 \%$ \\
\hline XP_00259 & $\begin{array}{l}\text { Proteína hipotética } \\
\text { BRAFLDRAFT_101110 [B.floridae] }\end{array}$ & 97.1 & 235 & $67 \%$ & $3 e-18$ & $28 \%$ \\
\hline $\begin{array}{c}\text { XP_00260 } \\
7222.1\end{array}$ & $\begin{array}{l}\text { Proteína hipotética } \\
\text { BRAFLDRAFT_67980 [B.floridae] } \\
\text { region ="TIL"/(CTL) Lectina tipo C }\end{array}$ & 96.3 & 261 & $72 \%$ & $6 e-18$ & $35 \%$ \\
\hline $\begin{array}{c}\text { XP_00259 } \\
0957.1\end{array}$ & $\begin{array}{l}\text { Proteína hipotética } \\
\text { BRAFLDRAFT_129574 [B. floridae] } \\
\text { region ="TECPR" }\end{array}$ & 96.3 & 96.3 & $67 \%$ & $6 e-18$ & $28 \%$ \\
\hline $\begin{array}{c}\mathrm{XP}=00260 \\
7217.1\end{array}$ & $\begin{array}{l}\text { Proteína hipotética } \\
\text { BRAFLDRAFT_67985 [B.floridae] (CTL) }\end{array}$ & 93.2 & 133 & $68 \%$ & $5 e-17$ & $31 \%$ \\
\hline $\begin{array}{c}\text { CAI7721 } \\
5.1\end{array}$ & $\begin{array}{l}\text { Precursor de proteína de cnidario } \\
\text { relacionada taquilectinas[Hydractinia } \\
\text { echinata] region ="Hyd_WA"= lámina } \\
\text { beta; pfam06462= Lámina beta repetida } \\
\text { en tectoninas de P. physarum, lectina L- } \\
6 \text { de Limulus }\end{array}$ & 88.6 & 146 & $71 \%$ & $1 e-15$ & $36 \%$ \\
\hline $\begin{array}{c}\text { AAX8477 } \\
5.1\end{array}$ & $\begin{array}{l}\text { Proteína tipo taquilectina [Hydractinia } \\
\text { echinata] / pfam06462 }\end{array}$ & 82.8 & 144 & $68 \%$ & $7 e-14$ & $33 \%$ \\
\hline
\end{tabular}


Como puede observarse en la tabla, encontramos únicamente homología con proteínas hipotéticas de Branchiostoma floridae y B. belcheri (Eukaryota; Metazoa; Chordata; Cephalochordata; Branchiostomidae; Branchiostoma) y con una taquilectina de Hydractinia echinata (Eukaryota; Metazoa; Cnidaria; Hydrozoa; Hydroida; Anthomedusae; Hydractiniidae; Hydractinia). Las regiones de homología de estas secuencias eran coincidentes principalmente con un dominio conservado "TECPR" de regiones repetidas de lámina $\beta$ presente en lectinas. Estos resultados fueron luego analizados alineando las secuencias con el programa Clustal W 2.0.12 (European Bioinformatic Institute, http://www.ebi.ac.uk/clustalw) lo que permitió relacionar la secuencia de la subunidad menor de PV2 con seis proteínas, todas ellas con función lectina, provenientes de diferentes organismos (tabla 4.3).

Entre ellas se destacan la lectina L-6 de Limulus, que es similar a las taquilectinas de Tachypleus tridentatus que median la inmunidad innata y a las tectoninas de Polycephalum physarum (tabla 4.3). También otras regiones mostraron homología con el factor de crecimiento epidérmico de unión a calcio y con dominios con función de inhibidor de la tripsina.

Tabla 4.3: Alineación de la secuencia de la subunidad menor de PV2 con proteínas relacionadas de otros organismos

\begin{tabular}{|c|c|c|c|c|}
\hline Secuencia & $\begin{array}{c}\text { Longitud } \\
(\text { AA })\end{array}$ & Secuencia & $\begin{array}{c}\text { Longitud } \\
(A A)\end{array}$ & Score \\
\hline PV2 & 346 & Tectonina 1 & 217 & 10 \\
\hline PV2 & 346 & CTRN & 279 & 21 \\
\hline PV2 & 346 & TPL-1 & 256 & 19 \\
\hline PV2 & 346 & Lectina L-6 & 221 & 12 \\
\hline PV2 & 346 & LEC_SUBDO & 238 & 10 \\
\hline PV2 & 346 & FEL & 238 & 15 \\
\hline
\end{tabular}

Tectonina 1 de Polycephalum physarum (número de acceso GenBank: AF041455); CTRN, taquilectina del cnidario Hydractinia echinata (GenBank AJ920381); TPL-1, lectina de plasma del cangrejo herradura japonés Tachypleus tridentatus (Genbank AAF74773); Lectina -L6 de cangrejo herradura Limulus polyphemus (Genbank A56941); LEC_SUBDO, lectina de esponja Suberites dumuncula (CAD79378); FEL, Lectina de huevo de pez Cyprinus carpio (P68512). 
De todas ellas, la estructura primaria de la proteína presentó la mayor similitud con las lectinas del tipo taquilectina del Cnidario Hydractinia echinata y del crustáceo Tachypleus tridentatus (cangrejo herradura japonés).

\subsection{Discusión}

Si bien PV2 había sido parcialmente caracterizada bioquímicamente, no se había estudiado en sus aspectos estructurales. La posibilidad de obtener el oligómero de PV2 en su forma nativa de una fuente natural, permitió realizar su análisis detallado de organización estructural.

En primer lugar se observó que presentaba 32 cisteínas totales y pI era de 6,2. La subunidad menor exhibió varias isoformas que podrían deberse a modificaciones postraduccionales como fosforilaciones o glicosilaciones como fuera observado en el caso de escalarina y ovorrubina (Ituarte et al., 2010). En esas perivitelinas se vieron varias isoformas para cada subunidad que al ser deglicosiladas mostraron una drástica simplificación con spots de similar PM pero distinto pI, sugiriendo la existencia de más de un polipéptido, hecho que no ha sido dilucidado aún en el caso de la subunidad menor de PV2.

El análisis mediante SAXS permitió elaborar el primer modelo de baja resolución para una neurotoxina proteica de huevo. El $R_{G}$ obtenido está de acuerdo con el esperado para un oligómero compacto de 400 kDa de masa molecular. Por otra parte, las distribuciones de pares de distancia de los datos de SAXS fueron concordantes con los resultados de microscopía electrónica, confirmando la ausencia de agregados supramoleculares.

La OR era, hasta esta tesis, el único modelo de perivitelina reportado para invertebrados (Dreon et al., 2008). Comparando ambas perivitelinas se pueden observar similitudes en su forma alargada, compacta pero evidentemente con dimensiones diferentes, acordes a su diferente masa molecular.

El espectro de fluorescencia de Trp para PV2 nativa indicó que en "promedio" los anillos indólicos se encontrarían en un ambiente hidrofóbico: 
además, los resultados de apagamiento o quenching por acrilamida no sólo confirman esta conclusión sino que apoyan la existencia de una única clase de Trp, dato inusual para una proteína de alto PM.

Por otra parte, los experimentos de fluorescencia de Trp y CD concuerdan con los gráficos de Kratky (Iq vs. $q^{2}$ ) obtenidos del análisis de los datos de SAXS ya que todos indican que el oligómero presenta una estructura compacta y bien plegada.

En conjunto estos resultados indican que PV2 es un octámero compacto y bien plegado con sus subunidades formando cuatro heterodímeros de 98 kDa cada uno estabilizado por puentes disulfuro intercatenarios. Los heterodímeros están unidos entre sí por fuerzas de tipo no covalente para formar la partícula nativa. Interacciones adicionales en la estructura cuaternaria determinan las características de las proteínas (Jaenicke, 1996a). Así, la carotenoproteína crustacianina de Homarus gammarus también tiene una estructura de octámero de dímeros pero en este caso posee una molécula de carotenoide en cada dímero necesaria para mantener la estructura (Dellisanti et al., 2003).

Respecto a la estructura primaria de la proteína, si bien las secuencias $\mathrm{Nt}$ de las subunidades de PV2 no habían mostrado homología con otras proteínas (Dreon et al., 2002), al analizar la secuencia aminoacídica completa de la subunidad menor en la presente tesis, se encontró homología con proteínas presentes en Branchiostoma (Cephalochordata) e Hydractinia (Cnidaria) principalmente con dominios de lectinas.

Las lectinas son proteínas que reconocen patrones específicos de carbohidratos. Entre otras funciones, son cruciales en el sistema inmune innato de varios animales desde las esponjas a los vertebrados. En invertebrados, el sistema inmune innato es el único medio de defensa bioquímico contra los patógenos (Hoffmann et al., 1999). Las lectinas reconocen patrones de hidratos de carbono presentes en la superficie de los potenciales patógenos, iniciando la respuesta inmune (Rudd et al., 2001). La subunidad de PV2 presentó homología con un tipo de lectinas llamado taquilectinas, que presentan muy amplia distribución en la 
naturaleza. Así, recientemente un gen relacionado con taquilectina fue identificado en la esponja Suberites dumuncula (Schroder et al., 2003), mientras que se observaron proteínas de unión a bacterias con características de taquilectinas en los huevos de peces (Galliano et al., 2003) indicando su presencia también en los vertebrados. Estructuralmente, las taquilectinas se caracterizan por tener seis repeticiones en tándem de 31 a 37 aminoácidos ácidos, formando una estructura de barril beta (Rini \& Lobsanov, 1999). Las taquilectinas del cangrejo herradura Tachypleus tridentatus son quizás las mejor caracterizadas tanto a nivel estructural como funcional (Kawabata \& Iwanaga, 1999, Chen et al., 2001, Iwanaga et al., 1998). Dos de ellas, la taquilectina-1 presente en hemocitos (antes llamada lectina L-6) (Saito et al., 1995) y la lectina de hemolinfa TPL-1 (Chen et al., 2001) son homólogas entre sí y, a su vez, con lectinas del moho Polycephalum physarum llamadas Tectoninas I y II localizadas en la superficie exterior de la membrana plasmática. Independientemente del organismo donde se expresan, las tahylectinas facilitan la fagocitosis de bacterias y presentan un dominio homólogo al del factor de crecimiento epitelial (EGF) vinculado al calcio (Huh et al., 1998)

Otra taquilectina con alta homología con la subunidad menor de PV2 es la TL-P que, al igual que PV2, se encuentra en el fluido perivitelino de los huevos en este caso del cangrejo Tachypleus tridentatus. Presenta menor actividad antibacteriana que las de la hemolinfa y alta similitud de secuencia con la lectina FEL de la carpa. Se cree que esta taquilectina participaría en el desarrollo del embrión y no en la defensa contra patógenos (Nagai et al., 1999).

Si bien la secuencia de PV2 presentó homología con la Taquilectina-1 de $T$. tridentatus, el mejor alineamiento fue con la taquilectina del cnidario Hydractinia echinata que, a pesar de tener una alta similitud estructural con las taquilectinas, parece ser una excepción, ya que no participaría en la inmunidad sino en la señalización durante el desarrollo neuronal (Mali et al., 2006). Llamativamente, no encontramos homología con otras toxinas proteicas de gasterópodos como la ecotoxina 2 del caracol marino Monoplex (Kawashima et al., 2003) o las pequeñas conotoxinas de los Conidae. 
En base al análisis de la secuencia podemos concluir que la subunidad menor de PV2 de $31 \mathrm{kDa}$ presenta semejanzas con un grupo de lectinas de invertebrados con función en el sistema inmunológico innato y en el desarrollo embrionario. Por ello, podemos sugerir que esta subunidad no se encontraría involucrada directamente en la neurotoxicidad demostrada para la proteína nativa (capítulo 6), sino que participaría de la defensa de los huevos frente a patógenos. En apoyo a esta hipótesis, observamos que a pesar de administrar ambas subunidades por vía oral a ratas, sólo la subunidad mayor fue capaz de ingresar al organismo o al menos de generar anticuerpos circulantes (ver capítulo 6). Hace falta realizar experimentos de validación específicos con las subunidades aisladas para poder corroborar estas hipótesis. 
CAPITULO 5

Estabilidad 


\section{CAPITULO 5: Estabilidad}

\subsection{Introducción}

La reproducción estacional de Pomacea canaliculata está afectada por los cambios de temperatura ambiental (Albrecht et al., 1999, 2004; Pizani et al., 2005). Al depositar sus huevos por encima del agua sobre la vegetación emergente, rocas u otros sustratos, los embriones quedan inevitablemente expuestos directamente al sol durante varias horas al día (fig. 5.1). Esto es un fuerte factor de estrés térmico al que se agrega el de la exposición a la radiación ultravioleta que puede causar efectos subletales, como deformidades embrionarias o pequeño tamaño del embrión dentro de masas de huevos, por ejemplo, en huevos de moluscos expuestos en el intermareal, los que podrían ser sinérgicos con otros factores de estrés ambiental (Biermann et al., 1992, Pahkala et al., 2002, Przeslawski et al., 2004)

Figura 5.1: Puestas de huevos de P. canaliculata

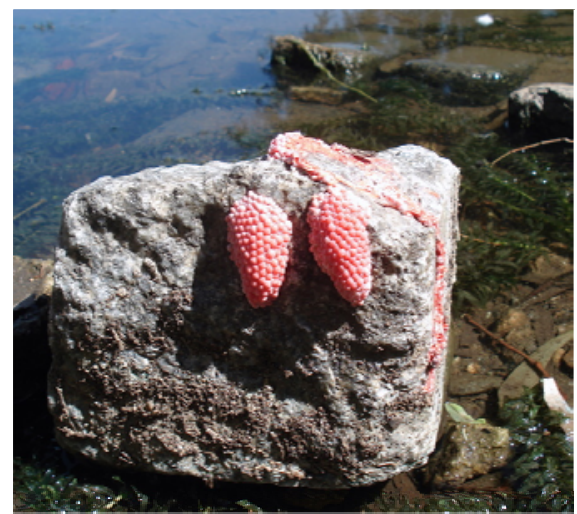

Los cálidos veranos de la región neotropical plantean un enorme desafío para los huevos depositados en las rocas, que fácilmente corren el riesgo de desecación y muerte térmica por sobrecalentamiento. Estos caracoles han desarrollado adaptaciones bioquímicas que les proporcionan protección frente a 
estas duras condiciones ambientales. Entre estas adaptaciones los embriones se encuentran rodeados del FPV que, hasta el momento de comenzar esta tesis, se sabía que actuaba no sólo como fuente nutricia, sino también de protección frente a factores abióticos (Heras et al., 1998, 2007, Dreon et al., 2004b, 2010).

Al estar las perivitelinas expuestas a estas altas temperaturas, es fácil suponer que posean una estabilidad particular a estas condiciones, ya que las proteínas se desnaturalizan cuando pierden su estructura tridimensional (conformación química), es decir su plegamiento característico, que a su vez determina tanto su interacción con el entorno como sus funciones. Por todo esto, es importante conocer la estabilidad de esta estructura. Pese a ello, los estudios de estabilidad en perivitelinas estaban circunscriptos a la OR de $P$. canaliculata y la escalarina, principal perivitelina de Pomacea scalaris, las que efectivamente, resultaron poseer una elevada estabilidad térmica y también elevada estabilidad frente a variaciones extremas de pH (Dreon et al., 2004a, 2004b, 2006, 2007 ", Ituarte, 2010, Ituarte et al., 2008).

En este capítulo estudiamos la estabilidad estructural de PV2 frente a diferentes agentes físicos y químicos. En particular, se determinaron los efectos de la urea, la temperatura, el pH y la proteólisis con proteinasa $\mathrm{K}$ mediante una combinación de técnicas que incluyeron fluorescencia, $C D, S A X S$ y electroforéticas.

Esta metodología permitió estudiar la estructura secundaria y terciaria, la exposición de los residuos de Trp al entorno, la globularidad de la proteína, así como los cambios en sus dimensiones frente a los diferentes agentes de perturbación. 


\subsection{Estabilidad frente a la acción de la urea:}

La urea es un agente desnaturalizante que provoca una disminución en el grado de hidratación de los grupos iónicos superficiales de la proteína, rompiendo los puentes de hidrógeno o las interacciones electrostáticas. El efecto de este agente sobre los diversos niveles estructurales de PV2 se observó mediante el empleo de varias técnicas experimentales cuyos resultados se detallan a continuación.

Con el fin de determinar el grado de exposición al solvente de los residuos de Trp, se estudió el espectro de emisión fluorescente del grupo indólico a diferentes concentraciones de urea. Los espectros de fluorescencia de Trp obtenidos para PV2 en diferentes concentraciones de urea se muestran en la figura 5.2.A.

De los espectros presentados en la figura 5.2.A pudimos observar dos comportamientos distintos. Por un lado, a bajas y medianas concentraciones de urea (hasta 4,5 M) se puede ver una reducción en la intensidad de fluorescencia y un pequeño, pero notable, corrimiento del valor medio del espectro de emisión, que estaría asociado a una exposición progresiva de los anillos indol del Trp al solvente polar (fig. 5.2.B).

Por otro lado, el comportamiento de PV2 expuesta a altas concentraciones de este caótropo mostró un fuerte corrimiento al rojo (longitudes de onda mayores) característico de la exposición del anillo indólico a un solvente de alta polaridad, acompañado por un incremento de la emisión de fluorescencia que probablemente se deba a la eliminación de interacciones locales de los Trp que estarían reduciendo la emisión (quenching) en el estado nativo.

La presencia de cambios estructurales a altas concentraciones de urea es concordante con lo observado con el número de cisteínas expuestas (capítulo 4, fig. 4.2); donde puede apreciarse que por encima de 4,5 M urea ocurre un incremento considerable de residuos cisteína expuestos a la reducción, indicando algún tipo de 
cambio en su conformación que hace que puentes S-S o grupos SH que estaban ocluidos en estados cercanos al nativo queden expuestos al solvente.

Figura 5.2: Efecto de la urea sobre el espectro de emisión de fluorescencia de Trp de PV2 A: Espectros de fluorescencia a distintas concentraciones de urea (ver leyenda). B: Valor medio de distribución espectral se refiere a $\Sigma(\Lambda F(\Lambda)) / \Sigma F(\Lambda)$, donde $F(\Lambda)$ corresponde a la intensidad de la fluorescencia dada para una determinada longitud de onda $(\Lambda)$ (círculo cerrado). Intensidad máxima en diferentes concentraciones de urea (círculo abierto).
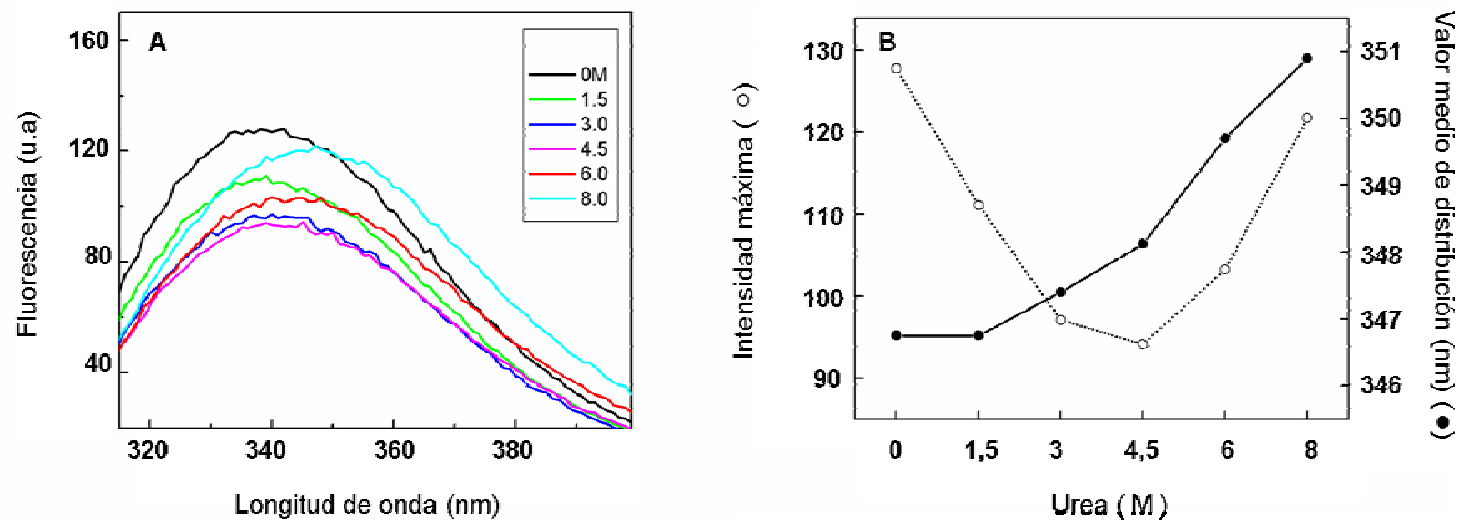

Experimentos de nCD pusieron en evidencia que la estructura terciaria de la proteína se pierde casi por completo a una concentración de $6 \mathrm{M}$ urea, tal como puede verse por la pérdida de señal dicroica mostrada en la figura 5.3.

Figura 5.3: Espectros de NCD de PV2 frente a urea

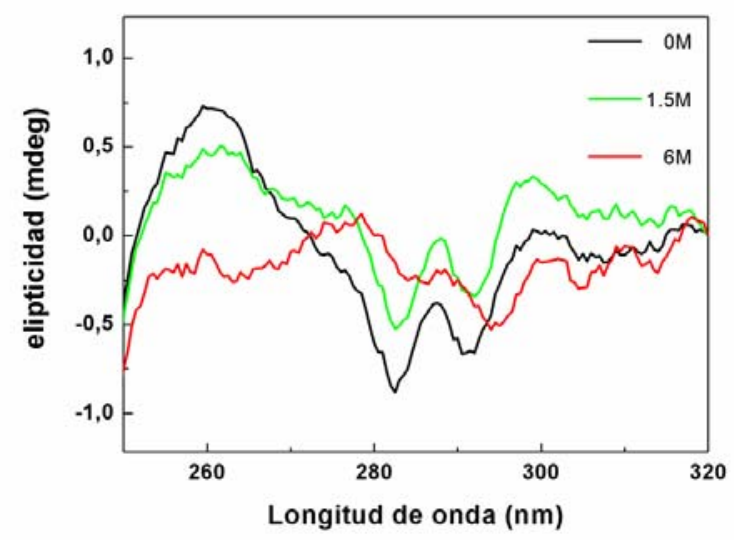


El efecto desnaturalizante en la estructura cuaternaria de PV2 fue estudiado mediante la técnica SAXS. En la figura 5.4.A se pueden ver los datos de dispersión obtenidos a diferentes concentraciones de urea. A partir de ellos, se calcularon los $R_{G}$ para cada concentración los que se usaron como indicativo del tamaño característico de la proteína.

Los $R_{G}$ se mantuvieron constantes en un valor de $44 \pm 1 \AA$ entre 0 y $2 M$ urea, mientras que para concentraciones más altas el radio de giro aumentó gradualmente hasta $66 \pm 5 \AA$ a $6 \mathrm{M}$ de urea (fig. 5.4.B).

En la figura 5.4.C puede observarse el gráfico de Kratky de estos datos, donde se evidencia la pérdida total de globularidad de la proteína cuando se la expone a una concentración $6 \mathrm{M}$ urea.

Figura 5.4: A: Datos SAXS de la proteína plegada (línea negra) y desplegada a 6M urea (línea roja) (la curva continua sirve como guía para el ojo). B: Variaciones de radio de giro de la partícula en función de la concentración de urea. C: Gráfico de Kratky de la proteína a 0 y $6 \mathrm{M}$ urea.
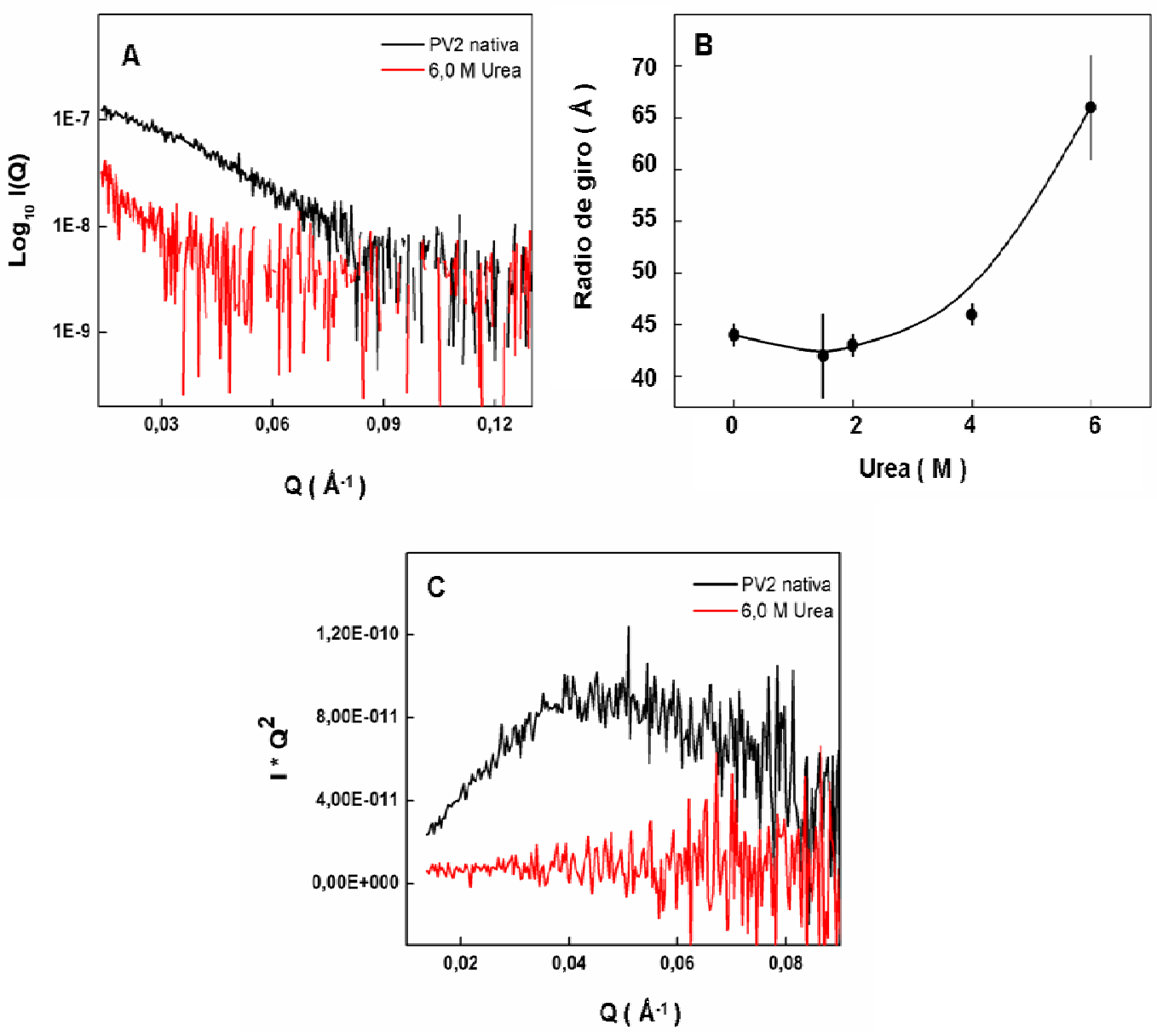


\subsection{Estudios de estabilidad térmica:}

La exposición de las proteínas solubles en medios acuosos a temperaturas crecientes provoca un aumento de su energía vibracional, destruyendo las interacciones débiles entre sus componentes y desorganizando su estructura, de forma que el interior hidrofóbico interactúa con el medio acuoso.

De forma similar a los experimentos realizados a concentraciones crecientes de urea, la fluorescencia de los Trp de PV2 se midió a temperaturas crecientes desde $20^{\circ} \mathrm{C}$ a $70^{\circ} \mathrm{C}$.

Los espectros mostraron que PV2 es estable hasta los $60^{\circ} \mathrm{C}$ como puede observarse en la figura 5.5.A. A mayores temperaturas se observó un corrimiento del espectro hacia el rojo junto con una disminución de la intensidad de fluorescencia que indica la mayor exposición de los residuos de Trp al medio acuoso (fig. 5.5.B).

Figura 5.5: Efecto de la temperatura sobre el espectro de emisión de fluorescencia de Trp de PV2.

A: Espectro de fluorescencia a distintas temperaturas. B: Valor medio de distribución espectral $(\Sigma(\Lambda$ $F(\Lambda)) / \Sigma F(\Lambda))$.
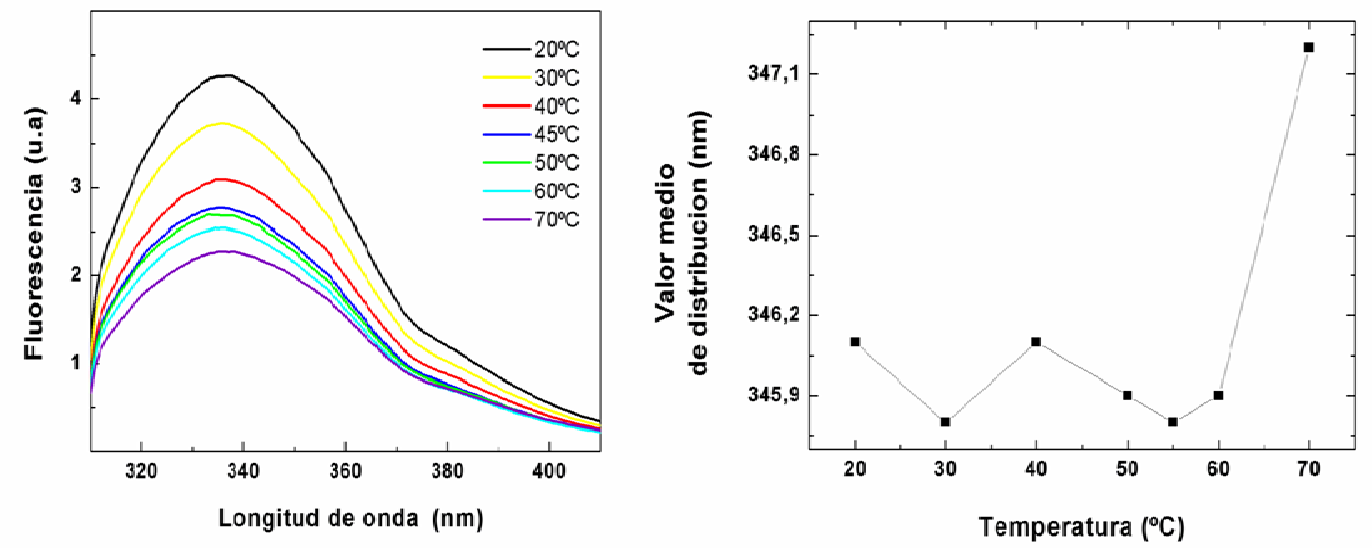

Los espectros obtenidos para PV2 a diferentes temperaturas mediante $f C D$ se representan en la figura 5.6.A. La estimación de las estructuras secundarias utilizando los algoritmos K2D (Andrade et al., 1993) y Contin (Provencher \& Glockner, 1981) indican un notable incremento en la contribución de la estructura 
de lámina- $\beta$ por encima de $60^{\circ} \mathrm{C}$ (tabla 5.1). Una posible explicación para este comportamiento, podría ser la presencia de estructuras del tipo poli-prolinas durante el desplegado de la proteína, dado que los algoritmos empleados difícilmente podrían diferenciarla de la estructura de lámina- $\beta$.

Tabla 5.1: Contenido de estructura secundaria de PV2 expuesta a temperaturas crecientes.

\begin{tabular}{|c|c|c|c|c|c|c|}
\hline \multirow{2}{*}{$\begin{array}{c}\mathbf{T} \\
{ }^{\circ} \mathrm{C}\end{array}$} & \multicolumn{2}{|c|}{$\begin{array}{c}\text { Hélice } \alpha \\
(\%)\end{array}$} & \multicolumn{2}{c|}{$\begin{array}{c}\text { Lámina } \beta \\
(\%)\end{array}$} & \multicolumn{2}{c|}{$\begin{array}{c}\text { Ovillo } \\
\text { aleatorio }\end{array}$} \\
\cline { 2 - 7 } & $\mathbf{K}^{*}$ & $\mathbf{C}^{*}$ & K & C & K & C \\
\hline 20 & 21 & 22 & 22 & 28 & 56 & 49 \\
\hline 60 & 21 & 15 & 24 & 38 & 55 & 47 \\
\hline 70 & 9 & 6 & 43 & 47 & 48 & 46 \\
\hline
\end{tabular}

\section{$\mathrm{K}^{*}$ : Algoritmo k2D $\mathrm{C}^{*}$ :Algoritmo Contin}

La importante estabilidad térmica de PV2 quedó también puesta de manifiesto al estudiar la evolución térmica de la señal dicroica a $222 \mathrm{~nm}$ (característica de la presencia de hélices $\alpha$ ). Estos experimentos confirmaron que la Tm de PV2 es de $\sim 70{ }^{\circ} \mathrm{C}$, un valor notablemente elevado para un organismo notermófilo (fig. 5.6.B).

Figura 5.6: Efecto de la temperatura sobre el espectro de $f C D$ de PV2. A: Espectro $f C D$ a 20,60 y $70^{\circ} \mathrm{C}$. B: Desplegado térmico de PV2 siguiendo la elipticidad de los espectros de CD a $222 \mathrm{~nm}$.
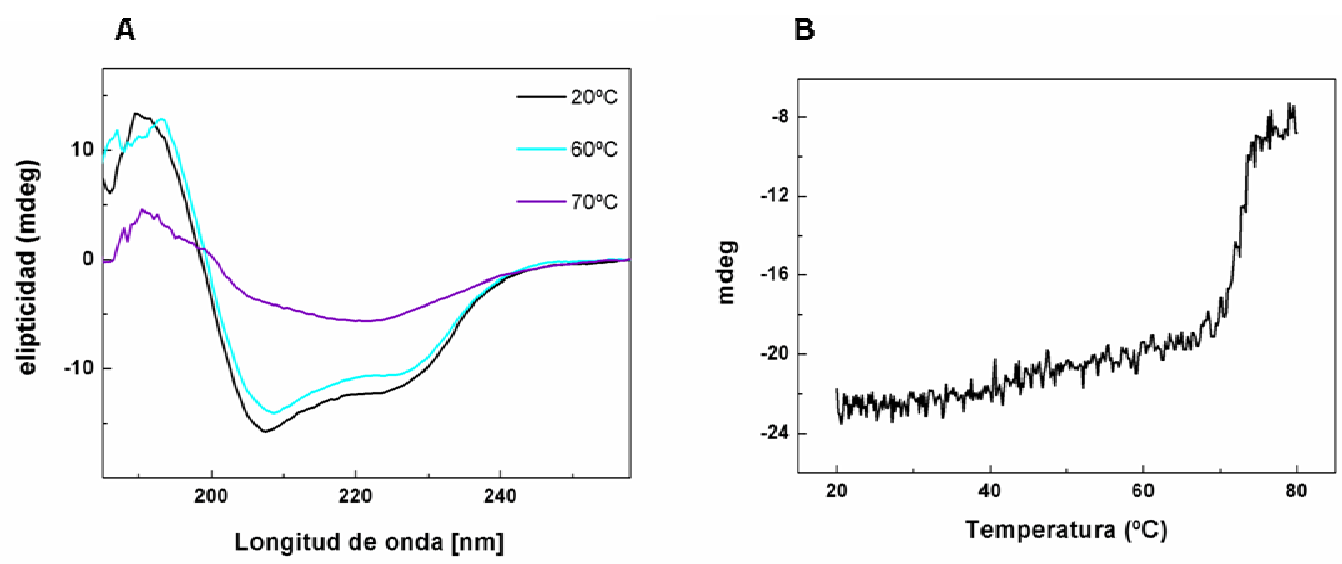
Los espectros de nCD mostraron que hasta $60^{\circ} \mathrm{C}$ no hay pérdida de la estructura terciaria de la proteína, a $65^{\circ} \mathrm{C}$ empiezan a evidenciarse cambios en el espectro pero con pérdida solo parcial de estructura (fig. 5.7).

Figura 5.7: Efecto de la temperatura sobre el espectro de nCD de PV2

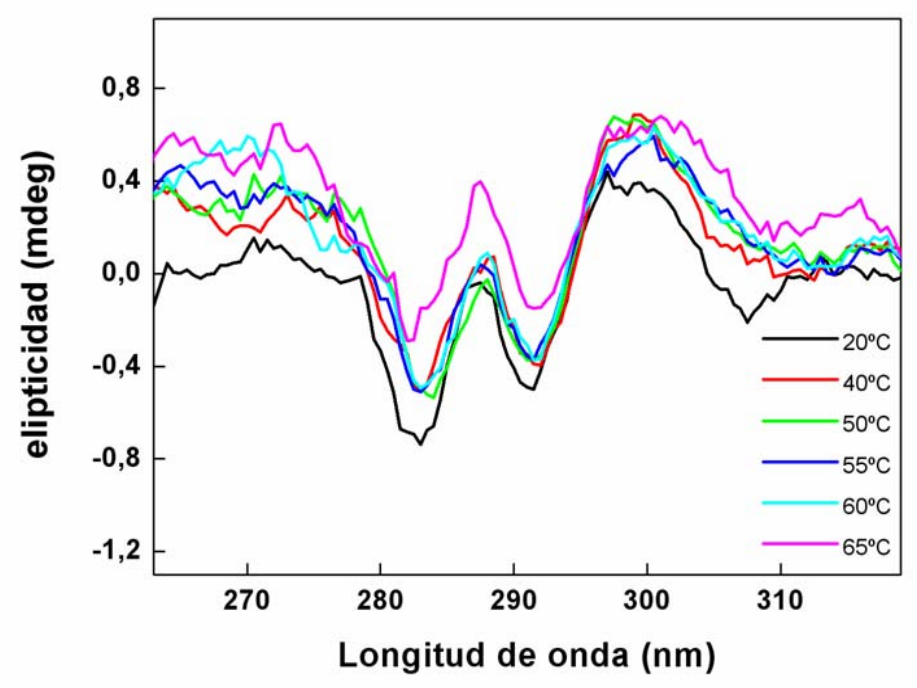

Del mismo modo, el análisis de los cambios en la estructura cuaternaria por efecto de la temperatura mediante SAXS mostraron una pérdida gradual de globularidad reflejado en el comportamiento del gráfico de Kratky y en el aumento simultáneo de $R_{G}$ que alcanzan los $52 \pm 1 \AA$ a $65{ }^{\circ} \mathrm{C}$, es decir cerca del $20 \%$ de aumento (fig. 5.8). 
Figura 5.8: Efecto de la temperatura sobre el tamaño y forma de PV2 determinado por medidas SAXS. A: Datos SAXS; B: Variaciones de $R_{G}$ de PV2 por efecto de temperaturas crecientes; C: Gráfico de Kratky de los datos de A.
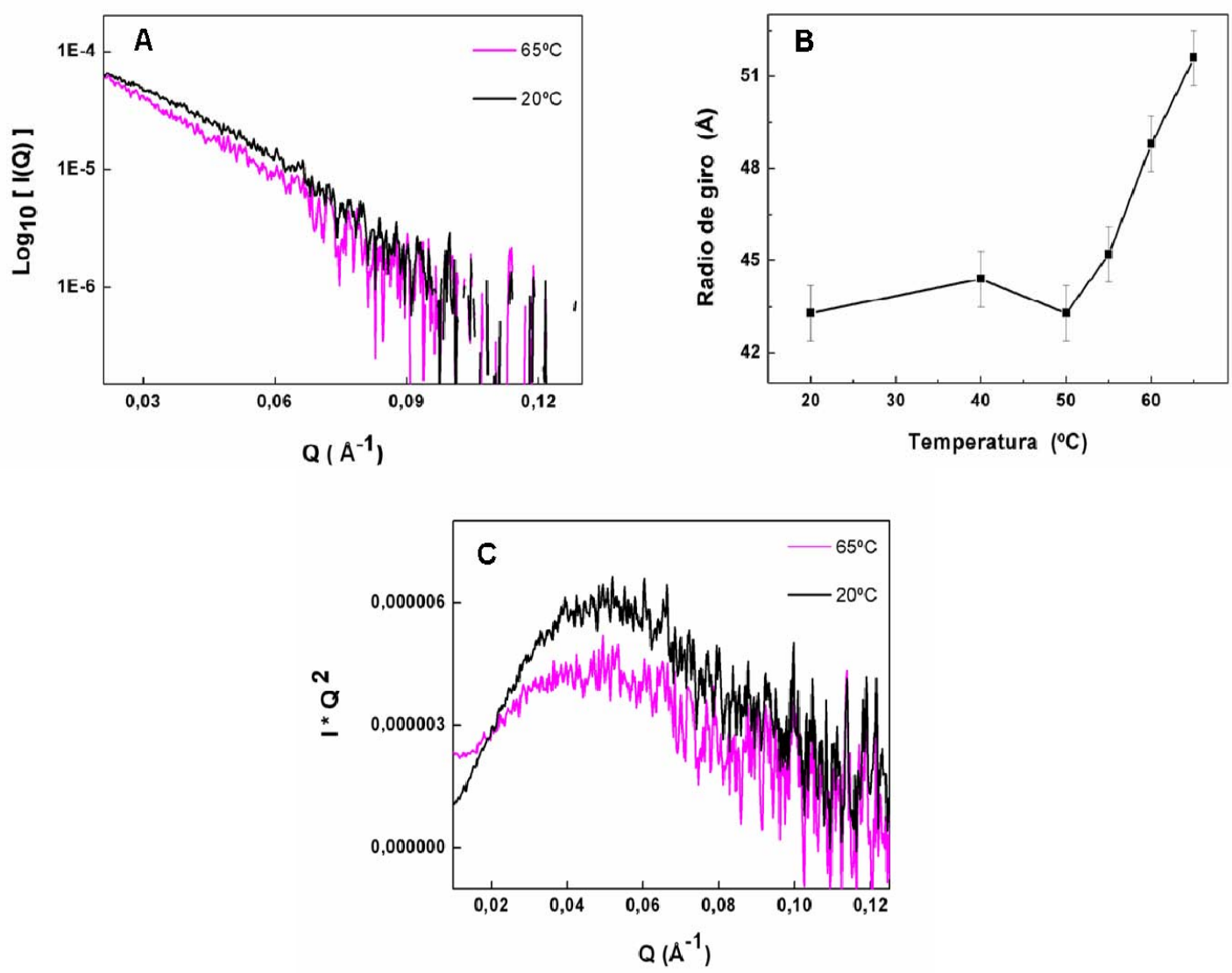

\subsection{Efecto del pH sobre PV2:}

El pH además de afectar la envoltura acuosa de las proteínas, también afecta la carga eléctrica de los grupos ácidos y básicos de las cadenas laterales de los aminoácidos, eliminando o activando interacciones electrostáticas que estabilizan o desestabilizan la estructura terciaria.

La emisión de fluorescencia del Trp fue utilizada para evaluar la desnaturalización ácido-básica de PV2. Para esto se midieron los espectros de emisión luego de incubar la proteína durante $14 \mathrm{~h}$ en buffers de $\mathrm{pH}$ entre 2,0 y 12,0 (fig. 5.9). 
No se observaron desplazamientos de los máximos de emisión, excepto un muy leve corrimiento a pH 12,0 indicativo de exposición al solvente de los Trp (fig. 5.9.B). Sólo se observaron alteraciones en la intensidad del espectro a pH alcalinos; reflejadas a partir de $\mathrm{pH} 8,0$, en una marcada disminución de la intensidad de fluorescencia.

Figura 5.9: Efecto del pH sobre el espectro de emisión de fluorescencia del Trp de PV2.

A: Espectro de de fluorescencia a diferentes valores de pH. B: Valor medio de distribución espectral (círculo cerrado), intensidad máxima (círculo abierto).
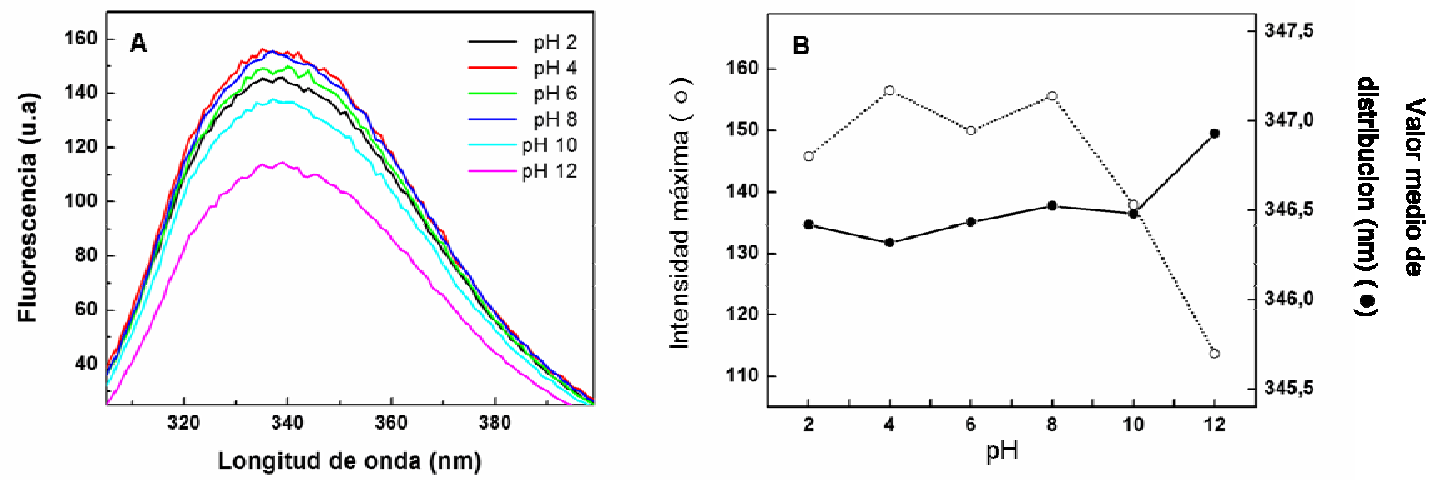

La técnica SAXS también fue utilizada para estudiar el efecto del pH sobre la estructura cuaternaria de PV2 (fig. 5.10.A). La variación del Rg de PV2 en función del pH se muestra en la figura 5.10.B, en la cual puede observarse que el $R_{G}$ disminuye levemente a valores superiores a pH 8,0.

Por otro lado, a pH ácidos se observa un incremento del $R_{G}$ hasta alcanzar un valor de $60 \AA$ a pH 2,0 que sería indicativo de una expansión de la molécula.

La pérdida gradual de globularidad se aprecia en los gráficos de Kratky (fig. 5.10.C) tanto a pH básicos (pH 10,0 y 12,0) como ácidos (pH 4,0). Sin embargo sólo a pH 2,0 la globularidad se altera significativamente apartándose la curva de Kratky de la típica forma de campana esperada para proteínas globulares. 
Figura 5.10: Efecto de pH sobre la estructura cuaternaria de PV2 determinada por SAXS. A: Datos SAXS de PV2 expuesta a pH entre 2,0 y 12,0 (ver leyenda); B: Variaciones del $R_{G}$ de PV2 a distintos pH; C: Gráfico de Kratky de los datos de dispersión de PV2 a esos pH.
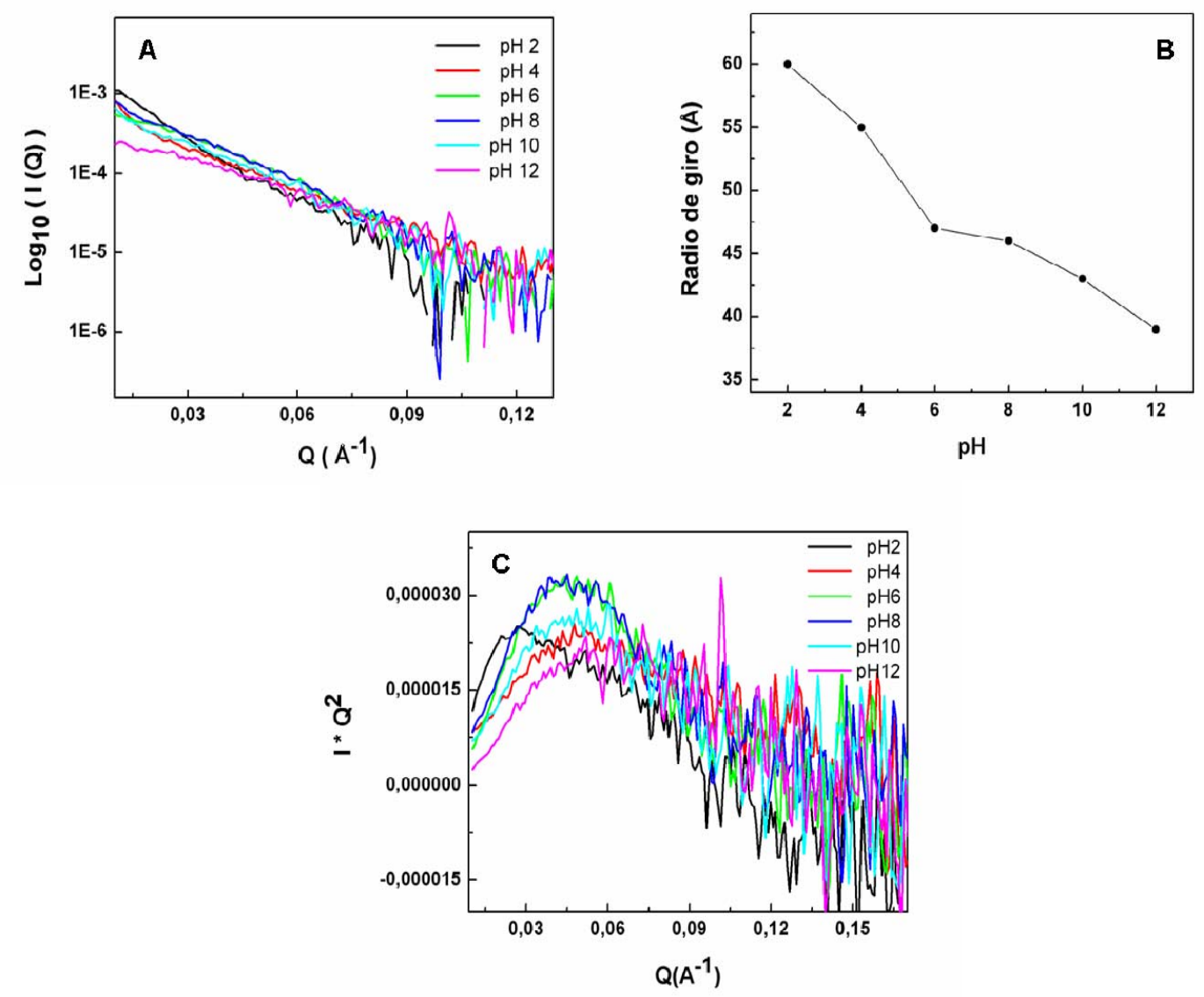

Los efectos observados sobre la estructura cuaternaria (ligera reducción de $\mathrm{R}_{G}$ a pH básico y fuerte desplegado a $\mathrm{pH} 2$ 2) sugieren que la disminución de señal de emisión del Trp a pH > 8 podría deberse a una exposición parcial de los residuos al solvente. Sin embargo, observando una fuerte variación de $R_{G}$ a pH 2, la pequeña variación en el espectro de emisión sugiere que aún en un escenario donde las subunidades de PV2 se encuentran desplegadas, el entorno de los residuos de Trp conserva características casi nativas.

De estos experimentos podemos concluir que la PV2 es estable en un amplio rango de $\mathrm{pH}$ sin que fuera posible observar el desplegado completo del oligómero a ninguno de los pH estudiados. 


\subsection{Susceptibilidad de PV2 frente a la proteinasa K:}

Para inferir la exposición relativa de las subunidades de la proteína en medio acuoso, se analizó su susceptibilidad a la proteólisis con proteinasa $K$, una proteasa inespecífica.

La incubación de PV2 en presencia de la proteasa (ver detalles en sección 3.6.6) fue seguida por geles SDS-PAGGE cuyo análisis mostró una extensa degradación de la subunidad mayor de 67 kDa (fig. 5.11); sin embargo, la subunidad menor de $31 \mathrm{kDa}$ fue resistente al clivaje por la proteasa en nuestras condiciones experimentales.

Estos resultados podrían indicar que la subunidad menor se encuentra plegada y ubicada de tal manera que no queda expuesta al medio acuoso.

Figura 5.11: Susceptibilidad de PV2 a la digestión con proteinasa K. Una solución de PV2 $(0,25 \mathrm{mM})$ se incubó con diferentes concentraciones de proteinasa $K$. Los productos de digestión pueden observarse en el gel de poliacrilamida SDS (4-20\%).

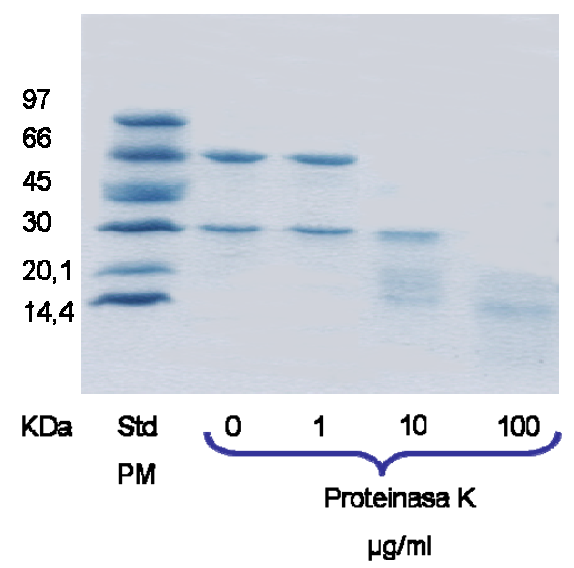

\subsection{Discusión}

Los estudios de estabilidad estructural de las proteínas son una de las claves para comprender su funcionamiento. Por lo tanto, investigamos el efecto de la temperatura y dos agentes desnaturalizantes químicos para inducir la 
desnaturalización de PV2 y completamos este estudio evaluando la susceptibilidad a la proteólisis de la proteína nativa.

El estudio de termoestabilidad presenta un valor añadido en esta proteína en particular porque, como ya fuera mencionado, los huevos de este caracol están expuestos a altas temperaturas y radiación solar directa, pese a lo cual los embriones se desarrollan normalmente. La alta resistencia a la desnaturalización térmica en esta perivitelina sumada a la anteriormente observada para la otra proteína mayoritaria del huevo, la $O R$, podría constituir una ventaja adaptativa relacionada con el comportamiento de oviposición de puestas aéreas de huevos.

El efecto de los otros caótropos estudiados completó la visión de la estabilidad de esta proteína. Así, los cambios en los espectros de Trp durante el desplegado inducido por urea indican la exposición de los anillos indol al medio polar circundante y la existencia de fuertes interacciones internas de quenching en el estado nativo. Por el contrario, el desplegado de PV2 en función de la temperatura y pH básico dio lugar a una constante disminución de la emisión de fluorescencia de Trp sugiriendo que la interacción responsable de la extinción parcial de emisión de Trp en el estado nativo no puede ser completamente removida en estas condiciones. Resulta interesante que a lo largo de todo el rango de temperatura y $\mathrm{pH}$ estudiado no se hayan observado corrimientos significativos en los máximos de absorción.

En síntesis podemos decir que la PV2 presenta una amplia estabilidad conformacional entre $\mathrm{pH} \mathrm{4,0} \mathrm{y} 10,0$ siendo más sensible a pH ácido; una elevada termoestabilidad hasta $60^{\circ} \mathrm{C}$, manteniendo intacta su estructura secundaria y terciaria, y una baja estabilidad en presencia de 6M urea, frente a la que pierde completamente su estructura terciaria y su forma globular.

El tratamiento con la proteinasa $K$ evidenció que la subunidad mayor es más susceptible a la proteólisis, lo que indica que sería menos compacta o ubicada más hacia el exterior de la partícula o en una región al menos más expuesta a la digestión por esta proteasa. 
Los efectos de estos caótropos sobre la estructura cuaternaria sugieren que la PV2 sufre un desplegado pero sin que la proteína se desensamble, ya que curiosamente las perturbaciones estructurales inducidas por urea, $\mathrm{pH}$ ácidos y temperatura provocaron un aumento de tamaño de la estructura cuaternaria y no la disminución que se esperaría por el desmontaje del oligómero. Este comportamiento sería compatible con la posible liberación de los heterodímeros, pero sin desmontar por completo a la proteína, probablemente debido a que los puentes disulfuro mantienen unidas sus subunidades (como comentamos en el capítulo 4) y reducen la entropía conformacional.

La evolución selecciona la secuencia final de una proteína por compromiso entre estructuras que brinden a la vez rigidez (estabilidad) y flexibilidad (plegado, función o degradación). Aparte del efecto entálpico (interacciones intermoleculares débiles), la entropía puede jugar un papel en la estabilización mediante la reducción de la flexibilidad (puentes cistina, mayor contenido de prolina), o por la liberación del agua de los residuos que quedan enterrados luego del plegamiento y la asociación entre subunidades (Jaenicke, 2000). Aún no se han podido determinar las estrategias generales de estabilización de proteínas, pero existen ciertas contribuciones a la estabilidad que han logrado ser elucidadas mediante el análisis de proteínas extremadamente estables. De hecho, el estudio de la estructura y estabilidad de proteínas homólogas de organismos mesófilos y extremófilos ha puesto de manifiesto que el incremento de estabilidad de una proteína se puede acumular a partir de las interacciones locales, estructura secundaria o supersecundaria, embalaje y acoplamiento de los dominios, asociación de las subunidades y la conjugación con grupos prostéticos tales como hidratos de carbono (Jaenicke, 1996a, 1996b). La estabilidad de PV2 parece caer en esta estrategia evolutiva general.

Tanto PV2, OR así como la escalarina son perivitelinas con elevada estabilidad térmica (Dreon et al., 2007, Ituarte, 2010), que puede asociarse a múltiples factores, aunque la hipótesis comúnmente aceptada es que se debe a la mayor rigidez de conformación de la estructura molecular (Tehei et al., 2005). 
Existen muchas proteínas con una elevada estabilidad estructural frente a condiciones extremas de temperatura y $\mathrm{pH}$, entre ellas los inhibidores de proteasas y muchas de las lectinas vegetales resistentes a la proteólisis de las enzimas que inhiben (Azarkan et al., 2006, Teles et al., 2005, Vasconcelos \& Oliveira, 2004) y también muchos alergenos alimentarios (Moreno et al., 2005a). Todas estas proteínas resisten la digestión, conservando su estructura tridimensional, manteniendo por ende su funcionalidad. Así, se ha determinado que la estructura de estas proteínas se encuentra íntimamente relacionada a la función que cumplen en la defensa del embrión, ya sea dentro de un huevo (animales) o semillas (plantas). En este sentido se ha podido determinar que la OR cumple funciones antinutritivas/antidigestivas (Dreon et al., 2010) y llamativamente una función similar se puede también asignar a la PV2 sumada a una potencial función en la sensibilización del sistema inmune y como lectinas, según se describe en el capítulo 6.

En conclusión, la elevada estabilidad de PV2 le permitiría mantener su integridad y funcionalidad frente a las desafiantes condiciones del ambiente que los huevos deben soportar durante su desarrollo. Esto, sumado a la también elevada estabilidad estructural de OR, permitiría comenzar a interpretar el mecanismo de adaptación a nivel bioquímico. Es decir, estas estables perivitelinas proveerían de una inusual capacidad protectiva a los embriones, permitendo a estos moluscos llevar adelante la estrategia reproductiva de poner huevos tan expuestos a la insolación (estabilidad térmica) y a los depredadores (estabilidad frente al pH, resistencia a la proteólisis digestiva) (capítulo 6). 
CAPITULO 6

Funciones 


\section{CAPITULO 6: Funciones}

\subsection{Introducción}

La única función de las perivitelinas PV2 y OR descripta hasta el momento de comenzar este estudio era la típica de las proteínas de reserva, aportando una importante fuente de nutrientes durante la embriogénesis (Heras et al., 1998).

Los huevos de la mayoría de los animales poseen un alto valor nutricional y, debido a ello, están sujetos a intensa depredación (Pechenik, 1986, Kamler, 2005, Ricklefs, 1969, Christeller, 2005). Sin embargo, aunque los huevos de Pomacea canaliculata poseen grandes cantidades de polisacáridos y proteínas (Heras et al., 1998) y están muy expuestos a la depredación, debido a la estrategia de depositarlos en el medio aéreo sin espinas ni ningún tipo de ornamentación protectora, todos los animales que se encuentran compartiendo el mismo hábitat parecen ignorarlos. Sus depredadores se limitan a la "hormiga de fuego" Solenopsis geminata (Yusa, 2001) y Quantula striata ((Ng \& Tan, 2011).

Por otra parte, esta falta de depredadores coincide con la llamativa coloración rojiza de los huevos que se asumía que era una coloración aposemática (Heras et al., 2007), aunque no existía ninguna evidencia de la presencia de una defensa química en el huevo, salvo en una especie relacionada (Pomacea paludosa) donde existían estudios en condiciones de laboratorio, que sugerían que los huevos eran no palatables (Snyder \& Snyder, 1971). Si bien ésta podría también ser la defensa de los huevos de P. canaliculata, no sería suficiente para explicar la falta de depredadores, ya que son muchos los huevos con esta defensa que no obstante están bajo fuerte depredación, sugiriendo la existencia de al menos un componente tóxico.

En este capítulo se presentan los resultados de experimentos en los que se buscó identificar los compuestos defensivos del FPV. Se caracterizaron las posibles funciones de la perivitelina PV2; en particular se estudió su resistencia a 
la digestión por proteasas y se determinó que forma parte de un novedoso sistema de defensa en que ésta actuaría como neurotoxina ante potenciales depredadores.

\subsection{Efectos tóxicos de los componentes del huevo}

6.2.1 Extractos de huevos en adultos de la misma especie

En primer lugar se inocularon $300 \mu \mathrm{g}$ de fracción soluble de huevo en el pie de caracoles adultos de P. canaliculata para observar si poseía algún efecto tóxico contra adultos de su propia especie. Transcurridas las $96 \mathrm{~h}$ del ensayo no se evidenció letalidad ni ninguna alteración en los mismos.

\subsubsection{Extractos de huevos en ratones y renacuajos}

Se realizaron ensayos in vivo de la fracción soluble de huevo en dos modelos experimentales: ratones hembra Balb-C (Mus musculus) de 4 a 6 semanas de edad y renacuajos de rana toro (Lithobates catesbeianus) obtenidos en un criadero de los alrededores de la ciudad, que se mantuvieron durante un mínimo de tres días en acuarios para su aclimatación antes de su empleo en los bioensayos (ver fig. 6.1).

Figura 6.1: Modelos experimentales utilizados para los ensayos in vivo. ( $A$ y $B$ ) Renacuajos de rana toro; $(C)$ ratones Balb- $C$.
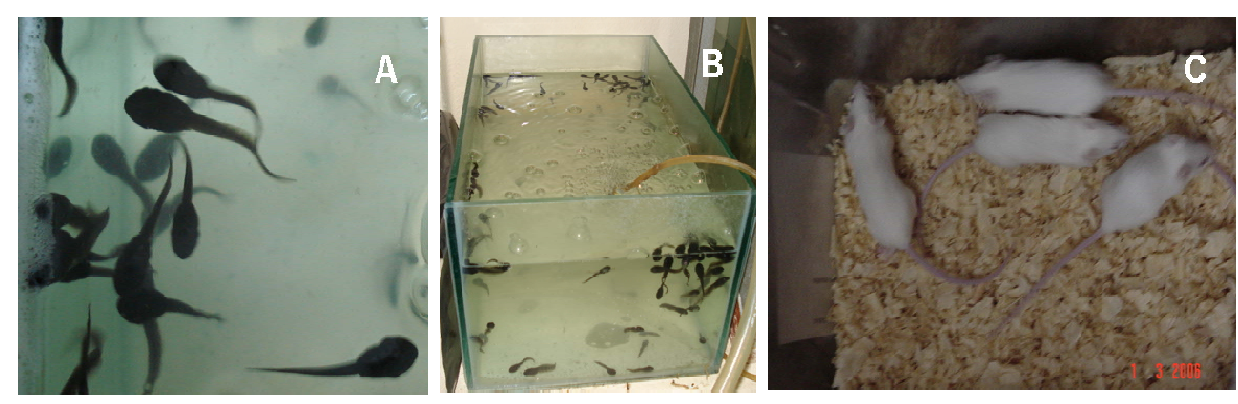
Al administrar los ratones por vía intraperitoneal (i.p.) la fracción soluble de huevos se observó en ellos, en pocas horas, sintomatología de intoxicación principalmente a nivel de las extremidades y posterior muerte de manera dosis dependiente. Se determinó entonces la dosis letal 50 (LD 50) a las 96 horas que fue de $2,3 \mathrm{mg} / \mathrm{kg}$.

Para los renacuajos la inyección se realizó por vía intramuscular (i.m.), entre el cuerpo y la cola, y si bien no pudo evidenciarse sintomatología dado el tipo de modelo, la fracción soluble resultó letal con una LD 50,96h de $21 \mathrm{mg} / \mathrm{kg}$.

\subsubsection{Identificación de la fracción tóxica: PV2}

En base a los resultados de toxicidad obtenidos en ratones y renacuajos, se prosiguió a identificar la fracción responsable de la actividad tóxica de los huevos, para lo cual, se purificaron las proteínas de la fracción soluble de huevo por cromatografía de intercambio iónico. Se obtuvieron tres fracciones proteicas (sección 3.1.3, fig. 3.2) identificadas como PV2, PV3 y OR (PV1).

Las tres fracciones fueron analizadas por separado mediante inoculación por vía i.p. en ratones Balb-C en una dosis de $6 \mathrm{mg} / \mathrm{kg}$, y sólo la fracción de la perivitelina PV2 presentó toxicidad.

Se analizó también la posible toxicidad de los extractos lipídicos extraídos de la fracción soluble de huevo (sección 3.7.2) que fueron inoculados en ratones vía i.p. pero no mostraron ningún tipo de afección, descartando la posibilidad que la toxina fuera de naturaleza lipídica.

\subsubsection{Caracterización de la actividad tóxica de PV2}

La purificación de la toxina PV2 se realizó por ultracentrifugación en gradiente de densidad seguida de dos pasos de cromatografía (ver detalles en la sección 3.1.3). La pureza y homogeneidad de la toxina se verificaron por geles de electroforesis. PV2 tiene una masa molecular de 400 kDa y dos subunidades de 31 y $67 \mathrm{kDa}$ como puede verse en la figura $6.2 \mathrm{~A}$ y $B$. 
Para descartar que la toxina fuera algún contaminante copurificado, se realizó un análisis mediante western blot (WB) utilizando anticuerpos primarios policlonales anti-PV2 realizados en conejo y su correspondiente anticuerpo secundario anti-IgG conjugado a peroxidasa (sección 3.4.1). Los resultados mostraron una fuerte reactividad con la PV2 (fig. 6.2.C).

Se determinó la LD 50,96h para PV2 purificada que fue de 0,25 mg/kg en ratones (vía i.p.) y $5,0 \mathrm{mg} / \mathrm{kg}$ en renacuajos (vía i.m.).

Figura 6.2: Electroforesis en gel nativo $(A)$, disociante $(B)$ y análisis por WB $(C)$ de la proteína tóxica. Grupo A: PAGGE 4-20\% p/v, Calle 1: estándar de alto peso molecular; 2: fracción soluble de huevo $(20 \mu \mathrm{g})$; 3: toxina purificada (3 $\mu$ g). Grupo B: SDS-PAGGE, Calle 1: estándar de bajo peso molecular; 2: proteína tóxica $(10 \mu g)$. Grupo $C$ : inmunotransferencia de proteína tóxica con anticuerpos anti-PV2 dilución 1:1000; Calle 1: estándar de peso molecular; 2: subunidades de proteína tóxica.
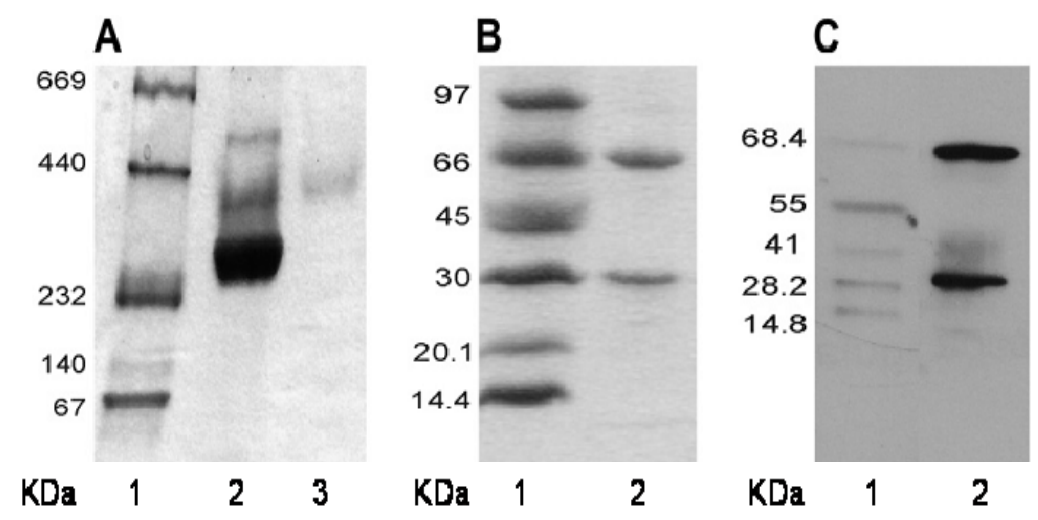

Una vez determinada la LD 50 de la toxina, se realizaron ensayos de susceptibilidad térmica por calentamiento a $100{ }^{\circ} \mathrm{C}$ y posterior inoculación en ratones. Se observó que a esta temperatura pierde su toxicidad, pero que la misma no disminuiría por congelación y descongelación sucesivas.

Por otra parte, los ratones que recibieron dosis subletales de la toxina y posteriormente dosis elevadas cercanas a la dosis letal 100 (LD100, 96h) no morían; aquí surgió la hipótesis que podrían haberse inmunizado al recibir sucesivas 
dosis subletales. Para comprobarlo, se inmunizaron ratones (ver sección 3.7.4) y se extrajeron sus sueros. Posteriormente realizamos un dot blot utilizando PV2 purificada como antígeno $(0,2 \mathrm{mg} / \mathrm{ml}$ de PBS), los sueros obtenidos como anticuerpo primario $\left(A 1^{\circ}\right)$ y su respectivo anticuerpo secundario $\left(A 2^{\circ}\right),($ fig. 6.3).

Figura 6.3: Dot blot de sueros de ratones inmunizados. A y B: suero control y suero de ratones inmunizados respectivamente como $A 1^{\circ}$, dilución 1:1000 y $A 2^{\circ}$ anti-IgG de ratón; $C$ : anticuerpo policlonal anti-PV2 diluido 1:2000 como $A 1^{\circ}$ y anti-IgG de conejo como $A 2^{\circ}$.

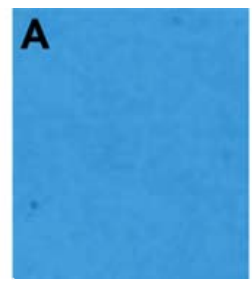

Centrel

negotive

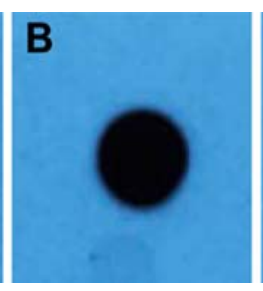

Raton Inmurizade

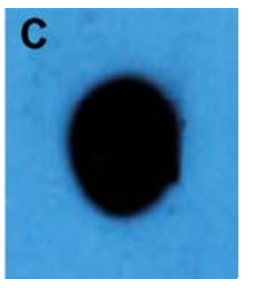

Centrol perttre

Como puede observarse en la figura 6.3, el ensayo de dot blot mostró que efectivamente los sueros de estos ratones presentaban una fuerte inmunorreactividad hacia el antígeno PV2, comprobando de esta manera que la toxina es inmunogénica.

\subsubsection{Sintomatología del modelo murino intoxicado}

Se inocularon ratones vía i.p. con una dosis letal de PV2 purificada (0.95 $\mu \mathrm{g} / \mathrm{g}$ ) registrando los síntomas. Pasadas las 16-20 h comenzaron a observarse signos clínicos, entre ellos: debilidad, letargo, cabeza baja y cuerpo encorvado, ojos semicerrados, taquipnea y pelo hirsuto. Además, presentaron abducción extrema de los miembros posteriores, paresia y no podían soportar su peso corporal (tetraplejía). Sin registro de reflejos anal, perineal, abdominal ni flexor, aunque conservaban parcialmente el reflejo plantar. Los músculos de la cola presentaban movimientos espásticos (tremores). 
A medida que la toxina continuó ejerciendo su efecto, pudieron verse alteraciones profundas de sensibilidad, posturas anormales, tambaleos, movimientos incoordinados en la marcha y carencia del tono muscular.

Pasadas las $30 \mathrm{~h}$ desde la inoculación, los ratones mostraron paraplejía fláccida con miembros posteriores completamente extendidos mientras que los anteriores seguían siendo funcionales. La muerte en la mayoría de los ratones ocurrió pasadas las 40 h. En dosis más altas (LD100, 96h) se produjo la muerte en menos de $30 \mathrm{~h}$.

\subsubsection{Efecto sobre diferentes órganos de ratón}

El examen microscópico de los órganos internos mostró normalidad en todos, excepto una leve hiperemia sin presencia de células inflamatorias en el útero, intestino y sistema nervioso.

En cuanto a la médula espinal, tanto con la tinción hematoxilina-eosina (HE) como con galocianina llamaron la atención las grandes neuronas motoras de la sustancia gris que presentaban cromatólisis (fig. 6.4).

Figura 6.4: Secciones transversales de médula espinal teñida con galocianina. $A$ y $C$ animales control B y D animales tratados con PV2. A, B: 10X; C, D: 40X.

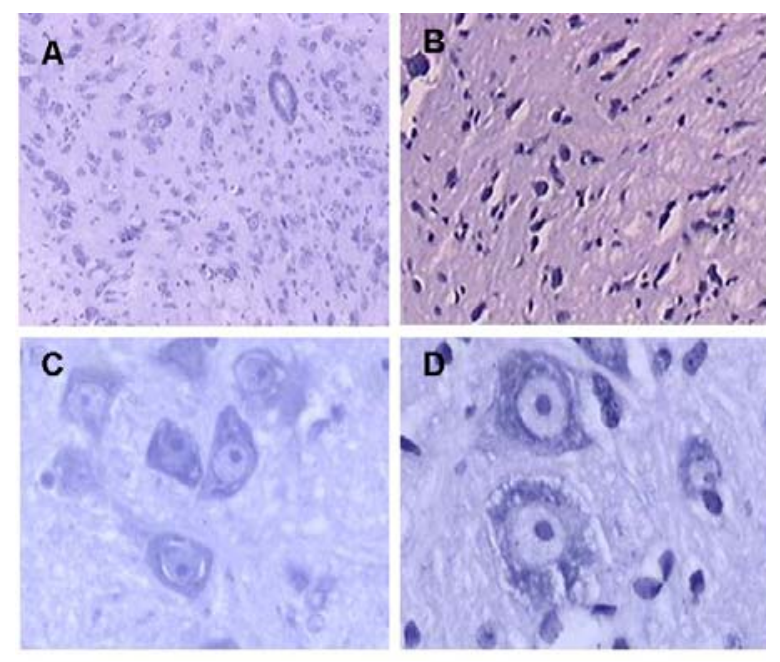


Las técnicas histológicas empleadas mostraron que la médula espinal era el único órgano blanco de la toxina, por lo que se decidió continuar trabajando con este órgano.

\subsubsection{Efecto sobre el SNC (metabolismo del calcio y apoptosis)}

Se analizó la médula en las regiones cervical, torácica y lumbar mediante inmunohistoquímica contra una proteína de unión al $\mathrm{Ca}^{+2}$ (calbindina). Pudieron apreciarse diferencias significativas en sus niveles de expresión entre los animales control y los inoculados a nivel del asta dorsal de la sustancia gris, región que contiene los elementos sensitivos de la médula.

En los controles observamos una inmunomarcación positiva muy notoria a calbindina a nivel de las láminas II y III según el modelo laminar propuesto por Rexed (1952) y por Paxinos y Watson (1986) en los tres niveles medulares analizados, mientras que en los animales inoculados la inmunomarcación fue negativa o presentó valores mínimos (fig. 6.5).

Los resultados cuali-cuantitativos se resumen en la tabla 6.1. Como puede observarse, el efecto más marcado en la región cervical.

No se evidenciaron diferencias significativas entre animales control y tratados con la toxina en la sustancia blanca.

Figura 6.5: Inmunolocalización de calbindina en astas dorsales de región cervical de médula espinal. $A$ y $C$ : Animales control; $B$ y D: Animales inoculados con PV2. Los núcleos fueron teñidos con $H E$. $A, B$ : 4x; C, D: $40 x$

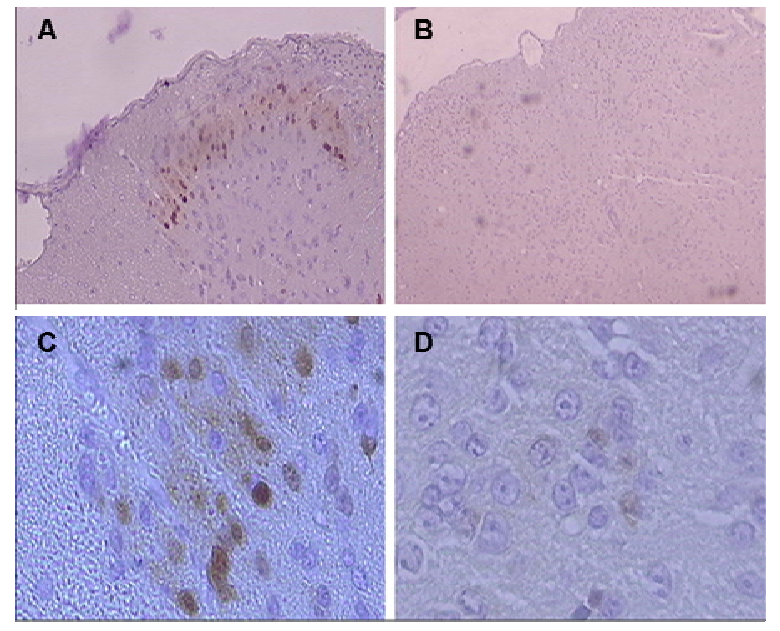


Tabla 6.1: Análisis cuali-cuantitativo de la inmunomarcación anti-calbindina a nivel del asta dorsal de la sustancia gris en sus segmentos medulares cervical, torácico y lumbar. Gradiente de intensidad creciente de inmunomarcación de (-) a 4 + (positivo).

\begin{tabular}{cccc} 
& Cervical & Toracico & Lumbar \\
\cline { 2 - 4 } Control & & & \\
\hline 1 & $4+$ & $3+$ & $3+$ \\
2 & $4+$ & $3+$ & $3+$ \\
3 & $4+$ & $2+$ & $3+$ \\
4 & $3+$ & $3+$ & $2+$ \\
Tratados & & & \\
\hline 1 & $3+$ & $-1+$ & $-1+$ \\
2 & $(-) 1+$ & $(-))^{++}$ & $2+$ \\
3 & $(-) 1+$ & $(-)$ & $(-)$ \\
4 & $3+$ & $(-) 1+$ & $(-)$ \\
5 & $(-)$ & $(-)$ & $(-)$ \\
6 & $(-)$ & $(-)$ & $(-)$ \\
\hline
\end{tabular}

Se analizó luego la presencia de apoptosis mediante el uso de la tinción de TUNEL, que reveló inmunotinción positiva de los animales inoculados con la toxina en el asta dorsal de la sustancia gris, pero sólo a nivel de las láminas II y III y en mayor medida a nivel de la región cervical (fig. 6.6.B). Esta localización fue coincidente con la falta de inmunotinción a calbindina en la misma posición laminar y en el mismo grupo celular.

Por otra parte, se observó inmunotinción negativa en las neuronas de la médula espinal de ratones control (fig. 6.6.A).

Figura 6.6: Tinción TUNEL. A: Animales control; B: Animales inoculados con PV2 $40 \mathrm{~h}$ post-inyección $(40 x)$.

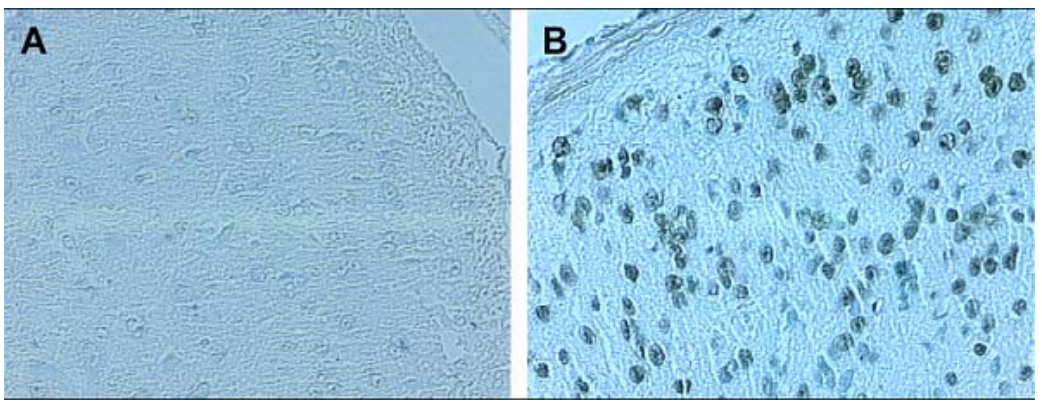




\subsubsection{Ensayos electrofisiológicos}

Los registros de la contracción del músculo sartorio de la rana Leptodactylus ocellatus indicaron que ni la fracción soluble de huevos ni sus proteínas purificadas (OR, PV2 y PV3) afectaron la actividad eléctrica de las fibras musculares ni los elementos contráctiles de los músculos. No se observa decaimiento de la fuerza de contracción (fig. 6.7).

Vale la pena señalar que los canales de $\mathrm{Na}^{+}$y $\mathrm{K}^{+}$en el músculo son similares a los presentes en las fibras nerviosas.

Figura 6.7: Registro de contracción de músculo sartorio. Frecuencia de contracción: 1/100 s, $1 \mathrm{~mm}=100 \mathrm{~s}$, calibración $10 \mathrm{~g}$

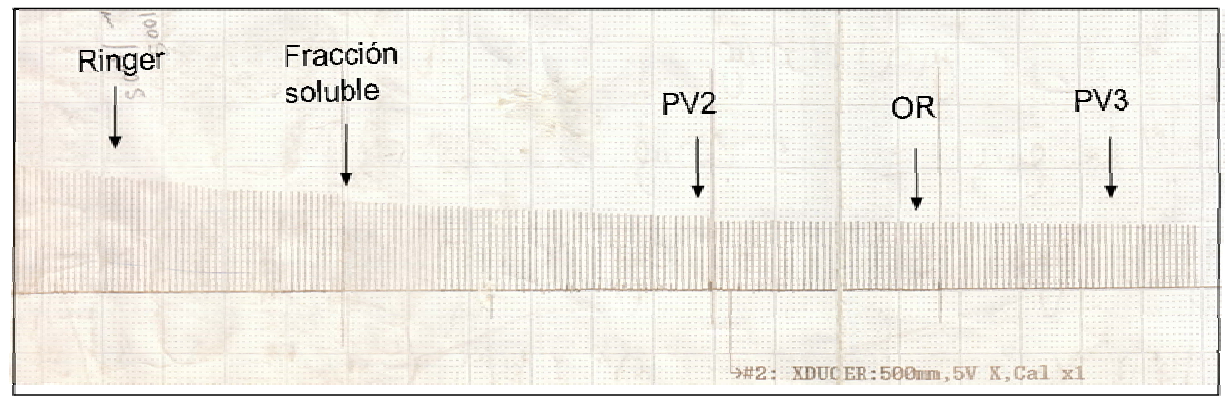

\subsection{Resistencia a la digestión gastrointestinal}

Para comprender la posibilidad de incorporación de la toxina al depredador que ingiera los huevos, se estudió la resistencia de la PV2 a la digestión, ya sea en estado nativo o desnaturalizado. Para ello utilizamos un modelo de digestión in vitro empleando las dos fases fisiológicamente adecuadas para simular el paso de los alimentos a través del estómago y duodeno, evaluando de esta manera la susceptibilidad de PV2 a la proteólisis.

\subsubsection{Digestión in vitro}

Se incubó la proteína en fluido gástrico simulado durante $2 \mathrm{~h}$ a $37^{\circ} \mathrm{C}$. Se observó mediante PAGGE que PV2 es resistente a la pepsinólisis tanto en 
condiciones nativas como disociantes (fig. 6.8). En todos los casos se utilizaron 10 $\mu \mathrm{g}$ de BSA con enzima como control positivo y BSA sin proteasa como control negativo.

Figura 6.8 : Geles de PV2 (10 $\mu$ g) expuesta a pepsina (pep). A: PAGGE; B: SDS-PAGGE con reductor de puentes disulfuro $\beta$-ME; C: SDS-PAGGE sin $\beta$-ME. Calle 4: estándar de peso molecular (kDa).

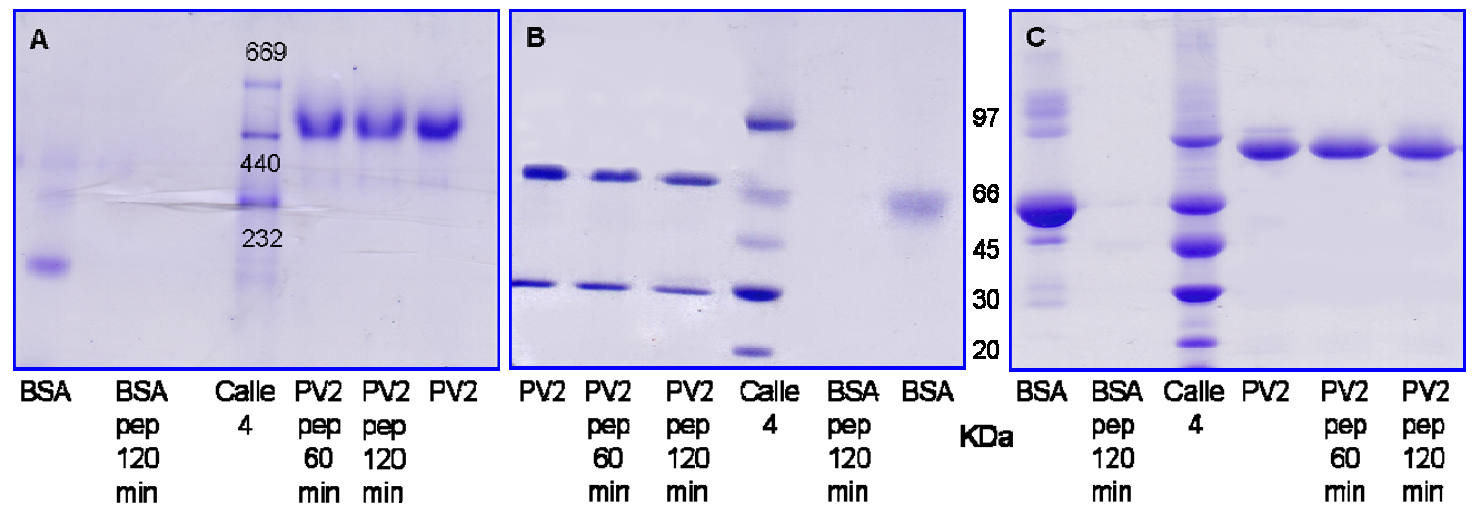

Una vez pasada la fase gástrica, se ajustó el pH de la solución a las condiciones del intestino (por encima de $\mathrm{pH} 7,0$ ) y se agregó la proteasa intestinal tripsina, incubándose nuevamente $a 37^{\circ} \mathrm{C}$ por otras $2 \mathrm{~h}$. Esta tripsinólisis tampoco mostró diferencias en los patrones de digestión con y sin la enzima (fig. 6.9).

Figura 6.9: PV2 en presencia de tripsina

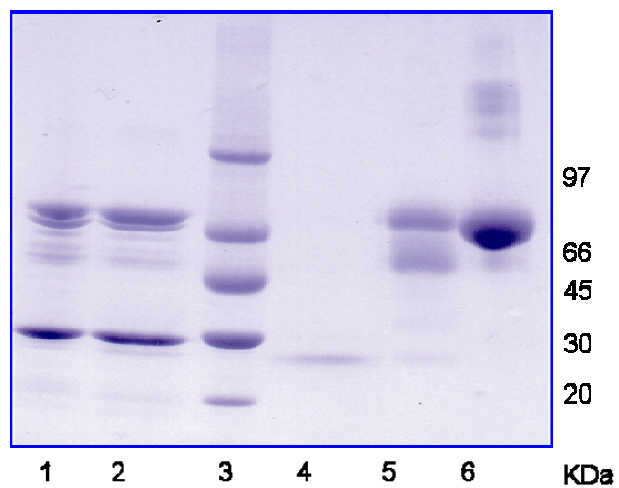

Leyenda: Calle 1: PV2 $10 \mu \mathrm{g}, 2:$ PV2 $10 \mu \mathrm{g}+$ tripsina $120 \mathrm{~min}$; 3:Estandar de peso molecular (KDa), 4: Tripsina control, 5: BSA + trisina $\uparrow 20 \mathrm{~min}, 6$ : BSA $10 \mu \mathrm{g}$ 
En síntesis, la incubación secuencial de PV2 con las proteasas digestivas pepsina y tripsina mostró que resiste la digestión gastrointestinal simulada sin sufrir cambios, al menos en su masa, que indiquen alteraciones estructurales importantes.

\subsubsection{Efecto de la administración oral a ratas}

Para evaluar si la administración oral de fracción soluble de huevos en ratas podía inmunizarlas, como ya habíamos podido observar por vía intraperitoneal en ratones (sección 6.2.4), se siguió un protocolo de inmunización oral (ver sección 3.4.1) y con los sueros se realizó un dot blot, utilizando como antígeno la fracción soluble en distintas diluciones.

El $A 1^{\circ}$ utilizado fue el suero de las ratas inoculadas diluido en PBST $1 \%$ $(1 / 100$ y $1 / 500)$ y el $A 2^{\circ}$, Anti-IgG de rata conjugado con peroxidasa (Sigma) en la dilución recomendada por el fabricante de 1/2500 en PBST $1 \%$.

En primer lugar se optimizaron las concentraciones del anticuerpo primario. En la figura 6.10 se observa que la condición de dilución $1 / 100$ de A $1^{\circ}$ mostró reactividad inespecífica semejante al suero control mientras que la dilución 1/500 mostró la mejor respuesta, por lo que esta dilución se empleó en los experimentos posteriores. También se ve que las ratas inoculadas muestran inmunorreactividad, evidenciando así que fueron inmunizadas por vía oral.

Figura 6.10: Dot blot de suero de ratas inoculadas vía oral con fracción soluble de huevos
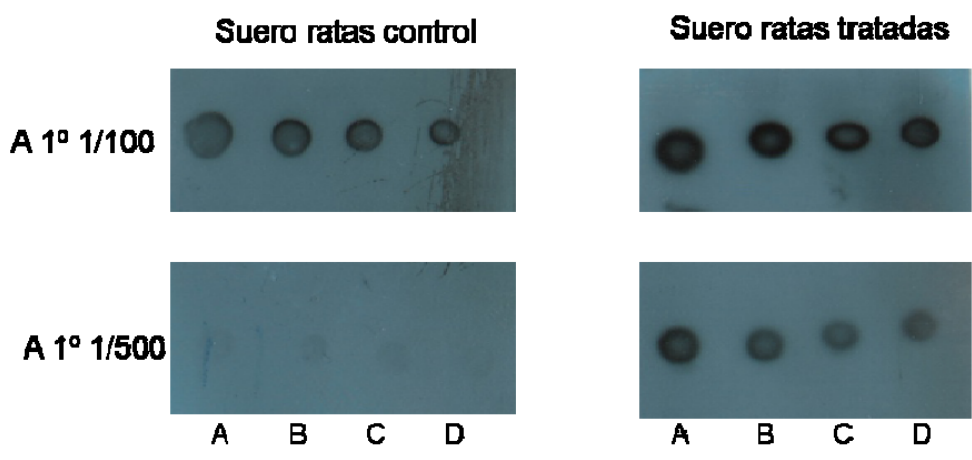

Leyenda: Antígeno Calle A: $30 \mu \mathrm{g}, \mathrm{B}: 15 \mu \mathrm{g}, \mathrm{C}: 7,5 \mu \mathrm{g}, \mathrm{D}: 3,5 \mu \mathrm{g}$ 
Para determinar si dicha inmunización era específica para alguna proteína de la fracción soluble en particular, se realizó un dot blot pero en este caso utilizando como antígenos OR y PV2 purificadas y las mismas condiciones de $A 1^{\circ} \mathrm{y}$ $2^{\circ}$. Como puede observarse en la figura 6.11 la inmunización oral sólo muestra reactividad frente a PV2.

Figura 6.11: Dot blot de OR y PV2

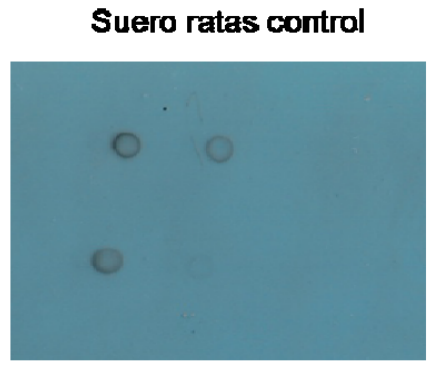

A $\quad$ B $\quad$ C $\quad$ D
Suero ratas tratadas

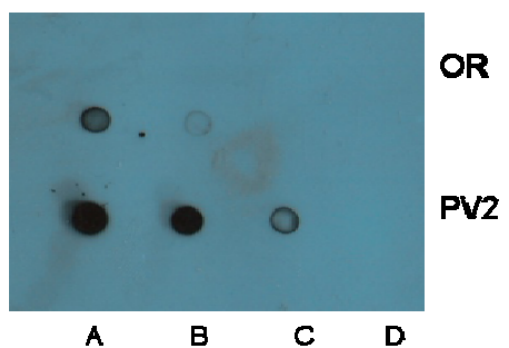

A $\quad$ B $\quad$ C $\quad$ D

Leyenda: Antígeno OR o PV2 A: 8 нg, B: dil 1/10, C: dil1/100, D: dil /1000

Por último realizamos un WB en condiciones disociantes utilizando PV2 como antígeno (ver leyenda de fig. 6.12) y con las diluciones de anticuerpos optimizadas anteriormente. Como puede apreciarse en la figura 6.12, la inmunización oral de ratas es notablemente específica hacia la subunidad mayor de la perivitelina PV2.

Figura 6.12: WB de suero de ratas inoculadas oralmente

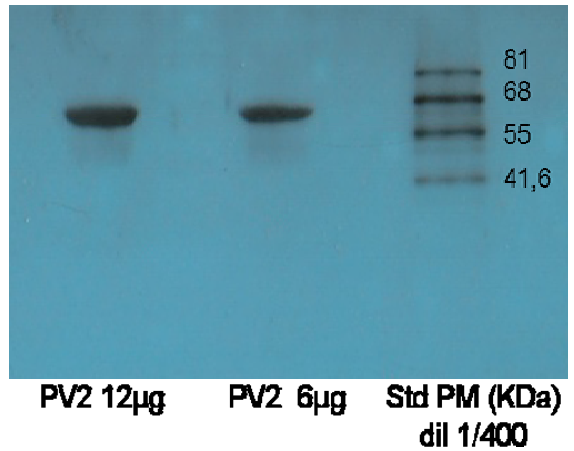

Std PM: estándar de peso molecular Chemiblot (Chemicon) 


\subsection{Discusión}

Las perivitelinas de huevos de gasterópodos son proteínas de reserva y poseen todas funciones nutritivas. No obstante, en los últimos años se identificaron en algunas de ellas, otras funciones como fotoprotectores, antimicrobianos, antineoplásicos, lectinas, inhibidores de proteasas o inclusive, como factores de crecimiento para el embrión en desarrollo (Benkendorff et al., 2001, Dreon et al., 2004, Iijima et al., 1995, Kamiya et al., 2006, Kisugi et al., 1989, Mukai et al., 2004, Nagle et al., 1999, 2001, Sanchez et al., 2006). En el presente trabajo se pudo demostrar que además pueden tener función neurotóxica.

Algunos animales pueden volverse tóxicos adquiriendo los compuestos tóxicos de sus alimentos y esto requiere la evolución previa de mecanismos que los hagan resistentes a la toxina. El secuestro y la acumulación de estas toxinas puede proporcionarles protección frente a los depredadores, que aprenden a evitar a estas presas recordando experiencias previas, siempre que adviertan la presencia llamativa y fácil de memorizar de la defensa. Dentro de estas sustancias se incluyen tanto compuestos tóxicos como con sabor desagradable (no palatables). Este es un fenómeno común tanto en animales marinos como terrestres (Mebs, 1998). Inclusive, estas toxinas pueden ser a veces transferidas a los huevos, acumulándose en concentraciones letales que protegen al embrión, algunas son potentes neurotoxinas de naturaleza no proteica (Miyazawa et al., 1987).

En este trabajo demostramos la presencia de una neurotoxina en los huevos de P. canaliculata que corresponde a la perivitelina PV2. La naturaleza proteica e identidad de la perivitelina previamente caracterizada se demostró de varias maneras. En primer lugar, los ratones que recibieron concentraciones elevadas de PV2 purificada murieron, aunque dosis subletales pudieron inmunizarlos tanto por vía intraperitoneal como por vía oral. Por otra parte, la toxicidad se inactiva a $100{ }^{\circ} \mathrm{C}$, característico de las toxinas de naturaleza proteica al desnaturalizarse (ver capítulo 5). 
En comparación con otras toxinas, PV2 se clasifica como "extremadamente tóxica", con una LD50, $96 \mathrm{~h}$ de $0,25 \mathrm{mg} / \mathrm{kg}$. Aunque no es tan potente como las conotoxinas de caracoles marinos, se encuentra en el mismo orden de toxicidad que las neurotoxinas de varias serpientes (Gawade, 2004).

No sabemos si los ratones intoxicados perciben el dolor (nocicepción), si bien no se observó retracción de las extremidades paralizadas cuando se estimularon con un elemento punzante. La toxina ejerce su neurotoxicidad aguda en ratones modificando la morfología del asta dorsal de la sustancia gris de la médula. Por otra parte, PV2 no afectó la actividad eléctrica ni los elementos contráctiles del músculo de la rana, lo que refuerza la acción específica sobre el sistema nervioso central sugerida también por el estudio histológico de todos los órganos.

El calcio desempeña un papel clave en la supervivencia neuronal, muerte celular programada (apoptosis) y degeneración neuronal patológica. Se sabe que alteraciones en la regulación del calcio pueden tener potenciales efectos letales (Bastianelli, 2003). La base molecular de la neurodegeneración en el sistema nervioso central se debe a un aumento de la concentración de calcio libre en el citosol (Ramirez-Exposito \& Martinez-Martos, 1998). Por lo tanto, la regulación de la expresión de proteínas que unen calcio es un factor crítico para los agentes que interrumpen la homeostasis de calcio en las neuronas (Bastianelli, 2003, Iacopino \& Christakos, 1990, Iacopino et al., 1990, Lema Tome et al., 2006, Mattson et al., 1991). Neuronas ricas en proteínas de unión de calcio, especialmente calbindina y parvalbumina, son relativamente más resistentes a la degeneración, trastornos agudos y crónicos (McMahon et al., 1998). En particular, la calbindina D-28K se expresa normalmente en poblaciones neuronales restringidas del cerebro de los mamíferos, donde cumple un papel crucial en la protección de las neuronas contra los daños excitotóxicas (Lee et al., 2004).

Teniendo en cuenta toda esta información, en una primera aproximación a la identificación del mecanismo de acción de la neurotoxina, se estudiaron algunos aspectos del metabolismo del calcio en la neurona. 
En primer lugar se observó que los animales intoxicados presentaban una significativa disminución de inmunomarcación de calbindina específicamente en las láminas II y III del asta dorsal superficial de la medula espinal. Si bien no hay trabajos en este sentido en ratones, hay estudios que muestran que las neuronas que contienen calbindina se marcan en las láminas II y III en las ratas (Yamamoto et al., 1989, Yoshida et al., 1990).

La apoptosis es un tipo de muerte celular programada que ocurre durante muchos procesos fisiológicos normales presentando características morfológicas como fragmentación de la cromatina que puede visualizarse por la técnica de TUNEL. La activación del programa de muerte celular se puede producir por muy diversas señales y en la transducción de estas señales está involucrado el ion calcio. En nuestro caso, la muerte celular apoptótica fue localizada en la misma población neuronal donde se registró la reducción de expresión de calbindina. Esto es coincidente con investigaciones que sugieren la participación de la calbindina como tampón de calcio evitando la apoptosis en células susceptibles del sistema nervioso central (Wernyj et al., 1999).

La disminución de niveles de calbindina se puede entonces considerar un indicador temprano de trastornos neurológicos inducidos por la toxicidad aguda de PV2. Por otra parte, una menor expresión de calbindina también se ha asociado con el envejecimiento del cerebro y en varios trastornos de neurodegeneración como la enfermedad de Parkinson, Alzheimer, la corea de Huntington, isquemia cerebral y epilepsia (Iacopino \& Christakos, 1990, Krzywkowski et al., 1995).

El hecho de que PV2 es una proteína oligomérica de gran tamaño, excluye cualquier daño por acción directa sobre la médula espinal debido a la baja permeabilidad de la barrera hematoencefálica a macromoléculas. Sin embargo, sus subunidades son lo suficientemente pequeñas como para penetrar sin inconvenientes la barrera por endocitosis (Poduslo et al., 1994). Además se ha demostrado que la glicosilación de las proteínas, como es el caso de PV2, aumentan su permeabilidad a través de la barrera (Poduslo \& Curran, 1994). 
Con el objeto de conocer si era posible que PV2 ingresara en una conformación activa al depredador, se diseñaron experimentos de digestión gastrointestinal simulada. En estos experimentos in vitro, PV2 mostró ser altamente resistente a la digestión por las proteasas pepsina y tripsina al igual que otras perivitelinas como la OR (Dreon et al., 2008, 2010) y escalarina (Ituarte, 2010). La especificidad de las enzimas proteolíticas, que permite que sólo hidrolice la unión peptídica de unos pocos aminoácidos, está fuertemente influenciada por la estructura primaria, secundaria o terciaria de la proteína a hidrolizar. En este sentido, las perivitelinas OR, escalarina y PV2 presentan elevada estabilidad estructural frente a un amplio rango de $\mathrm{pH} \sin$ sufrir alteraciones de su estructura nativa (Dreon et al., 2008, Ituarte, 2010, capítulo 5). Esto podría estar favorecido por la presencia de carbohidratos que otorgan a las glicoproteínas resistencia contra la proteólisis (Varki \& Lowe, 2009). También los enlaces disulfuro podrían contribuir a la estabilidad estructural y por ende disminuir el acceso a las secuencias de ataque proteolítico.

Tanto la OR como la PV2 transitarían conjuntamente el tracto digestivo de manera intacta y luego actuarían cumpliendo funciones diferentes, aunque parecen complementarse como parte de un mecanismo de defensa contra los depredadores.

Recientemente se comprobó que la acción de OR sería antinutritiva y antidigestiva (Dreon et al., 2010); esto contrasta con la hipótesis clásica que asume que los inhibidores de proteasas de huevos tienen función antimicrobiana en la cual se incluía originalmente a la OR (Norden, 1972).

La resistencia a la proteólisis gastrointestinal tiene muchas implicancias en el rol múltiple de PV2. Por un lado indica que la perivitelina sería indigestible y por lo tanto antinutritiva, una propiedad que comparte con la OR (Dreon et al., 2010) y, por otra parte, sugiere que la toxina mantendría su estructura nativa y por ende su actividad fisiológica al ser ingerida por posibles depredadores. Al llegar prácticamente intacta al intestino, dada su función lectina, podría sensibilizar la mucosa y generar respuesta del sistema inmunológico, un mecanismo muy estudiado en alergenos y proteínas alimenticias (Moreno et al., 2005a, Astwood et al., 1996); 
o bien cumplir funciones de defensa como toxina tal como ocurre con las lectinas vegetales altamente resistentes a la degradación por proteasas digestivas que provocan alteraciones en la fisiología digestiva (Carbonaro et al., 1997, Oliveira et al., 1994, Pusztai, 1991, Ríos et al., 1996, Vasconcelos \& Oliveira, 2004).

Si bien las funciones antinutritivas de OR son compartidas también por la PV2, esta última además ejercería su acción en el SNC, para la cual un paso obligado es atravesar la mucosa intestinal. Esto podría lograrse a través de las células $M$, componente de las placas de Peyer que funcionan como sitios efectores para el inicio de la inmunidad de las mucosas, probablemente el principal sitio de acción de los antígenos y los alergenos de los alimentos (Chambers et al., 2004, Nicoletti, 2000).

Las células M se caracterizan por presentar microvellosidades atrofiadas e irregulares, glicocálix y mucus escaso que facilitan el acceso de los antígenos luminales a su membrana apical y sin presentar actividad enzimática. Poseen pocos lisosomas y citoplasma deformado por la presencia de un bolsillo intraepitelial que alberga linfocitos $B, T$ CD4 y algunos macrófagos. Funcionalmente son capaces de asegurar el transporte rápido de macromoléculas e inclusive microorganismos hacia los tejidos linfoides subyacentes a través de vesículas con cubierta de clatrina (Penmimpete et al., 2004).

El tránsito celular es facilitado por una discontinuidad en la lámina basal justo debajo de las células $M$, característica explotada por ciertos virus (poliovirus y reovirus) y por bacterias como Salmonella sp. y Brucella sp. para invadir el organismo. Una vez liberados en la región subepitelial, los antígenos (en este caso la PV2) pueden interactuar con células del tejido linfoide subyacente e iniciar el desarrollo de una respuesta inmune local.

La inmunización oral con fracción soluble de huevos provocó una eficiente respuesta inmune desarrollando anticuerpos anti-PV2 en ratas. Dicha inmunización fue específica para PV2, en especial la subunidad mayor de dicha perivitelina, lo cual podría avalar la hipótesis, mencionada más arriba, de que las subunidades y no 
la proteína nativa sería/n las que atraviesan la barrera hematoencefálica para ejercer su acción neurotóxica en la médula.

En resumen, las hembras de P. canaliculata, producen metabólicamente las defensas químicas que contienen sus huevos (antidigestibilidad, toxicidad y eventual aposematismo), es decir que no provienen de la ingestión de tóxicos ni de presas pigmentadas. Las proteínas de defensa son al mismo tiempo proteínas de almacenamiento (perivitelinas) por lo que luego de ejercer su efecto protector, son finalmente consumidas durante el desarrollo de los embriones (Heras et al., 1998).

En este capítulo se reporta por primera vez en moluscos de agua dulce la función neurotóxica de la perivitelina PV2, aportando las primeras aproximaciones de su mecanismo de acción en el metabolismo de calcio neuronal y la presencia de anticuerpos circulantes luego de una administración oral de la toxina. La PV2 es la primera neurotoxina de naturaleza proteica descripta en huevos. 


\section{CAPITULO 7}

Dieta y esfuerzo reproductivo 


\section{CAPÍTULO 7: Efecto de la dieta y esfuerzo reproductivo sobre la toxicidad y calidad de los huevos}

\subsection{Introducción:}

Si bien Pomacea canaliculata es uno de los caracoles dulceacuícolas mejor estudiados de nuestro país, varios aspectos de sus estrategias reproductivas aún se desconocen.

El esfuerzo reproductivo, es decir la inversión energética que las hembras destinan a la reproducción, es muy elevado, ya que deposita una gran cantidad de puestas conformadas por varios cientos de huevos $(311 \pm 192$, con diferencias significativas dentro de una población), con una cubierta calcárea y dispuestos de manera compacta en una única masa de tamaño considerable (Albrecht et al., 1996, Estebenet \& Cazzaniga, 1993, Estoy et al., 2002a).

En Japón se observó que el número y la biomasa de puestas de $P$. canaliculata decrecen a lo largo de la vida reproductiva, mientras que el tamaño y viabilidad de los huevos no parecen variar ni ser afectados por la disponibilidad trófica (Estoy et al., 2002a). Por el contrario, en las poblaciones de la provincia de Buenos Aires se han detectado diferencias en el tamaño y peso de neonatos entre ambientes con distinta disponibilidad trófica (Martín \& Estebenet, 2002) que podrían deberse a la distinta composición de las reservas de los huevos.

En los moluscos, las reservas energéticas pueden estar constituidas por diferentes tipos de moléculas. Así, en bivalvos y cefalópodos se ha encontrado que los huevos acumulan altos niveles de proteínas y lípidos de reserva y una baja cantidad de hidratos de carbono (Gabbott, 1983, Heras \& Pollero, 1990, Holland, 1978, Sastry, 1979). Por el contrario, los gasterópodos almacenan principalmente hidratos de carbono (Goudsmit, 1972, Pandian, 1969). Estas reservas se encuentran ubicadas en el FPV que rodea al cigoto (Heras et al., 1998, 2007, JongBrink et al., 1983). En particular, en los huevos de Caenogastropoda 
(prosobranquios) y pulmonados, predomina el polisacárido galactógeno (Raven, 1972, Horstmann, 1956). En P. canaliculata el $98 \%$ de los hidratos de carbono del FPV (principalmente galactógeno) es absorbido por los embriones durante el desarrollo, particularmente en la organogénesis, siendo ésta la fuente energética más importante para hacer frente a la demanda catabólica (Heras et al., 1998). Por otra parte, las reservas de proteínas y lípidos presentes en el FPV (que forma las perivitelinas OR, PV2 y PV3) proporcionan los precursores estructurales durante la embriogénesis, si bien, también contribuyen parcialmente a la energía suministrada por los hidratos de carbono (Heras et al., 1998). No obstante esta función como proteínas de reserva, no se debe olvidar que las perivitelinas de P. canaliculata cumplen multiplicidad de importantes funciones antes de ser captadas por los embriones (capítulo 6; Dreon et al., 2004, 2010).

La disponibilidad trófica es un factor difícil de cuantificar en especies como $P$. canaliculata que es polífago y emplea una amplia variedad de recursos como alimento (Tamburi, 2009).

En el presente capítulo se estudian los huevos de sucesivas puestas, a lo largo de una estación reproductiva, utilizando hembras sometidas a diferente estado nutricional en condiciones controladas, con el objetivo de determinar si estas variables provocaban cambios en el tamaño, número de puestas, composición y calidad de sus reservas, así como analizar si alteraban su toxicidad y coloración. 


\subsection{Efecto sobre la coloración:}

El color de las puestas de huevo de los tratamientos Control (C) y media ración $(M)$ se determinó evaluando su reflectancia mediante espectroscopía (ver metodología, 3.9.1).

Los resultados de las medidas de reflectancia entre las distintas puestas de huevos pueden observarse en la figura 7.1. Como los datos no cumplen los supuestos establecidos para un test estadístico paramétrico, se realizó el test no paramétrico de Mann Whitney cuyos resultados muestran que la diferencia entre los dos tratamientos empleados no es significativa (fig. 7.1, tabla), así como tampoco se observaron diferencias a lo largo del tiempo.

Figura 7.1: Espectros típicos de la reflectancia obtenida para puestas de huevos de hembras tratadas bajo diferente régimen alimentario ( $C$ : ración completa y $M$ : ración media de alimento). La tabla muestra la reflectancia promedio de los tratamientos. Los números 1 al 9 corresponden a espectros de diferentes puestas mostrados a modo de ejemplo.

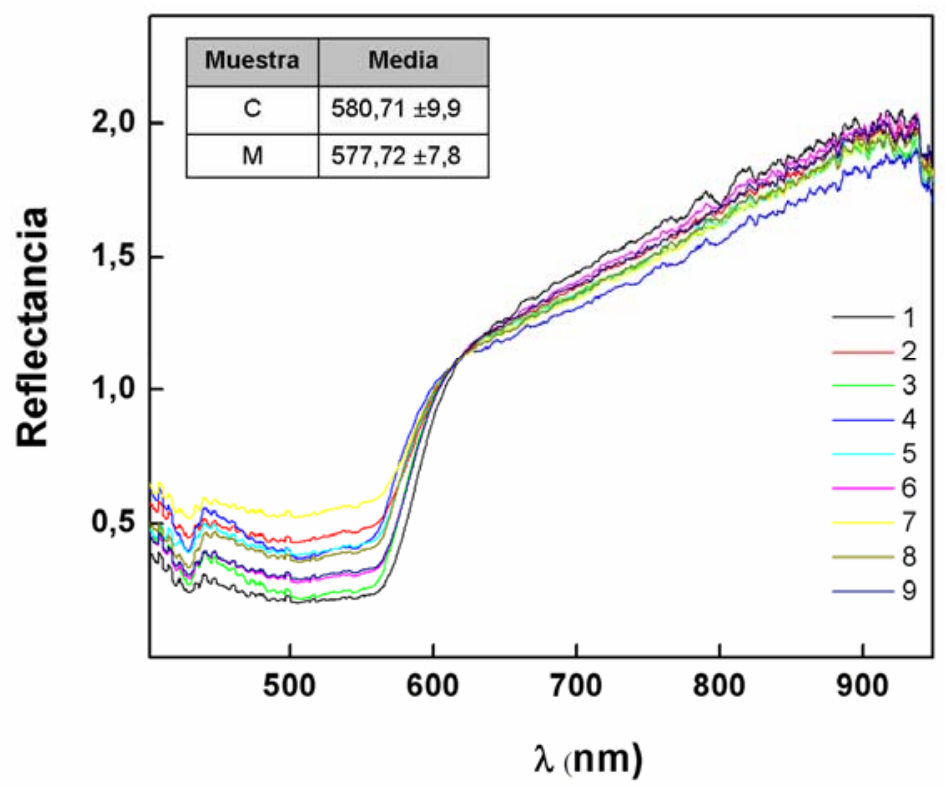




\subsection{Efecto sobre la cantidad y tamaño de puestas:}

La cantidad de puestas promedio por hembra a lo largo de toda una estación reproductiva fue de 12 puestas, independientemente de la cantidad de alimento administrada.

En la figura 7.2 se grafican los resultados correspondientes a sólo cinco hembras de cada tratamiento para mayor claridad, si bien el resultado fue similar para todo el universo estudiado.

Figura 7.2: Peso de puestas a lo largo de la estación reproductiva. A: Hembras con media ración de alimento $(M)$. B: Hembras alimentadas con ración completa $(C)$. Cada color corresponde a una hembra diferente. En los recuadros se registra el peso promedio de las respectivas puestas.
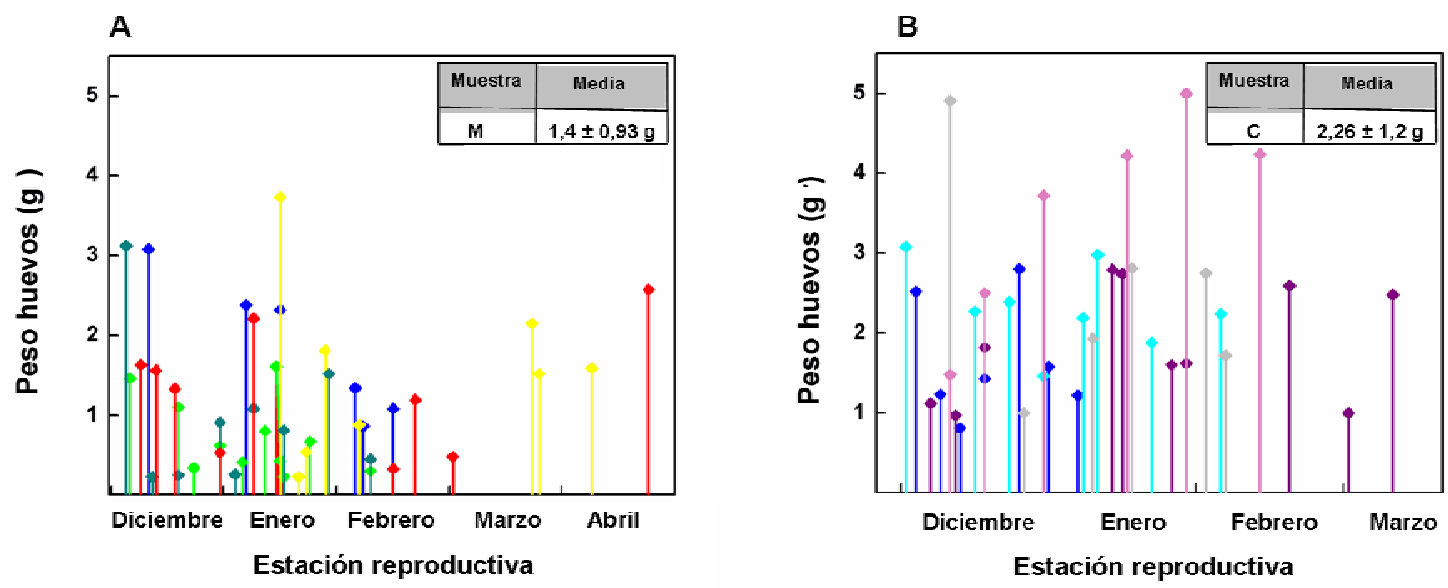

El peso promedio de las puestas de las hembras alimentadas con ración completa (fig. 7.2.B, recuadro) fue significativamente superior (test de Mann Whitney).

\subsection{Efecto sobre las defensas bioquímicas:}

Para evaluar la presencia de variaciones en el título de las perivitelinas mayoritarias (OR, PV2), se utilizó la técnica ELISA (ver detalles en el capítulo de metodología 3.4.4). 
En la figura 7.3 se ejemplifican los resultados obtenidos considerando sólo cinco hembras por tratamiento para mayor claridad.

Figura 7.3: Variación en el contenido de perivitelinas de los huevos a lo largo de toda la estación reproductiva. A: Huevos de hembras con media ración de alimento $(M)$. B: Huevos de hembras alimentadas con ración completa $(C)$. Cada color representa una hembra diferente. Valores expresados como \% del total de proteína del huevo.
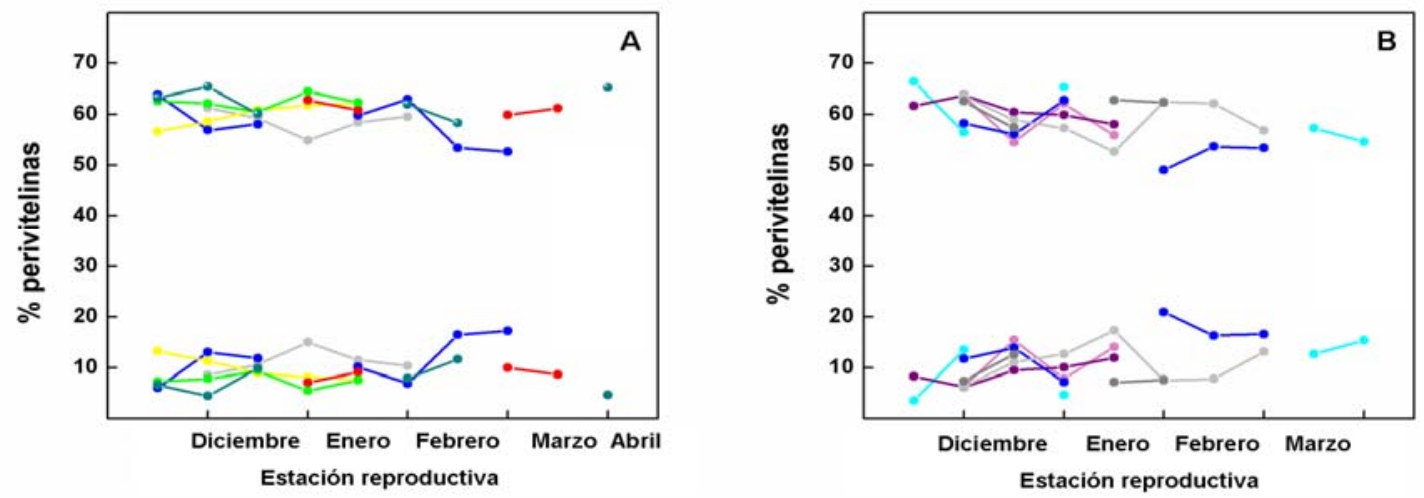

En la tabla 7.1 se muestran los valores porcentuales de las perivitelinas obtenidos para cada tratamiento, independientemente de la alimentación, éstos son cercanos al $60 \%$ para OR y $10 \%$ para PV2, sin existir diferencias estadísticas entre los tratamientos.

Tabla 7.1 Cantidad de perivitelinas (\%) para cada tratamiento trófico

\begin{tabular}{|c|c|c|}
\hline & Hembras C & Hembras M \\
\hline$\%$ OR & $58,9 \pm 5,3$ & $60,5 \pm 4,2$ \\
\hline$\%$ PV2 & $11,1 \pm 5,3$ & $9,5 \pm 4,2$ \\
\hline $\begin{array}{c}\text { Cantidad de puestas } \\
\text { analizadas }\end{array}$ & 70 & 61 \\
\hline
\end{tabular}




\subsection{Efecto sobre la energética del huevo:}

Por último, evaluamos si la principal reserva energética presente en los huevos, el galactógeno, presentaba variaciones en sucesivas puestas de hembras $C$ y $M$ (tabla 7.2.).

Tabla 7.2: Contenido de galactógeno de huevos de hembras bajo distintos régimenes alimenticios y sus valores promedio. Los subíndices " $p$ " y " $u$ " hacen referencia a la primera y última puesta respectivamente que la hembra en cuestión realizó en la estación reproductiva. Valores expresados como \% p. húmedo del huevo.

\begin{tabular}{|c|c|}
\hline Muestra & $\begin{array}{c}\text { \% Galactógeno } \\
\text { p/p }\end{array}$ \\
\hline M7 p & 5,1 \\
\hline M7 u & 6,9 \\
\hline M10 p & 10,8 \\
\hline M10 u & 10,2 \\
\hline M4 p & 3 \\
\hline M4 u & 3,3 \\
\hline M9 p & 3,3 \\
\hline M9 u & 2,7 \\
\hline M13 p & 4,5 \\
\hline M13 u & 27 \\
\hline
\end{tabular}

\begin{tabular}{|c|c|}
\hline Muestra & $\begin{array}{c}\text { \% Galactógeno } \\
\text { p/p }\end{array}$ \\
\hline $\mathrm{C} 7 \mathrm{p}$ & 8,7 \\
\hline $\mathrm{C} 7 \mathrm{u}$ & 11,7 \\
\hline $\mathrm{C} 10 \mathrm{p}$ & 6,6 \\
\hline $\mathrm{C} 10 \mathrm{u}$ & 9,6 \\
\hline $\mathrm{C} 8 \mathrm{p}$ & 5,1 \\
\hline $\mathrm{C} 8 \mathrm{u}$ & 6,6 \\
\hline $\mathrm{C} 13 \mathrm{p}$ & 4,2 \\
\hline $\mathrm{C} 13 \mathrm{u}$ & 3,3 \\
\hline $\mathrm{C} 3 \mathrm{p}$ & 4,5 \\
\hline $\mathrm{C} 3 \mathrm{u}$ & 6,9 \\
\hline
\end{tabular}

\begin{tabular}{|c|c|}
\hline Muestra & Media (p/p) \\
\hline C & $6,72 \pm 2,64 \%$ \\
\hline $\mathbf{M}$ & $5,25 \pm 3,0 \%$ \\
\hline
\end{tabular}

Las medias de ambos tratamientos no mostraron una diferencia significativa según un test de Student. Si bien se observa una tendencia en las hembras $C$ a aumentar la cantidad de galactógeno entre sus primeras y últimas puestas, esta no fue estadísticamente significativa. 


\subsection{Discusión:}

Durante la evolución de una especie surgen estrategias adaptativas de los ciclos vitales donde se llega a un compromiso costo-beneficio entre supervivencia y reproducción (Stearns, 1992). En otras palabras, el organismo puede utilizar la energía adquirida para funciones de crecimiento o bien para la reproducción y cuidados parentales.

El galactógeno aporta unas $142 \mathrm{cal} / 100 \mathrm{mg}$ huevo (p. seco), y es complementado por la captación y absorción diferencial de sus perivitelinas (Heras et al., 1998). Los resultados obtenidos en este capítulo mostraron que tanto los niveles de perivitelinas como de galactógeno se mantienen constantes en el huevo, independientemente del estado nutricional de la hembra, siendo similares a los reportados previamente para esta especie (Dreon et al., 2002, 2003, Heras et al., 1998). Teniendo en cuenta lo anterior, se puede inferir que la hembra aún frente al estrés generado por la deficiencia alimentaria, continúa invirtiendo su energía en la reproducción, probablemente en desmedro de otros aspectos de su biología.

En los juveniles recién nacidos, los remanentes de las perivitelinas se consumen en pocos días y posteriormente comienzan a alimentarse exclusivamente del entorno. El crecimiento continúa hasta adquirir una gran talla a la madurez. Se ha observado que durante esta etapa de maduración reproductiva, la disponibilidad trófica afecta varios parámetros del ciclo vital de $P$. canaliculata en forma diferente en machos y hembras (Estebenet \& Cazzaniga, 1992, 1993, Estebenet \& Martín, 2002, Martín \& Estebenet, 2002).

Las hembras maduran siempre a edades mayores que los machos, independientemente de la disponibilidad de alimento (Estoy et al., 2002b, Tamburi \& Martín, 2009). En síntesis en P. canaliculata aparentemente el tamaño corporal y la calidad del alimento son determinantes importantes de las eficiencias de conversión de alimento, no así la disponibilidad de alimento (Tamburi, 2009).

Los resultados obtenidos en el presente capítulo, a lo largo de toda una estación reproductiva, mostraron que ni la disponibilidad trófica ni las sucesivas 
puestas provocan cambios en el número de puestas así como tampoco en la calidad de los huevos, esta última estimada en términos de cantidad de reservas energéticas y sistema de defensa (perivitelinas tóxicas y coloración).

Observaciones previas a este experimento "a ojo desnudo" en el campo sugerían que las puestas no siempre se encontraban igualmente brillantes y coloreadas al principio y al fin de la estación reproductiva, pudiendo ser éste un indicio de que el contenido de toxinas de los huevos no fuera siempre igual. Darst et al. (2006) utilizaron la variación natural entre especies de ranas venenosas y demostraron que especies estrechamente relacionadas usan estrategias aposemáticas alternativas, combinando los componentes señal de elevada toxicidad con visibilidad moderada y toxicidad moderada con alta visibilidad. Ambas combinaciones tuvieron el mismo éxito para evitar a los depredadores y sugieren una solución de compromiso entre el color bien visible y en el logro de inapetencia. En nuestro caso, la cuantificación precisa de la reflectancia de las puestas de huevo, nos permitió descartar las evidencias casuales y determinar que, al menos en condiciones controladas de laboratorio, no existen cambios en la coloración. Esto estuvo de acuerdo con los datos de la concentración de defensas bioquímicas, que tampoco registraron variaciones a lo largo de una estación reproductiva, ya sea la mediada por la neurotoxina antinutritiva PV2 (capítulo 6) o por OR, de efectos antidigestivos y antinutritivos.

Es difícil realizar comparaciones de los cambios en las defensas con huevos de otros animales, ya que no existen estudios semejantes al de $P$. canaliculatay son pocos los estudios en los que se registraron variaciones en calidad y cantidad de toxinas. Entre ellos, se pueden mencionar la determinación de las variaciones a lo largo del desarrollo ontogenético en huevos de un anfibio y un cefalópodo. En Bufo marinus se observó que los huevos contienen las concentraciones más altas de toxinas, muchas de las cuales sólo se detectan en esta etapa ontogenética, luego la diversidad de toxinas disminuye durante la vida del renacuajo, pero vuelve a aumentar después de la metamorfosis. En el caso de los huevos de cefalópodos, en el pulpo Hapalochlaena sp. los niveles totales de la tetrodotoxina (TTX) aumentan 
durante el desarrollo y continúan incrementando sus niveles luego de la eclosión (Hayes et al., 2009, Williams et al., 2011). En el caso de P. canaliculata, el nivel de toxicidad del huevo va disminuyendo acorde se van consumiendo las perivitelinas a lo largo del desarrollo (Heras et al., 1998).

Por otra parte, estudiando las concentraciones de la neurotoxina TTX en huevos del tritón Taricha granulosa, se observó que existía amplia variación entre puestas diferentes aunque, al igual que en el caso de $P$. canaliculata, no se observó una correlación entre el tamaño de los huevos y los niveles de toxicidad (Hanifin et al., 2003).

En los huevos de P. canaliculata no se observaron diferencias en la calidad, sino exclusivamente cambios a nivel de los pesos de las puestas de huevos, donde la cantidad de huevos depositadas por hembras bien alimentadas fue mayor, lo cual es esperable dada la mayor cantidad de energía disponible para invertir en reproducción. Este resultado está de acuerdo con lo observado en poblaciones asiáticas de P. canaliculata por Estoy et al. (2002a), quienes también encontraron que el nivel de alimentación afectaba el peso de masas de huevos producidas diariamente y no vieron diferencias en la cantidad de puestas. Tamburi y Martín (2011), estudiando poblaciones de P. canaliculata argentinas, también observaron que hembras con restricciones en la disponibilidad trófica depositan un número semejante de puestas, pero con menos huevos por puesta. Por el contrario, Albrecht et al. (1999) encontraron que bajo condiciones de restricción del $25 \%$ de dieta normal, una restricción más marcada que la empleada en el presente estudio, lo que disminuye es la cantidad de puestas pero sin advertir diferencias en el tamaño de las puestas ni el volumen de los huevos. Asimismo, Tamburi (2009) observó una disminución de la cantidad de puestas si las hembras se sometían a un ayuno completo e instantáneo. En nuestro experimento, la disminución de ración de alimento del $50 \%$ no fue suficiente para provocar dichos cambios.

En resumen, en este caso en particular, el tamaño de los huevos se encuentra priorizado y la variable de ajuste es el número de huevos por puesta; manteniéndose invariable su color, así como el contenido de neurotoxina 
antinutritiva (PV2) y de su componente antinutritivo/antidigestivo (OR). Quizás el hecho de oviponer un mismo número de veces en ambos tratamientos pueda deberse a que aun con una disminución del 50 \% les toma el mismo tiempo recargar de perivitelo las glándulas del albumen y la cáscara (Tamburi, 2009). 


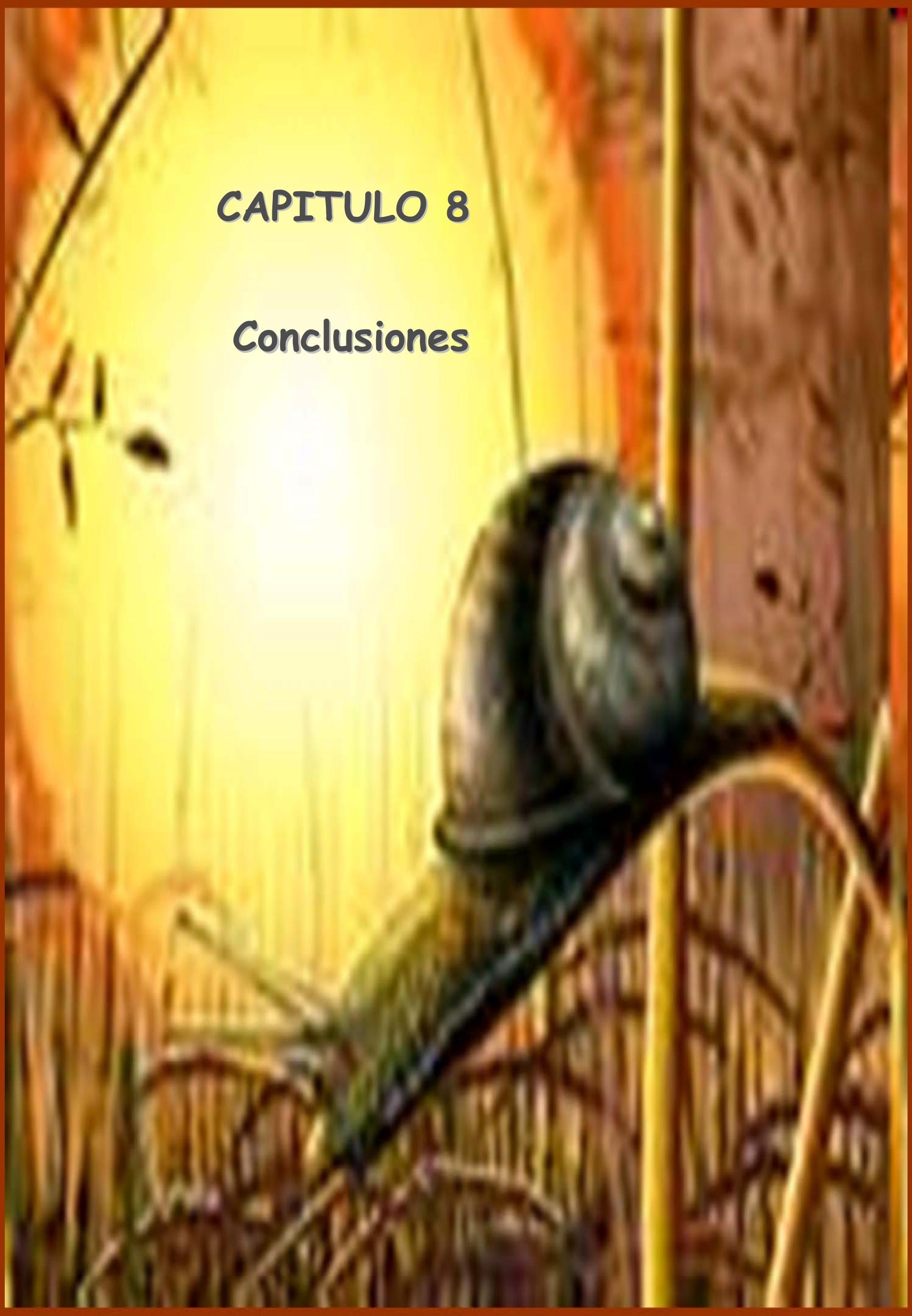




\section{CAPÍTULO 8: Conclusiones}

* Se caracterizó estructuralmente PV2, determinando por primera vez su estructura primaria parcial, secundaria, terciaria y cuaternaria.

* PV2 es un octámero compacto y bien plegado; sus subunidades se agrupan formando cuatro heterodímeros, cada uno estabilizado por puentes disulfuro intercatenarios. La subunidad mayor es la más susceptible a la proteólisis con proteinasa $K$ (inespecífica), lo que sugiere una disposición más hacia el exterior de la partícula en una región más expuesta a la digestión y/o menos compacta.

* La secuencia nucleotídica de la subunidad menor presentó homología con un tipo de lectinas llamado taquilectina con función en el sistema inmunológico innato y el desarrollo embrionario.

* Presenta estabilidad conformacional en un amplio rango de valores de pHy una elevada termoestabilidad mientras que es sensible a concentraciones moderadas de urea. Es además resistente a la digestión con las proteasas digestivas pepsina y tripsina presentes en el fluido gastrointestinal de vertebrados e invertebrados. Teniendo en cuenta estos resultados y los similares obtenidos para la ovorrubina, se postula que la PV2 también sería una partícula antinutritiva pero a diferencia de $O R$, es a la vez neurotóxica, ingresando al menos parte de la partícula en una conformación biológicamente activa a la circulación general del depredador.

La fracción soluble de huevos es tóxica para ratones por vía intraperitoneal (i.p) y para renacuajos por vía intramuscular (i.m). 
* Se identificó a PV2 como la única fracción tóxica de los huevos, con una letalidad alta sobre en ratones (vía i.p.) y moderadamente tóxica en renacuajos (i.m.). La toxina es inmunogénica tanto por vía oral como i.p. y la toxicidad del huevo es inactivada por calor.

La PV2 provoca neurotoxicidad aguda en ratones, modificando la morfología del asta dorsal superficial de la sustancia gris de la médula espinal, afectando la homeostasis del calcio y provocando muerte celular apoptótica en la población neuronal de las láminas II y III de dicha región. Esta toxicidad parecería ser mediada solo por la subunidad mayor que es capaz de ingresar por vía oral en ratas y generar anticuerpos circulantes.

* Ni la fracción soluble de huevos ni sus proteínas purificadas (OR, PV2 y PV3) afectaron la actividad eléctrica de las fibras musculares ni los elementos contráctiles de los músculos de la rana Leptodactylus ocellatus.

* Los niveles de toxicidad del huevo y la coloración asociada, con posible función de advertencia, no varían ni con el régimen alimentario, ni el esfuerzo reproductivo de las hembras. Sólo se registró una disminución en el número de huevos de las puestas depositadas por hembras con media ración de alimento, confirmando la alta plasticidad de su ciclo vital.

Propuesta de un modelo de acción de la PV2:

Integrando la evidencias obtenidas en el presente trabajo de tesis junto con los datos previos de la literatura sobre la ovorrubina, se propone un nuevo rol para las perivitelinas en las defensas frente a un depredador: La estabilidad estructural de PV2 en un amplio rango de $\mathrm{pH}$ y su resistencia a la proteólisis gastrointestinal, sugieren un mecanismo que tornaría a esta perivitelina antinutritiva o indigestible. Esto, sumado a que la ovorrubina también presenta 
esta propiedad, nos permite sugerir un mecanismo de defensa en el cual el depredador aprendería a reconocer y evitar estos huevos (coloración aposemática) que no le brindan ninguna nutrición. Al mismo tiempo, la estructura tan estable en el ambiente gastrointestinal, permitiría a la toxina mantener su actividad biológica en el intestino. Así, las propiedades de lectina de la subunidad menor, podrían permitirle sensibilizar la mucosa, generando respuesta del sistema inmunológico. La subunidad mayor ingresaría a la circulación de alguna manera aún no determinada, quizás vía células $M$ del intestino y sería presentada al sistema inmunitario. Por último la subunidad que es capaz de generar anticuerpos circulantes, atravesaría la barrera hematoencefálica para ejercer su acción neurotóxica en la médula.

Las hembras de $P$. canaliculata, no ingieren tóxicos ni presas pigmentadas que aporten las defensas bioquímicas de los huevos (antidigestibilidad, toxicidad y aposematismo) ya que, a diferencia de lo que está descrito para huevos de otros animales, todas estas defensas se encuentran codificadas en el genoma. Se podría especular entonces, que las perivitelinas de $P$. canaliculata tienen una importancia fisiológica clave en su biología reproductiva, ya que no solo proveen de nutrientes y energía al embrión sino que, actuando en forma conjunta y sinérgica, protegen los embriones, dotando a los huevos de múltiples defensas contra factores bióticos y abióticos. Este mecanismo adaptativo les permite hacer frente exitosamente a las duras condiciones ambientales y explicaría la virtual ausencia de depredadores. 


\section{CAPITULO 9}

Bibliografia 


\section{CAPÍTULO 9: Bibliografía}

Adams, M. E. \& Olivera, B. M. (1994). Neurotoxins: overview of an emerging research technology. Trends Neurosci. 17, 151-155.

Albrecht, E. A., Carreño, N. B., \& Castro-Vazquez, A. (1996). A quantitative study of copulation and spawning in the South American apple-snail, Pomacea canaliculata (Prosobranchia: Ampullariidae). Veliger 39, 142-147.

Albrecht, E. A., Carreño, N. B., \& Castro-Vazquez, A. (1999). A quantitative study of environmental factors influencing the seasonal onset of reproductive behaviour in the south American apple-snail Pomacea canaliculata (Gastropoda: Ampullariidae). J. Mollus. Stud. 65, 241-250.

Albrecht, E. A., Koch, E., Carreño, N. B., \& Castro-Vazquez, A. (2004). Control of the seasonal arrest of copulation and spawning in the apple snail Pomacea canaliculata (Prosobranchia: Ampullariidae): Differential effects of food availability, water temperature, and day length. Veliger 47, 169-174.

Alonso, D., Khalil, Z., Satkunanthan, N., \& Livett, B. G. (2003). Drugs from the sea: conotoxins as drug leads for neuropathic pain and other neurological conditions. Mini. Rev. Med. Chem. 3, 785-787.

Altschul, S. F., Madden, T. L., Schäffer, A. A., Zhang, J., Zhang, Z., Miller, W., \& Lipman, D. J. (1997). Gapped BLAST and PSI-BLAST: a new generation of protein database search programs . Nucleic Acids Res. 25, 33893402.

Alves García, V., Machado Freire, M. d. G., Novello, J. C., \& Rodrigues Macedo, M. L. (2004). Trypsin inhibitor from Poecilanthe parviflora seeds: purification, characterization, and activity against pest proteases. The Prot. J. 23, 343.

Andrade, M. A., Chacón, P., Merelo, J. J., \& Morán, F. (1993). Evaluation of secondary structure of proteins from UV circular dichroism using an unsupervised learning neural network. Prot. Eng. 6, 383-390. 
Astwood, J. D., Leach, J. N., \& Fuchs, R. L. (1996). Stability of food allergens to digestion in vitro. Nat. Biotechnol. 14, 1269-1273.

Avila, C. (2006) Subseries Marine molecular biotechnology molluscs from chemoecological study to biotechnological application, Chapter 1: Molluscan natural products as biological models: chemical ecology, histology, and laboratory culture, edited by G. Cimino \& M. Gavagnin, Berlin: Springer-Verlag.

Azarkan, M., Dibiani, R., Goormaghtigh, E., Raussens, V., \& Baeyens-Volant, D. (2006). The papaya Kunitz-type trypsin inhibitor is a highly stable b-sheet glycoprotein. Biochim. Biophys. Acta 1764, 1063-1072.

Bastianelli, E. (2003). Distribution of calcium-binding proteins in the cerebellum. Cerebellum. 2, 242-262.

Bendtsen, J. D., Nielsen, H., Van Heijne, G. \& Brunak, S. (2004). Improved prediction of signal peptides: SignalP 3.0. J. Mol. Biol. 340, 783-795.

Benkendorff, K., Davis, A. R., \& Bremner, J. B. (2001). Chemical Defense in the Egg Masses of Benthic Invertebrates: An Assessment of Antibacterial Activity in 39 Mollusks and 4 Polychaetes. J. Invert. Path. 78, 109-118.

Biermann, C., Schinner, G., \& Strathmann, R. (1992). Influence of solar radiation, microalgal fouling, and current on deposition site and survival of embryos of a dorid nudibranch gastropod. Mar. Ecol. Prog. Ser. 86, 205-215.

Bligh, E. G. \& Dyer, W. J. (1959). A rapid method of total lipid extraction and purification. Can. J. Biochem. Physiol. 37, 911-917.

Bouchet, P. \& Rocroi, J. P. (2005). Classification and nomenclator of gastropod families. Malacología 47, 1-397.

Bowersox, S. S. \& Luther, R. (1998). Pharmacotherapeutic potential of omegaconotoxin MVIIA (SNX-111), an N-type neuronal calcium channel blocker found in the venom of Conus magus. Toxicon 36, 1651-1658.

Brodie, E. D. (2002). Poisonous animals. New York: St. Marti's Press.

Burela, S. \& Martín, P. R. (2007). Nuptial feeding in the freshwater snail Pomacea canaliculata (Gastropoda: Ampullariidae). Malacología 49, 465-470. 
Carbonaro, M., Cappelloni, M., Nicoli, S., Lucarini, M., \& Carnovale, E. (1997). Solubility-digestibility relationship of legume proteins. J. Agri.c. Food Chem. 45, 3387-3394.

Carlsson, N. O. L., Brönmark C., \& Hansson, L. A. (2004a). Invading Herbivory: The golden apple snail alters ecosystem functioning in Asian wetlands. Ecology 85, 1575-1580.

Carlsson, N. O. L., Kestrup, A., Martensson, M., \& Nystrom, P. (2004b). Lethal and non-lethal effects of multiple indigenous predators on the invasive golden apple snail (Pomacea canaliculata). Freshwater Biol. 49, 1269-1279.

Catalán, N. M., Fernández, S. N., \& Winik, B. C. (2002). Oviductal structure and provision of egg envelops in the apple snail Pomacea canaliculata (Gastropoda, Prosobranchia, Ampullariidae). Biocell. 26, 91-100.

Catalán, M., Dreon, M. S., Heras, H., Pollero, R. J., Fernández, S. N., \& Winik, B. (2006). Pallial oviduct of Pomacea canaliculata (Gastropoda): ultrastructural studies of the parenchymal cellular types involved in the metabolism of perivitellins. Cell. Tissue Res. 324, 523-533.

Cazzaniga, N. J. (1981). Estudios bioecológicos de gasterópodos dulceaquícolas relacionados con la invación de canales por malezas acuáticas. Tesis doctoral. Universidad Nacional de La PLata, La Plata, Argentina.

Cazzaniga, N. (1990). Predation of Pomacea canaliculata (Ampullariidae) on adult Biomphalaria peregrina (Planorbidae). Annals. Trop. Med. and Parasit., 84, 97-100.

Cazzaniga, N. J. \& Estebenet, A. L. (1984). Revisión y notas sobre los hábitos alimentarios de los Ampullariidae (Gastropoda). Hist. Nat. 4, 213-224.

Chambers, S. J., Wickham, M. S. J., Regoli, M., Bertelli, E., Gunning, P. A., \& Nicoletti, C. (2004). Rapid in vivo transport of proteins from digested allergen across pre-sensitized gut . Biochem. Biophys. Res. Commun. 325, 12581263.

Cheesman, D. F. (1958). Ovorubin, a chromoprotein from the eggs of the gastropod mollusk Pomacea canaliculata. Proc. R. Soc. Lond. [Biol.] 149, 571-587.

Chen, S. C., Yen, C. H., Yeh, M. S., Huang, C. J., \& Liu, T. Y. (2001). Biochemical properties and $C D N a$ cloning of two new lectins from the plasma of 
Tachypleus tridentatus: Tachypleus plasma lectin 1 and 2. J. Biol. Chem. 276, 96319639.

Christeller, J. T. (2005). Evolutionary mechanisms acting on proteinase inhibitor variability. FEBS J. 272, 5710-5722.

Chye, M. L., Sin, S. F., Xu, Z. F., \& Yeung, E. C. (2006). Serine proteinase inhibitor proteins: Exogenous and endogenous functions. In Vitro Cell. Dev. Biol. Plant 42, 100-108.

Ciminiello, P. \& Fattoruso, E. (2006). Subseries Marine Molecular Biotechnology. Molluscs From Chemo-ecological Study to Biotechnological Application, edited by G. Cimino \& M. Gavagnin, Berlin: Springer-Verlag.

Cowie, R. H. (2002). Molluscs as Crop Pests, edited by G. M. Baker, pp. 145-192. Wallingford: $C A B I$.

Cuezzo, M. G. (2009). Macroinvertebrados bentónicos sudamericanos. Sistemática y biología. editado por E. Domínguez \& H. R. Fernández, pp. 595-629. San Miguel de Tucumán: Fundación Miguel Lillo.

D'Orbigny, A. (1846). Voyage a l'Arnerique Meridionale. Tomo 5, parte 3, pp 365-379.

Darst, C. R., Cummings, M. E., \& Cannatella, D. C. (2006). A mechanism for diversity in warning signals: conspicuousness versus toxicity in poison frogs. Proc. Natl. Acad. Sci. USA 103, 5852-5857.

Dellisanti, C. D., Spinelli, S., Cambillau, C., Findlay, J. B. C., Zagalsky, P. F., Finet, S., \& Receveur-Brechot, V. (2003). Quaternary structure of alphacrustacyanin from lobster as seen by small-angle $X$-ray scattering. FEBS Lett. 544, 189-193.

Dreon, M. S., Lavarias, S., Garín, C. F., Heras, H., \& Pollero, R. J. (2002). Synthesis, distribution, and levels of an egg lipoprotein from the apple snail Pomacea canaliculata (Mollusca: Gastropoda). J. Exp. Zool. 292, 323-330.

Dreon, M. S., Heras, H., \& Pollero, R. J. (2003). Metabolism of ovorubin, the major egg lipoprotein from the apple snail. Mol. Cell Biochem. 243, 9-14. 
Dreon, M. S., Heras, H., \& Pollero, R. J. (2004a). Characterization of the major egg glycolipoproteins from the perivitellin fluid of the apple snail Pomacea canaliculata. Mol. Reprod. Dev. 68, 359-364.

Dreon, M. S., Schinella, G., Heras, H., \& Pollero, R. J. (2004b). Antioxidant defense system in the apple snail eggs, the role of ovorubin. Arch. Biochem. Biophys. 422, 1-8.

Dreon, M. S., Heras, H., \& Pollero, R. J. (2006). Biochemical composition, tissue origin and functional properties of egg perivitellins from Pomacea canaliculata. Biocell 30, 359-365.

Dreon, M. S., Ceolín, M., \& Heras, H. (2007). Astaxanthin binding and structural stability of the apple snail carotenoprotein ovorubin. Arch. Biochem. Biophys. 460, 107-112.

Dreon, M. S., Ituarte, S., Ceolin, M., \& Heras, H. (2008). Global shape and $\mathrm{pH}$ stability of ovorubin, an oligomeric protein from the eggs of Pomacea canaliculata. FEBS J. 275, 4530.

Dreon, M. S., Ituarte, S., \& Heras, H. (2010). The Role of the Proteinase Inhibitor Ovorubin in Apple Snail Eggs Resembles Plant Embryo Defense against Predation. PLoS One 5, e15059, doi:10.1371/journal.pone.0015059 [doi].

Eftink, M. R. (1991). Fluorescence Spectroscopy, Vol. 2, Principles, 2 ed. New York: Plenum Press.

Engwall, E. \& Perlmann, P. (1972). Enzyme-linked immunosorbent assay, ELISA III. Quantitation of specific antibodies by enzyme-labelled anti-immunoglobulin in antigen-coated-tubes. J. Immunol. 109, 129-135.

Estebenet, A. L. (1995). Food and feeding in Pomacea canaliculata (Gastropoda: Ampullariidae). Veliger 38, 277-283.

Estebenet, A. L. (1998). Allometric growth and insight on sexual dimorphism in Pomacea canaliculata (Gastropoda: Ampullariidae). Malacologia 39, 207-213.

Estebenet, A. L. \& Cazzaniga, N. J. (1992). Growth and demography of Pomacea canaliculata (Gastropoda: Ampullariidae) under laboratory conditions. Malacological Review 25, 1-12. 
Estebenet, A. L. \& Cazzaniga, N. J. (1993). Egg variability and the reproductive strategy of Pomacea canaliculata (Gastropoda: Ampullariidae). APEX 8, 129-138.

Estebenet, A. L. \& Cazzaniga, N. J. (1998). Sex-related differential growth in Pomacea canaliculata (Gastropoda: Ampullariidae). Journal of Molluscan Studies, 64, 119-123.

Estebenet, A. L. \& Martín, P. R. (2002). Pomacea canaliculata (Gastropoda: Ampullariidae): life-history traits and their plasticity. Biocell 26, 83-89.

Estebenet, A. L., Martín, P. R., \& Burela, S. (2006). Conchological variation in Pomacea canaliculata and other South American Ampullariidae (Caenogastropoda, Architaenioglossa). Biocell 30, 329-335.

Estoy, J., Yusa, Y., Wada, T., Sakurai, H., \& Tsuchida, K. (2002a). Effects of food availability and age on the reproductive effort of the apple snail, Pomacea canaliculata (Lamarck) (Gastropoda: Ampullariidae). Appl. Entomol. Zool. 37, 543550.

Estoy, J., Yusa, Y., Wada, T., Sakurai, H., \& Tsuchida, K. (2002b). Size and age at first copulation and spawning of the apple snail, Pomacea canaliculata (Gastropoda: Ampullariidae). Appl. Entomol. Zool. 37, 199-205.

Favreau, P., Le Gall, F., Benoit, E., \& Molgo, J. (1999). A review on conotoxins targeting ion channels and acetylcholine receptors of the vertebrate neuromuscular junction. Acta Physiol. Pharmacol. Ther. Latinoam. 49, 257-267.

Frank, I. M. \& Vavilov, S. L. (1931). Über die Wirkungssphäre der auslöschuns-fargänge in den fluoreszierenden Flussigkeiten. Zeitschrift für Physik 69, 100-110.

Freifelder, D. (2003). Técnicas de Bioquímica y Biología Molecular. Serie de Biología Fundamental. Editorial Reverté, S.A.

Gabbott, P. A. (1983). The Mollusca, Vol 2, Chapter 5: Developmental and Seasonal Metabolic activities in marine molluscs edited by P. W. Hochachka, pp. 165-217. New York: Academic Press.

Galliano, M., Minchiotti, L., Campagnoli, M., Sala, A., Visai, L., Amoresano, A., Pucci, P., Casbarra, A., Cauci, M., Perduca, M., \& Monaco, H. L. 
(2003). Structural and biochemical characterization of a new type of lectin isolated from carp eggs. Biochem. J. 376, 433-440.

Garin, C. F.. Heras, H., \& Pollero, R. J. (1996). Lipoproteins of the egg perivitellin fluid of Pomacea canaliculata snails (Mollusca: Gastropoda). J. Exp. Zool. 276, 307-314.

Gawade, S. P. (2004). Snake venom neurotoxins: Pharmacological classification. J. toxicol. Toxin reviews 23, 37-96.

Gorg, A., Drews, O., Luck, C., Weiland, F., \& Weiss, W. (2009). 2-DE with IPGs. Electrophoresis 30 Supp/ 1, S122-S132, doi:10.1002/elps.200900051 [doi].

Goudsmit, E. M. (1972). Carbohydrates and carbohydrate metabolism in mollusca, Chemical Zoology ed. New York: Academic Press.

Hammersley, A. P. (1997). Fit2D. An Introduction and overview, Grenoble, France: European Synchrotron Radiation Facility, ESRF97HAO2T.

Hanifin, C. T., Brodie, E. D., III, \& Brodie, E. D., Jr. (2003). Tetrodotoxin levels in eggs of the rough-skin newt, Taricha granulosa, are correlated with female toxicity. J Chem. Ecol. 29, 1729-1739.

Hayat, M. A. (1986). Basic techniques for transmission electron microscopy. London: Academic Press.

Hayes, K. A., Joshi, R. C., Thiengo, S. C., \& Cowie, R. H. (2008). Out of South America: Multiple origins of non-native apple snails in Asia. Diversity and Distributions 14, 701-712.

Hayes, K. A., Cowie, R. H., \& Thiengo, S. C. (2009a). A global phylogeny of apple snails: Gondwanan origin, generic relationships, and the influence of outgroup choice (Caenogastropoda: Ampullariidae). Biol. J. Linn. Soc. 98, 61-76.

Hayes, R. A., Crossland, M. R., Hagman, M., Capon, R. J., \& Shine, R. (2009b). Ontogenetic variation in the chemical defenses of cane toads (Bufo marinus): toxin profiles and effects on predators. J. Chem. Ecol. 35, 391-399, doi:10.1007/s10886-009-9608-6 [doi].

Heras, H. \& Pollero, R. J. (1990). Occurrence of plasma lipoproteins in octopods. Partial characterization and interorgan transport of lipids. J. Exp. Mar. Biol. Ecol. 140, 29-38. 
Heras, H., Garín, C. F., \& Pollero, R. J. (1998). Biochemical composition and energy sources during embryo development and in early juveniles of the snail Pomacea canaliculata (Mollusca: Gastropoda). J. Exp. Zool. 280, 375-383.

Heras, H., Dreon, M. S., Ituarte, S., \& Pollero, R. J. (2007). Egg carotenoproteins in neotropical Ampullariidae (Gastropoda: Arquitaenioglossa). Comp. Biochem. Physiol. C 146, 158-167.

Hoffmann, J. A., Kafatos, F. C., Janeway, J. C. A., \& Ezenowitz, R. A. B. (1999). Phylogenetic perspectives in innate immunity. Science 284, 1313-1318.

Holland, D. L. (1978). Biochemical and Biophysical Perspectives in Marine Biology 4 ed., edited by D. C. Malins \& J. R. Sargent, pp. 85-123.

Horstmann, H. J. (1956). Der galaktogengehalt der eier von Lymnaea stagnalis wabrend der embryonalentwicklung . Biochem. Z. 328, 342-347.

Huang, X. \& Miller, W. (1991). LALIGN version 2.0. Adv. Appl. Math. 12, 373381.

Huh, C. G., Aldrich, J., Mottahedeh, J., Kwon, H., Johnson, C., \& Marsh, R. (1998). Cloning and characterization of Physarum polycephalum tectonins. Homologues of limulus lectin L6. J. Biol. Chem. 273, 6565-6574.

Iacopino, A. M. \& Christakos, S. (1990). Specific reduction of calcium-binding protein (28-kilodalton calbindin-D) gene expression in aging and neurodegenerative diseases. Proc. Natl. Acad. Sci. USA 87, 4078-4082.

Iacopino, A. M., Rhoten, W. B., \& Christakos, S. (1990). Calcium binding protein (calbindin-D28k) gene expression in the developing and aging mouse cerebellum. Brain Res Mol. Brain Res. 8, 283-290.

Iijima, R., Kisugi, J., \& Yamazaki, M. (1995). Antifungal activity of aplysianin E, a cytotoxic protein of sea hare (Aplysia kurodal) eggs. Dev. Comp. Immunol. 19, 13-19.

Inoue, H., Nojima, H., \& Okayama, H. (1990). High efficiency transformation of Escherichia coli with plasmids. Gene 96, 23-28.

Ituarte, S., Dreon, M. S., Pollero, R. J., \& Heras, H. (2008). Isolation and partial characterization of a new lipo-glyco-carotenoprotein from Pomacea scalaris (Gastropoda: Ampullariidae). Mol. Reprod. Dev. 75, 1441-1448. 
Ituarte, S. (2010). Estudio estructural y funcional de perivitelinas de Pomacea canaliculata (Lamarck, 1822) y P. scalaris (d'Orbigny, 1835) (Architaenioglossa, Ampullariidae). Tesis doctoral, Universidad de La Plata, La Plata, Argentina.

Ituarte, S., Dreon, M. S., Pasquevich, M. Y., Fernandez, P. E., \& Heras, H. (2010). Carbohydrates and glycoforms of the major egg perivitellins from Pomacea apple snails (Architaenioglossa: Ampullariidae). Comp. Biochem. Physiol. B 157, 66-72, doi:S1096-4959(10)00125-9 [pii];10.1016/j.cbpb.2010.05.004 [doi].

Iwanaga, S., Kawabata, S., \& Muta, T. (1998). New types of clotting factors and defense molecules found in horseshoe crab hemolymph: their structure and functions. J. Biochem. (Tokyo) 123, 1-15.

Jaenicke, R. (1996a). How do proteins acquire their three-dimensional structure and stability? Naturwissenschaften 83, 544-554.

Jaenicke, R. (1996b). Stability and folding of ultrastable proteins: eye lens crystallins and enzymes from thermophiles. FASEB J. 10, 84-92.

Jaenicke, R. (2000). Stability and stabilization of globular proteins in solution. $J$. Biotechnol. 79, 193-203.

Jong-Brink, M., Boer, H. H., \& Joosse, J. (1983). Reproductive Biology of invertebrates Vol. 1. Oogenesis oviposition and oosorption, edited by K. G. Adiyodi \& R. G. Adiyodi, pp. 297-355. New York: John Wiley \& Sons.

Kamiya, H., Sakai, R., \& Jimbo, M. (2006). Subseries Marine Molecular Biotechnology. Molluscs From Chemo-ecological Study to Biotechnological Application, edited by G. Cimino \& M. Gavagnin, Berlin: Springer-Verlag.

Kamler, E. (2005). Parent-egg ontogeny Relationships in Teleost Fishes: An Energetics Perspective. Rev. Fish Biol. Fisheries 15, 399-421.

Kawabata, S. \& Iwanaga, S. (1999). Role of lectins in the innate immunity of horseshoe crab. Dev. Comp. Immunol. 23, 391-400.

Kawashima, Y., Nagashima, Y., \& Shiomi, K. (2002). Toxicity and tetramine contents of salivary glands from carnivorous gastropods. Shokuhin Eiseigaku Zasshi 43, 385-388. 
Kawashima, Y., Nagai, H., Ishida, M., Nagashima, Y., \& Shiomi, K. (2003). Primary structure of echotoxin 2, an actinoporin-like hemolytic toxin from the salivary gland of the marine gastropod Monoplex echo. Toxicon 42, 491-497.

Kisugi, J., Yamazaki, M., Ishii, Y.., Tansho, S., Muramoto, K., \& Kamiya, H. (1989). Purification of a novel cytolytic protein from the albumen gland of the sea hare, Dolabella auricularia. Chem. Pharm. Bull. 37, 2773-2776.

Knocker, M. \& Dol, I. (1992). Effects of noise in derivative spectrophotometry: anomalous bias arising from amplitude measurements. Analyst. 117, 1385-1397.

Kosower, E. M. \& Kosower, N. S. (1995). Bromobimane probes for thiols. Methods Enzymol. 251, 133-148.

Krzywkowski, P., De Bilbao, F., Senut, M. C., \& Lamour, Y. (1995). Agerelated changes in parvalbumin- and GABA-immunoreactive cells in the rat septum. Neurobiol. Aging 16, 29-40.

Kushlan, J. A. (1978). Predation on Apple Snail Eggs (Pomacea). Nautilus 92, 5758.

Laemmli, U. K. (1970). Cleavage of structural proteins during the assembly of the head of bacteriophage T4. Nature 227, 680-685.

Lakowicz, J. R. (1999). Principles of fluorescence spectroscopy, 2 ed. New York: Kluwer Academic/Plenum Publishers.

Lee, B. H., Lee, K. H., Kim, U. J., Yoon, D. H., Sohn, J. H., Choi, S. S., Yi, I. G. \& Park, Y. G. (2004). Injury in the spinal cord may produce cell death in the brain. Brain Res. 1020, 37-44.

Lema Tome, C. M., Bauer, C., Nottingham, C., Smith, C., Blackstone, K., Brown, L., Hlavaty, C., Nelson, C., Daker, R., Sola, R., Miller, R., Bryan, R., \& Turner, C. P. (2006). MK801-induced caspase-3 in the postnatal brain: inverse relationship with calcium binding proteins. Neuroscience 141, 1351-1363.

Lowe, S., Browne, M., Boudjelas, S., \& De Poorter, M. (2004). 100 of the World's Worst Invasive Alien Species A selection from the Global Invasive Species Database. Auckland, NZ.

Lowry, O. H., Rosenbrough, N. J., Farr, A. L., \& Randall, R. (1951). Protein measurement with the Folin phenol reagent. J. Biol. Chem. 193, 265-275. 
Lv, S., Zhang, Y., Liu, H. X., Hu, L., Yang, K., Steinmann, P., Chen, Z., Wang, L. Y., Utzinger, J., \& Zhou, X. N. (2009). Invasive Snails and an Emerging Infectious Disease: Results from the First National Survey on Angiostrongylus cantonensis in China. PLoS. Negl. Trop. Dis. 3, e368.

Mali, B., Soza-Ried, J., Frohme, M., \& Frank, U. (2006). Structural but not functional conservation of an immune molecule: $A$ tachylectin-like gene in Hydractinia. Dev. Comp. Immunol. 30, 275-281.

Manzi, A. E. \& Esko, J. D. (1995). Current Protocols in Molecular Biology p. 17.9.1-17.9.11. John Wiley \& Sons, Inc.

Martín, P. R. \& Estebenet, A. L. (2002). Interpopulation variation in lifehistory traits of Pomacea canaliculata (Gastropoda: Ampullariidae) in southwestern Buenos Aires Province, Argentina. Malacologia 44, 153-163.

Martín, P. R., Estebenet, A. L., \& Cazzaniga, N. J. (2001). Factors affecting the distribution of Pomacea canaliculata (Gastropoda: Ampullariidae) along its southernmost natural limit. Malacologia 43, 13-23.

Mattson, M. P., Rychlik, B., Chu, C., \& Christakos, S. (1991). Evidence for calcium-reducing and excito-protective roles for the calcium-binding protein calbindin-D28k in cultured hippocampal neurons. Neuron 6, 41-51.

McMahon, A., Wong, B. S., Iacopino, A. M., Ng, M. C., Chi, S., \& German, D. C. (1998). Calbindin-D28k buffers intracellular calcium and promotes resistance to degeneration in PC12 cells. Brain Res. Mol. Brain Res. 54, 56-63.

Mebs, D. (1998). Occurrence and sequestration of toxins in food chains. Toxicon $36,1519-1522$.

Melo, V. M., Duarte, A. B., Carvalho, A. F., Siebra, E. A., \& Vasconcelos, I. M. (2000). Purification of a novel antibacterial and haemagglutinating protein from the purple gland of the sea hare, Aplysia dactylomela rang, 1828. Toxicon 38, 1415-1427.

Merril, C. (1990). Methods in Enzimology. Academic Press, New York ed., Vol. 183, edited by $H$. Deutscher, pp. 477-487. 
Milward-De-Andrade, R., Carvalho, O. D., \& Guimaraes (1978). Bioecological data of Pomacea haustrum (Reeve, 1856), predator-competitor of intermediate hosts of Schistosoma mansoni Sambon 1907. Saude Publica 12, 78-89.

Miyazawa, K., Jeon, J. K., Noguchi, T., Ito, K., \& Hashimoto, K. (1987). Distribution of tetrodotoxin in the tissues of the flatworm Planocera multitentaculata (Platyhelminthes). Toxicon 25, 975-980.

Mochida, O. (1991). Spread of Freshwater Pomacea Snails (Pilidae, Mollusca) from Argentina to Asia. Micronesica 3, 51-62.

Moreno, F. J., Maldonado, B. M., Wellner, N., \& Mills, E. N. (2005a). Thermostability and in vitro digestibility of a purified major allergen $2 S$ albumin (Ses i 1) from white sesame seeds (Sesamum indicum L.). Biochim. Biophys. Acta $1752,142-153$.

Moreno, F. J., Mellon, F. A., Wickham, M. S., Bottrill, A. R., \& Mills, E. N. (2005b). Stability of the major allergen Brazil nut 25 albumin (Ber e 1) to physiologically relevant in vitro gastrointestinal digestion. FEBS J. 272, 341-352.

Mukai, S. T., Hoque, T., Morishita, F., \& Saleuddin, A. S. (2004). Cloning and characterization of a candidate nutritive glycoprotein from the albumen gland of the freshwater snail, Helisoma duryi (Mollusca: Pulmonata). Invert. Biol. 123, 83-92.

Nagai, T., Kawabata, S., Shishikura, F., \& Sugita, H. (1999). Purification, characterization, and amino acid sequence of an embryonic lectin in perivitelline fluid of the horseshoe crab. J. Biol. Chem. 274, 37673-37678.

Nagle, G. T., Akalal, D. B. G., \& Painter, S. D. (1999). Maternal impact on egg development in Lymnaea stagnalis. A growth factor is produced by the albumen gland in the reproductive tract. Invert. Reprod. Dev. 36, 171-174.

Nagle, G. T., de Jong-Brink, M., Painter, S. D., \& Li, K. W. (2001). Structure, localization and potential role of a novel molluscan trypsin inhibitor in Lymnaea. Eur. J. Biochem. 268, 1213-1221.

National Research Council (1996). Guide for the Care and Use of Laboratory Animals. Washington, USA: Academic Press. 
Naylor, R. (1996). Invasions in agriculture: Assessing the cost of the golden apple snail in Asia. AMBIO 25, 443-448.

Ng, T. \& Tan, S. (2011). Observations of land snails feeding on the eggs of Pomacea canaliculata (Lamarck, 1822) (Mollusca: Gastropoda). Nature in Singapore, 4, 79-83.

Nicoletti, C. (2000). Unsolved mysteries of intestinal M cells. Gut 47, 735-739.

Norden, D. A. (1972). The inhibition of trypsin and some other proteases by ovorubin, a protein from the eggs of Pomacea canaliculata. Comp. Biochem. Physiol. B 42, 569-576.

Oliveira, J. T. A., Vasconcelos, I. M., Gondim, M. J. L., Cavada, B. S., Moreira, R. A., Santos, C. F., \& Moreira L.I.M (1994). Canavalia brasiliensis seeds. Protein quality and nutritional implications of dietary lectin. J. Science of Food and Agricul. 64, 417-424.

Pahkala, M., Rasanen, K., Laurila, A., Johanson, U., Bjorn, L. O., \& Merila, $J$. (2002). Lethal and sublethal effects of UV-B/pH synergism on common frog embryos . Cons. Biol. 16, 1063-1073.

Pandian, T. J. (1969). Yolk utilization in the gastropod Crepidula fornicata. Mar. Biol. 3, 117-121.

Paxinos, G. \& Watson, C. (1986). The Rat Brain in stereotaxic coordinates 2nd ed., Sydney: Academic Press.

Pechenik, J. A. (1986). The encapsulation of eggs and embryos by Molluscs: An overview. Am. Malacol. Bull. 4, 165-172.

Penmimpete, E. F. F., Gómez, C. M., \& Stanchi, N. C. (2004). Introducción a la inmunología, Edulp ed.

Pizani, N. V., Estebenet, A. L., \& Martín, P. R. (2005). Effects of submersion and aerial exposure on clutches and hatchlings of Pomacea canaliculata (Gastropoda: Ampullariidae). Am. Malacol. Bull. 20, 55-63.

Poduslo, J. F. \& Curran, G. L. (1994). Glycation increases the permeability of proteins across the blood-nerve and blood-brain barriers. Brain Res. Mol. Brain Res. 23, 157-162. 
Poduslo, J. F., Curran, G. L., \& Berg, C. T. (1994). Macromolecular permeability across the blood-nerve and blood-brain barriers. Proc. Natl. Acad. Sci. USA 91, 5705-5709.

Pointier, J. P. \& Jourdane, J. (2000). Biological control of the snail hosts of schistosomiasis in areas of low transmission: the example of the Caribbean area. Acta Tropica 77, 53-60.

Press, W. H., Flannery, B. P., Teukolsky, S. A., \& Vetterling, W. T. (1988). Numerical Recipes: the art of scientific computing. Cambridge, USA. Cambridge University Press.

Provencher, S. W. \& Glockner, J. (1981). Estimation of globular protein secondary structure from circular dichroism. Biochemistry 20, 33-37.

Przeslawski, R. (2005). Combined effects of solar radiation and desiccation on the mortality and development of encapsulated embryos of rocky shore gastropods. Mar. Ecol. Prog. Ser. 298, 169-177.

Przeslawski, R., Davis, A. R., \& Benkendorff, K. (2004). Effects of ultraviolet radiation and visible light on the development of encapsulated molluscan embryos. Mar. Ecol. Prog. Ser. 268, 151-160.

Pusztai, A. (1991). Plant Lectins. Cambridge University Press.

Ramirez-Exposito, M. J. \& Martinez-Martos, J. M. (1998). The molecular basis of neurodegenerative processes in the central nervous system. Rev. Neurol. 26, 91-100.

Raven, C. P. (1972). Chemical Zoology. Academic Press, New York, London ed., edited by M. Florkin \& B. T. Scheer, pp. 155-185. New York: Academic Press.

Rawlings, T. A., Hayes, K. A., Cowie, R. H., \& Collins, T. M. (2007). The identity, distribution, and impacts of non-native apple snails in the continental United States. BMC. Evol. Biol. 7, 97.

Rexed, B. (1952). The cytoarchitectonic organization of the spinal cord in the cat. J. Comp. Neurol. 96, 415-496.

Ricklefs, R. (1969). An analysis of nesting mortality in birds. Smithsonian Contr. Zool. 9, 1-48. 
Rini, J. M. \& Lobsanov, Y. D. (1999). New animal lectin structures. Curr. Opin. Struct. Biol. 9, 578-584.

Ríos, F. J. B., Cavada, B. S., Medeiros, D. A., Moreira, R. A., Vasconcelos, I. M., \& Oliveira, J. T. A. (1996). Lectins: Biology, Biochemistry 11 ed., edited by E. R. P. B. S. B.-H. T. C. Van Driessche, pp. 277-284.

Rudd, P. M., Elliot, T., Cresswell, P., Wilson, I. A., \& Dwek, R. A. (2001). Glycosylation and the immune system. Science 291, 2370-2376.

Ruxton, G. D., Sherratt, T. N., \& Speed, M. P. (2004). Avoiding Attack: The Evolutionary Ecology of Crypsis, Aposematism, and Mimicry. Oxford, U.K: Oxford Univ. Press.

Saito, T., Kawabata, S., Hirata, M., \& Iwanaga, S. (1995). A novel type of Limulus lectin-L6. Purification, primary structure, and antibacterial activity. $J$. Biol. Chem. 270, 14493-14499.

Sambrook, J., Fritsch, E. F., \& Maniatis, T. (1989). Molecular cloning: a laboratory manual, $3^{\text {rd }}$ edition ed. New York: Cold Spring Harbor Press.

Sanchez, J. F., Lescar, J., Chazalet, V., Audfray, A., Gagnon, J., Alvarez, R., Breton, C., Imberty, A., \& Mitchell, E. P. (2006). Biochemical and structural analysis of Helix pomatia agglutinin. A hexameric lectin with a novel fold. J. Biol. Chem. 281, 20171-20180.

Sastry, A. N. (1979). Reproduction of marine Invertebrates. Vol III, edited by A. C. Giese \& J. S. Pearse, pp. 113-292. New York: Academic Press.

Schroder, H. C., Ushijima, H., Krasko, A., Gamulin, V., Thakur, N. L., ehlSeifert, B., Muller, I. M., \& Muller, W. E. (2003). Emergence and disappearance of an immune molecule, an antimicrobial lectin, in basal metazoa. $A$ tachylectin-related protein in the sponge Suberites domuncula. J. Biol. Chem. 278, 32810-32817.

Sembrook \& Russell (2001). Molecular cloning and laboratory Manual. New York.

Shiomi, K., Mizukami, M., Shimakura, K., \& Nagashima, Y. (1994). Toxins in the salivary gland of some marine carnivorous gastropods. Comp. Biochem. Physiol. $107 B, 427-432$. 
Shiomi, K., Kawashima, Y., Mizukami, M., \& Nagashima, Y. (2002). Properties of proteinaceous toxins in the salivary gland of the marine gastropod (Monoplex echo). Toxicon 40, 563-571.

Slom, T. \& Johnson, S. (2003). Eosinophilic Meningitis. Curr. Infect. Dis. Rep. 5, 322-328.

Slom, T. J., Cortese, M. M., Gerber, S. I., Jones, R. C., Holtz, T. H., Lopez, A. S., Zambrano, C. H., Sufit, R. L., Sakolvaree, Y., Chaicumpa, W.. Herwaldt, B. L., \& Johnson, S. (2002). An outbreak of eosinophilic meningitis caused by Angiostrongylus cantonensis in travelers returning from the Caribbean. N. Engl. J. Med. 346, 668-675, doi:10.1056/NEJMoa012462 [doi];346/9/668 [pii].

Snyder, N. F. R. \& Snyder, H. A. (1971). Defenses of the Florida apple snail Pomacea paludosa. Behaviour 40,175-215.

Stearns, S. C. (1992). The evolution of life histories. Oxford University Press pp 248

Svergun, D. I. (1992). GNOM 4.5. J. Appl. Cryst. 25, 495-503.

Svergun, D. I. (1999). Restoring low resolution structure of biological macromolecules from solution scattering using simulated annealing. Biophys. J.. 76, 2879-2886.

Svergun, D. I. \& Koch, M. H. J. (2003). Small-angle scattering studies of biological macromolecules in solution. Reports Progress in Physics 66, 1735-1782.

Tamburi, N. E. (2009). Efecto de la disponibilidad trófica sobre el ciclo vital y la morfología de Pomacea canaliculata (Caenogastropoda: Ampullariidae). Tesis doctoral, Universidad Nacional del Sur, Bahía Blanca, Argentina.

Tamburi, N. E. \& Martín, P. R. (2009a). Feeding rates and food conversion afficiencies of the apple snail Pomacea canaliculata (Caenogastropoda: Ampullariidae). Malacologia 51, 221-232.

Tamburi, N. E. \& Martín, P. R. (2009b). Reaction norms of size and age at maturity of Pomacea canaliculata (Gastropoda: Ampullariidae) under a gradient of food deprivation. J. Mollus. Stud. 75, 19-26. 
Tamburi, N. E. \& Martín, P. R. (2011). Effect of food availability on reproductive output, offspring quality and reproductive efficiency in the apple snail Pomacea canaliculata. En revisión.

Tehei, M., Madern, D., Franzetti, B., \& Zaccai, G. (2005). Neutron scattering reveals the dynamic basis of protein adaptation to extreme temperature. J. Biol. Chem. 280, 40974-40979.

Teles, R. C., Calderon, L. A., Medrano, F. J., Barbosa, J. A., Guimaraes, B. G., Santoro, M. M. , \& de Freitas, S. M. (2005). pH dependence thermal stability of a chymotrypsin inhibitor from Schizolobium parahyba seeds. Biophys. J. 88, 3509-3517.

Terlau, H. \& Olivera, B. M. (2004). Conus venoms: a rich source of novel ion channel-targeted peptides. Physiol. Rev. 84, 41-68.

Towbin, H., Staehelin, T., \& Gordon J (1977). Electrophoretic transfer of proteins from polyacrylamide gels to nitrocellulose sheets: procedure and some applications. Proc. Natl. Acad. Sci. USA 76, 4350-4354.

Van Handel, E. (1965). Estimation of glycogen in small amounts of tissue. Anal. Biochem. 11, 256-265.

Varki, A. \& Lowe, J. B. (2009). Essentials of Glycobiology, edited by A. Varki, R. D. Cummings, J. D. Esko, H. H. Freeze, P. Stanley, C. S. Bertozzi, G. W. Hart, \& M. E. Etzler, pp. 75-89. New York: Cold Spring Harbor Laboratory Press.

Vasconcelos, I. M. \& Oliveira, J. T. (2004). Antinutritional properties of plant lectins. Toxicon 44, 385-403.

Volkov, V. V. \& Svergun, D. I. (2003). Uniqueness of ab initio shape determination in small-angle scattering. J. Appl. Cryst. 36, 860-864.

Wermeling, D. P. (2005). Ziconotide, an intrathecally administered N-type calcium channel antagonist for the treatment of chronic pain. Pharmacotherapy 25, 1084-1094.

Wernyj, R. P., Mattson, M. P.. \& Christakos, S. (1999). Expression of calbindin-D28k in C6 glial cells stabilizes intracellular calcium levels and protects against apoptosis induced by calcium ionophore and amyloid beta-peptide. Brain Res. Mol. Brain Res. 64, 69-79. 
West, D. J., Andrews, E. B., Bowman, D., McVean, A. R., \& Thorndyke, M. C. (1996). Toxins from some poisonous and venomous marine snails. Review. Comp. Biochem. Physiol. 113C, 1-10.

Williams, B. L., Hanifin, C. T., Brodie, E. D., Jr., \& Caldwell, R. L. (2011). Ontogeny of Tetrodotoxin Levels in Blue-ringed Octopuses: Maternal Investment and Apparent Independent Production in Offspring of Hapalochlaena lunulata. $J$. Chem. Ecol. 37, 10-17, doi:10.1007/s10886-010-9901-4 [doi].

Wingate, V. P., Broadway, R. M., \& Ryan, C. A. (1989). Isolation and characterization of a novel, developmentally regulated proteinase inhibitor $I$ protein and CDNA from the fruit of a wild species of tomato. J. Biol. Chem. 264, 17734-17738.

Yamamoto, T., Carr, P. A., Baimbridge, K. G., \& Nagy, J. I. (1989). Parvalbumin- and calbindin D28k-immunoreactive neurons in the superficial layers of the spinal cord dorsal horn of rat. Brain Res. Bull. 23, 493-508.

Yamazaki, M. (1993). Antitumor and antimicrobial glycoproteins from sea hares. Comp. Biochem. Physiol. C 105, 141-146.

Yamazaki, M., Kisugi, J., Kamiya, H., Kimura, S., \& Mizuno, D. (1985). Purification of antineoplasic factor from eggs of a sea hare. FEBS Lett. 185, 298.

Yoshida, S., Senba, E., Kubota, Y., Hagihira, S., Yoshiya, I., Emson, P. C., \& Tohyama, M. (1990). Calcium-binding proteins calbindin and parvalbumin in the superficial dorsal horn of the rat spinal cord. Neuroscience 37, 839-848.

Yusa, Y. (2001). Predation on eggs of the apple snail Pomacea canaliculata (Gastropoda: Ampullariidae) by the fire ant Solenopsis geminata. J. Mollus. Stud. 67, 275-279.

Yusa, Y. (2004). Inheritance of colour polymorphism and the pattern of sperm competition in the apple snail Pomacea canaliculata (Gastropoda: Ampullariidae). $J$. Mollus. Stud. 70, 43-48.

Yusa, Y., Sugiura, N., \& Ichinose, K. (2000). Predation on the apple snail, Pomacea canaliculata (Ampullariidae), by the Norway rat, Rattus norvegicus, in the field. Veliger 43, 349-353. 
Yusa, Y., Sugiura, N., \& Wada, T. (2006). Predatory potential of freshwater animals on an invasive agricultural pest, the apple snail Pomacea canaliculata (Gastropoda: Ampullariidae), in Southern Japan. Biological Invasions 8, 137-147.

Zavala, J. \& Baldwin, I. T. (2004). Fitness benefits of trypsin proteinase inhibitor expression in Nicotiana attenuata are greater than their costs when plants are attacked. BMC. Ecology 4, 11. 
Tesis Frassa .-2011-. 